\title{
Demand and experiences with financial products and services in climate smart villages
}

Authors: Groot ${ }^{1}$, A., O. van Steenis ${ }^{1}$, W. Jans ${ }^{1}$, J.S. Bolt ${ }^{1}$, J. Recha², P Kimeli ${ }^{2}$, M. Radeny ${ }^{2}$, O. Muhimbo ${ }^{3}$, E. Osmond, D. Kitondo ${ }^{4}$, D. Martinez Baron ${ }^{5}$, V. Santacruz ${ }^{6}$, A. Khatri-Chhetri7, M. Jat ${ }^{7}$, P. Aggarwal ${ }^{7}$, N. Chanana ${ }^{8}$ A. Pant ${ }^{8}$, P. Phuong Thanh ${ }^{9}$, N. Dinh Tien ${ }^{10}$, J. Korner ${ }^{11}$, L. Sebastiaan ${ }^{12}$, M. Ouedraogo ${ }^{13}$, R. Zougmore ${ }^{13}$, A. Dieng ${ }^{14}$, B. Nyour ${ }^{15}$, H. Ibrahim ${ }^{15}$, P. Maalong-Gae ${ }^{15}$, T. Bawa ${ }^{16}$, M. DIOP ${ }^{17}$, Long, $\mathrm{T}^{18}$, Van Asseldonk ${ }^{19}$, M. and C. J. Wattel ${ }^{19}$

\footnotetext{
1 Institute: Wageningen Environmental Research, Wageningen University and Research, the Netherlands

2 Institute: International Livestock Research Institute (ILRI), Kenya

3. Ministry of Agriculture and Cooperatives, Tanzania

4. North Eastern Community Development Programme, Kenya

5. Centro Internacional de Agricultura Tropical (CIAT), Cali - Colombia

6. Fundación Ecohabitats

7. International Maize and Wheat Improvement Center (CIMMYT)-India

8. CCAFS South Asia

9. Vietnam Institute of Fisheries Economics and Planning (VIFEP)

10. Vietnam National University of Agriculture (VNUA)

11. International Center for Tropical Agriculture (CIAT), Vietnam

12. International Rice Research Institute (IRRI) -Vietnam

13. International Crops Research Institute for the Semi-Arid Tropics, Mali

14. Centre National de Recherche Forestière, Senegal

15. Council for Scientific and Industrial Research - Savanna Agricultural Research Institute, Ghana

16. CCAFS, West Africa

17. Institut Sénégalais de Recherches Agricoles

18. Management Studies, Wageningen University, the Netherlands

19. Wageningen Economic Research, Wageningen, the Netherlands
}

Wageningen Environmental Research

Wageningen, January 2018 
Groot, A., O. van Steenis, W. Jans, J.S. Bolt, J. Recha, P Kimeli, M. Radeny, O. Muhimbo, E. Osmond, D. Kitondo, D. Martinez Baron, V. Santacruz, A. Khatri-Chhetri, M. Jat, P. Aggarwal, N. Chanana, A. Pant, P. Phuong Thanh, N. Dinh Tien, J. Korner, L. Sebastiaan, M. Ouedraogo, R. Zougmore, A. Dieng, B. Nyour, H. Ibrahim, P. Maalong-Gae, T.Bawa, M. DIOP, Long, T, Van Asseldonk, M. and C.J. Wattel, 2018. Demand and experiences with financial products and services. Wageningen, Wageningen Environmental Research, the Netherlands, Climate Change, Agricultural Food Security.

Keywords: Climate Smart Agriculture, Scaling, Financial Products, Financial Services

This research was funded by the CCAFS programme

The pdf file is free of charge and can be downloaded at https://doi.org/10.18174/454026.

(C) 2018 Wageningen Environmental Research (an institute under the auspices of the Stichting Wageningen Research), P.O. Box 47, 6700 AA Wageningen, The Netherlands, T +31 (0)317 4807 00, E info.alterra@wur.nl, www.wur.nl/environmental-research. Wageningen Environmental Research is part of Wageningen University \& Research.

- Acquisition, duplication and transmission of this publication is permitted with clear acknowledgement of the source.

- Acquisition, duplication and transmission is not permitted for commercial purposes and/or monetary gain.

- Acquisition, duplication and transmission is not permitted of any parts of this publication for which the copyrights clearly rest with other parties and/or are reserved.

Wageningen Environmental Research assumes no liability for any losses resulting from the use of the research results or recommendations in this report. 


\section{Contents}

$\begin{array}{ll}\text { Summary } & 5\end{array}$

1.

$\begin{array}{ll}\text { Introduction } & 7\end{array}$

$\begin{array}{lll}1.1 & \text { Context and objectives } & 7\end{array}$

1.2 Finance to support adoption of Climate Smart Agriculture $\quad 8$

$\begin{array}{lll}1.3 & \text { Structure of document } & 8\end{array}$

2

$\begin{array}{lr}\text { Methodology } & 9\end{array}$

3

$\begin{array}{ll}\text { Results } & 12\end{array}$

3.1 Availability of and access to financial service providers 12

3.1.1 Financial service providers for making payments 12

$\begin{array}{ll}3.1 .2 \text { Savings } & 13\end{array}$

$\begin{array}{ll}3.1 .3 \text { Credit } & 14\end{array}$

3.1.4 Insurance $\quad 15$

3.1.5 Important information sources on financial products and services $\quad 15$

3.1.6 Strategies to overcome financial losses 16

3.2 Use of financial institutions, products and services $\quad 17$

3.2.1 Financial institutions and their use 17

3.2.2 Credit sources and allocation $\quad 21$

$\begin{array}{lll}3.3 & \text { Climate smart agriculture and investments } & 25\end{array}$

3.3.1 Soil conservation and land preparation $\quad 25$

3.3.2 Water use efficiency or water conservation technologies and practices 26

3.3.3 Weather forecasting services and/or index based insurance 27

3.3.4 Nutrient management technologies and practices 28

3.3.5 Other climate smart technology or practice? (e.g. agro forestry, livestock management) 30

4.1 Preliminary insights into demand and experiences with financial products and services'

4.2 General conclusions $\quad 34$

$\begin{array}{lll}4.3 & \text { Critical issues and future perspectives } & 36\end{array}$

Annex 1 Granted projects Food \& Business Global Challenges Programme (CCAFS) 38

Annex 2 Survey results (part 1)

Annex 3 Survey results (part 2-Climate Smart Agriculture and Investments)50

Annex 4 Questionnaire 


\section{Summary}

This study 'Demand for and experiences with financial products and services' describes and discusses the results of a survey to provide a first insight into the financial services that the smallholder farmers from climate smart villages use and to explore how these are related to climate smart agricultural technologies \& practices. The study is one of three preliminary studies of a multi-year international research project (2016-2022) on 'Business models, incentives and innovative finance for scaling climate smart agriculture (CSA)'. The knowledge and insights developed are used to further support ongoing and emerging climate smart projects in which CCAFS is involved.

A survey was conducted to identify smallholder farmers and the small to medium enterprises (in different stages of the value chain) and their demand for and experiences with financial products and services. There were 148 respondents from 24 villages from Latin America, West Africa, East Africa, Southeast Asia and South Asia. The targeted number of female respondents (50\%) was nog met in all regions, for example in India where the role of female farmers in irrigated agriculture would be limited. A limitation to the results is that in different regions a different number of villages was involved, making it more difficult to generalise results. Sometimes it would prove challenging to make conclusions about the reasoning behind the answers. The study is about adoption climate smart agriculture, but does not define the extent of adoption.

Some preliminary finds are:

- Farmers in the CCAFS regions make use of different financial service providers. Banks are relatively more frequently in use in India and Southeast Asia, Mobile Money transfer more in East and west Africa and in Latin America farmers predominantly use the post office for making payments.

- Banks are becoming more important for saving purposes in all regions except for India where farmers more frequently use SACCOs. Banks are used for saving by both male and female farmers. For Indian female farmers traders are important for saving money.

- In Latin America and India, banks and insurance companies are most popular in obtaining insurance, in Africa and Southeast Asia financial service providers are hardly approached for insurances.

- Training, self-learning, government extension services, farmers associations, SACCOs, family and friends appear to be frequently used strategies and sources for learning about financial products and services.

- In East and West Africa selling livestock of crops to overcome financial losses appear to be a frequently used strategy in overcoming finance losses due to e.g. a bad harvest or illness in the family. Borrowing money from family and friends is a popular strategy for women in Latin America.

Overall most of the farmers applying CSA practices $(77 \%)$, invested either very small amounts (< US\$ 100 ) or nothing at all. Perhaps CSA practices do not require more investments, or farmers would have liked to invest more but were not able to or prioritised other investments or expenditures. The use of financing through banks is quite high.

More than half of the farmers was able to finance the CSA practices themselves, either by self-financing, or by selling assets, using remittance funds or drawing from their VSLA or merry-go-round. Approximately $8 \%$ financed it through financial institutions (banks, MFIs, SACCOs) and $14 \%$ from trade-related sources (traders, shopkeepers, ESSOKO, savings collectors).

The differences in financial profiles between individual practices seem more significant than the differences between types of practices. Furthermore the influence of specific context is quite strong (location, available services and institutional infrastructure). 
The main suggestions from the farmers, in order to enhance the application of CSA practices are in order of number of responses:

- Improvements to the financial product (18\%): the most frequent suggestion is to have lower interest rates or soft loans, other suggestions relate to changes in the credit product (credit in kind, more flexible loans, higher amounts, easier access.

- Subsidies (11\%): the suggestions range from free weather forecasts, to subsidies for fertilizer and manure, or for adaptation measures.

- Training (9\%): either generic or on specific issues as irrigation, awareness creation of financial services.

- Other services: for example more location-specific and language-specific weather forecasts, or tractor services or market information. These suggestions are not as generalized as the other suggestions mentioned in the previous points.

The survey also revealed diverse critical issues in the access, awareness and use of financial services and products

- Interest rate: although not a primary focus, a relatively high percentage of respondents suggest lower interest rates to facilitate climate smart technologies and practices. We suggest to consider improving the understanding of diversity in credit for single and layered use of climate smart technologies and practices.

- Training: all respondents are linked with the CCAFS programme, explaining the high rate received trainings in climate smart technologies and practices. The percentage of training in financial products and services or business development was much lower. We suggest a selection of case studies/support informed by opportunities to include capacity building of smallholder farmers (for the use of financial products, services and business development), managers of financial institutes in climate change and CSA related risks on investments, and to develop and test training/capacity building material

- Insight into costs and benefits of CSA technologies and practices: Formal and informal financial institutions as well as farmers wanting to borrow money for investing in CSA technologies and practices need to be aware of the involved added value and involved risks.

For the selection of future cases and/or support of the granted projects in the call of the Food \& Business Global Challenges Programme, we suggest to select cases and/or support projects where in addition to knowledge generation on financial products and services, insights into (economic /social) costs and benefits of climate smart agriculture technologies and practices will be developed as well. 


\section{Introduction}

\subsection{Context and objectives}

The present study 'Demand for and experiences with financial products and services' describes and discusses the results of a survey, which was carried out to develop first insight into the financial services that the smallholder farmers actually use and to explore how these are related to climate smart agricultural technologies \& practices.

The study is one of the preliminary studies of a multi-year international research project (2016-2022) on 'Business models, incentives and innovative finance for scaling climate smart agriculture (CSA)'. This project is part of the so-called Flagship 2 on Climate smart Technologies and Practices of the CGIAR Research Program on Climate Change, Agriculture and Food Security (CCAFS). This project explores the role of finance in combination with business models and competence building to support smallholder farmers and Small to Medium Enterprises (SMEs) to adopt CSA. Specifically, this projects aims to develop context-specific knowledge on the factors and conditions, which constitute an effective technical and financial package to scale climate smart agriculture.

At the start of the project in 2017, three preliminary studies were carried out simultaneously:

1. An inventory of potential profitable and scalable CSA business cases in the CCAFS Priority areas;

2. A survey 'Understanding the demand for financial products and services in CSA in the CCAFS priority areas';

3. Mapping of the supply of financial services (Wattel \& van Asseldonk, 2017).

The knowledge and insights developed in these activities are used to further support ongoing and emerging climate smart projects in which CCAFS is involved. Specifically, the three studies enable the research team to support the granted projects in the call of the Food \& Business Global Challenges Programme (2017), a collaboration between the CGIAR Research Program on Climate Change, Agriculture and Food Security (CCAFS) and the Dutch Food \& Business Knowledge Platform and NWO-WOTRO Science for Global Development (Annex 1). These projects focus on new business models for scaling CSA at the local level; explore innovative value-chain based incentive mechanisms for CSA adoption; explore emerging innovative finance instruments that support CSA scaling up and/or improve the enabling conditions for scaling up. All granted projects are located in East Africa.

The present study 'Demand for and experiences with financial products and services' has a signalling character. The survey aims to:

- Generate first insights into the financial products and services that the smallholder farmers actually use and how these are related to CSA technologies \& practices.

- Identify critical issues in the access and use of financial products and services that enable or hinder the uptake of climate smart technologies and practices.

The critical issues will inform future decisions on selection of case studies and support to the granted projects in the call of the Food \& Business Global Challenges Programme. 


\subsection{Finance to support adoption of Climate Smart Agriculture}

Agriculture faces the enormous challenge of feeding the world's growing population. Although crop yields have grown impressively in the last few decades, production requires an increase by another $60-70 \%$ by 2050 to meet the demand (Grist 2015). Climate change poses additional challenges to agriculture, particularly in developing countries. Climate Smart Agriculture (CSA) aims to respond to these challenges. It represents a strategy that can help increasing farmers' resilience to weather extremes, adapting to climate change and climate variability, while decreasing agriculture's greenhouse gas (GHG) emissions that contribute to global warming (Steenwerth et al., 2014). Over the last decade, considerable CSA research has been conducted on farming practices and technologies for mitigation of agricultural GHG emissions and for adaptation of farming systems to new climate conditions (Steenwerth et al., 2014). However, many climate smart technologies and practices are still not achieving their full potential impact because of low levels of adoption by smallholder farmers. There are many plausible reasons for this, including hindering institutions and policies, constraints related to the natural system, market uncertainty, cultural constraints, our limited understanding about smallholder farmers' decision making, and insufficient access to sufficient and adequate finance (Long et al., 2015; Westermann et al., 2014).

The present study addresses the issue of access to sufficient and adequate finance. In particular, it seeks to better understand the demand for finance to be able to adopt CSA technologies \& practices. This understanding, in combination with insight into the supply side of financial products (e.g. Wattel and van Asseldonk, 2017), is critical to designing policies, and public and private financial products and services to catalyse the uptake of CSA technologies \& practices and as such the scaling of CSA.

The demand side entails private enterprises in the real economy. This study focusses on the demand of small farmers and SMEs for financial products and services in the CCAFS regions (Latin America, South Asia, Southeast Asia, West Africa and East Africa). Small farmers are searching for finance to invest in adaptation measures to reduce physical climate risks, reduce costs and/or increase revenues. Likewise, SMEs (service providers) are in need of finance to invest CSA to capitalise on a new business opportunity that has arisen as a result of climate change.

\subsection{Structure of document}

This report is organised as follows. Chapter 2 describes the methodology and highlights the setup of the survey and types of questions used. In chapter 3, the results of the study are presented. Chapter 4 concludes and provides recommendations for the selection of case studies and type of support to the granted projects in the call of the Food \& Business Global Challenges Programme /CCAFS in the next phase of the project. 


\section{Methodology}

Taking into account the objectives of the inventory and the diversity of the regions and countries in which the CCAFS programme is engaged, a rather practical and explorative approach was adopted for this study. The inventory was based on the following aspects:

\section{Focus on promising and scalable business cases for CSA in CCAFS priority areas}

The present study focussed on finance supporting (or hindering) the uptake of CSA technologies and practices that are economically and socially sustainable. Building upon the results of the first 'inventory of potential profitable and scalable CSA business cases in CCAFS priority areas', the coordinators of the CCAFS regions selected 1-2 promising and scalable cases to carry out the second inventory 'Demand for and experiences with financial products and services'. This inventory covered the five regions were CCAFS is engaged: Latin America, South Asia, Southeast Asia, West Africa and East Africa. The CCAFS priority areas are so-called Climate Smart Villages (CSVs) where CCAFS and local partners are working with smallholder farmers, SMEs and other stakeholders to improve their climate resilience. All these villages are in high-risk areas, which will likely suffer most from a changing climate.

\section{Questionnaire}

A questionnaire (Annex 4) was used to identify smallholder farmers' and SMEs' demand for and experiences with financial products and services' in these promising and scalable cases. This method was adopted as it enables to conduct an inventory in a relatively short time and fits the signalling character of the study. The research team provided the CCAFS regional coordinators with a web-based version of the questionnaire. The CCAFS regional coordinators organised the implementation of the inventory in the field with the help of local partners. These partners used a hard copy of the questionnaire to carry out face-to-face interviews with respondents.

For each of the selected promising case study, a minimum of 15 interviews were to be conducted with the use of the questionnaire. Respondents of the questionnaire included: 1) female and male smallholder farmers(at least $50 \%$ of the respondents were to be female farmers), and 2) SMEs involved in different stages of the value chain (e.g. service providers, input suppliers). At least $25 \%$ of the respondents were to be (women-led) SMEs such as traders and input suppliers. Table 1 shows the total number of interviews conducted in the different regions (and countries), including the number of female and male respondents and SMEs.

\section{Pre-testing}

Draft versions of the questionnaire were shared with the CCAFS regional coordinators who provided feedback and made suggestions for improvements. The first full version was pre-tested on the basis of five interviews in all CCAFS regions. The pre-test identified questions that did not make sense to respondents and suggested a few additional questions.

\section{Analysis}

Answers of respondents were incorporated in a digital version of the questionnaire. The data were transformed into spreadsheets and analysed with Microsoft Excel. The analysis of the results mainly highlight the most frequently cited results, differences in use and experiences with financial products and services between CCAFS regions, and between men and women. 


\section{Limitations}

The study has the following limitations:

- The required percentage of female respondents was not met in all CCAFS regions. In Haryana (India) the role of female farmers in irrigated agriculture in the climate smart village 'Karnal' is limited;

- According to the results, in Vietnam and Tanzania no SMEs were interviewed. Maybe the term SME was not well understood. Therefore SMEs were not taken as separate user category in the analysis;

Table 1: Survey - countries, states, departments, villages, CSA activities and number of interviews

\begin{tabular}{|c|c|c|c|c|c|}
\hline Country - State & Villages & $\begin{array}{l}\text { Promising business case } \\
\text { for scaling CSA }\end{array}$ & $\begin{array}{l}\text { No. male } \\
\text { interv. }\end{array}$ & $\begin{array}{l}\text { No. female } \\
\text { interv. }\end{array}$ & $\begin{array}{l}\text { Total } \\
\text { No. } \\
\text { interv } \\
\text { iews }\end{array}$ \\
\hline \multicolumn{6}{|l|}{ Latin America } \\
\hline Colombia | Cauca & $\begin{array}{l}\text { 1. CSV Noroccidente de } \\
\text { Popayán-Cauca }\end{array}$ & $\begin{array}{l}\text { Pest resistant varieties } \\
\text { and management }\end{array}$ & 2 & 12 & 14 \\
\hline \multicolumn{6}{|l|}{ West Africa } \\
\hline Senegal | Kaffrine & $\begin{array}{l}\text { 1. Daga Birame } \\
\text { 2. Ngouye Kahi }\end{array}$ & $\begin{array}{l}\text { Climate information } \\
\text { through PICSA approach } \\
\text { Non timber forest products }\end{array}$ & $\begin{array}{l}20 \text { male } \\
\text { (incl. } 1 \text { SME) }\end{array}$ & $\begin{array}{l}15 \text { female } \\
\text { (incl. } 1 \mathrm{SME} \text { ) }\end{array}$ & 35 \\
\hline $\begin{array}{l}\text { Ghana I } \\
\text { Upper West }\end{array}$ & $\begin{array}{ll}\text { 1. } & \text { Bompari (Lawra) } \\
\text { 2. } & \text { Dazuuri (Lawra) } \\
\text { 3. } & \text { Daggoh (Jirapa) }\end{array}$ & $\begin{array}{l}\text { Climate information } \\
\text { through PICSA approach }\end{array}$ & $\begin{array}{l}22 \text { male } \\
\text { (incl. } 5 \text { SME) }\end{array}$ & $\begin{array}{l}9 \\
\text { female(incl. } \\
3 \text { SME) }\end{array}$ & 31 \\
\hline & & & $\begin{array}{l}42 \\
\text { (6 SME) }\end{array}$ & $\begin{array}{l}24 \\
(4 \text { SME) }\end{array}$ & 66 \\
\hline \multicolumn{6}{|l|}{ East Africa } \\
\hline Kenya | Rift Valley & $\begin{array}{ll}\text { 1. } & \text { Chemilpagei (Kericho) } \\
\text { 2. Kaborok Kericho) } \\
\text { 3. Kapsorok (kericho) }\end{array}$ & $\begin{array}{l}\text { Improved ruminant breed } \\
\text { varieties and soil } \\
\text { management }\end{array}$ & $\begin{array}{l}5 \text { male } \\
\text { (5 SME) }\end{array}$ & $\begin{array}{l}1 \text { female } \\
(1 \mathrm{SME})\end{array}$ & 6 \\
\hline Kenya | Nyanza & $\begin{array}{ll}\text { 1. } & \text { Kasaye (Kisumu) } \\
\text { 2. } & \text { Kamuana (Kisumu) } \\
\text { 3. } & \text { Lower Kamula (Kisumu }\end{array}$ & $\begin{array}{l}\text { Introduction of Sorghum } \\
\text { varieties and soil } \\
\text { management }\end{array}$ & $\begin{array}{l}9 \text { male } \\
\text { (incl. } 5 \text { SME) }\end{array}$ & $\begin{array}{l}5 \text { female } \\
\text { (incl. } 2 \text { SME) }\end{array}$ & 14 \\
\hline Tanzania | Tanga & $\begin{array}{ll}\text { 1. } & \text { Boheloi (Lushoto) } \\
\text { 2. } & \text { Kwekitui (Lushoto) } \\
\text { 3. } & \text { Kwesine (Lushoto) }\end{array}$ & $\begin{array}{l}\text { Improved potato varieties } \\
\text { and soil management }\end{array}$ & 7 male & 3 female & 10 \\
\hline $\begin{array}{l}\text { Tanzania | } \\
\text { Milungui Migambo }\end{array}$ & 1. Migambo (Lushoto) & $\begin{array}{l}\text { Improved potato varieties } \\
\text { and soil management }\end{array}$ & 4 male & 1 female & 5 \\
\hline & & & $\begin{array}{l}25 \\
(10 \text { SME) }\end{array}$ & $\begin{array}{l}10 \\
\text { (3 SME) }\end{array}$ & 35 \\
\hline \multicolumn{6}{|l|}{ Southeast Asia } \\
\hline $\begin{array}{l}\text { Vietnam I } \\
\text { Thanh Hoa }\end{array}$ & $\begin{array}{l}\text { 1. Hoang Phong } \\
\text { 2. Bac Hai village, Hoang } \\
\text { Phong commune } \\
\text { 3. Lien son village - } \\
\text { Hoang Phong commune } \\
\text { 4. Trung trieu village - } \\
\text { Hoang Pong Commune }\end{array}$ & $\begin{array}{l}\text { Aquaculture farming for } \\
\text { livelihoods and food } \\
\text { security }\end{array}$ & 10 male & 5 female & 15 \\
\hline \multicolumn{6}{|l|}{ South Asia } \\
\hline India | Haryana & $\begin{array}{ll}\text { 1. } & \text { Chorpura } \\
\text { 2. } & \text { Dabkoli } \\
\text { 3. } & \text { Geer } \\
\text { 4. } & \text { Bastada }\end{array}$ & $\begin{array}{l}\text { ICT and machinery } \\
\text { provision }\end{array}$ & $\begin{array}{l}14 \text { males } \\
\text { (incl. } 2 \text { SME) }\end{array}$ & $\begin{array}{l}4 \text { females } \\
\text { (incl. } 1 \mathrm{SME} \text { ) }\end{array}$ & 18 \\
\hline In total & $\underline{24 \text { villages }}$ & & $\begin{array}{l}\underline{93} \\
18 \text { SME }\end{array}$ & $\begin{array}{l}\underline{55} \\
8 \text { SME }\end{array}$ & $\underline{148}$ \\
\hline
\end{tabular}

- Only in the regions West and East Africa, interviews were conducted in more than one country. Therefore the relevance of comparing results between countries within one single region was limited;

- Some questions permitted the option 'not applicable' as answer. For questions like those on loans, this option scored relatively high, partly because a relatively large number of respondents did not obtain any loan. However, there might be other reasons why the questions were not applicable. These reasons are not known; 
- The setup of questionnaire appeared not to allow conclusions about the reasons behind differences in interest rates between regions and between men and women. The issue of (differences in) interest rates should have been addressed with the use of open question;

- The questionnaires focus on adoption of climate smart agriculture but do not further detail the extent of adoption (for example if it is applied on the whole farm, or just in part or to what extent the inputs achieve the recommended levels) which may be constrained by limited credit;

- This is a small study within a wide diversity of contexts across nations and CSA practices where both farmers and SMEs are considered. 


\section{Results}

The result section largely follows the setup of the survey and is organised in three parts:

1. Availability of and access to financial service providers presenting respondents' reaction to questions concerning:

- Financial services for making payments;

- Financial services for savings, financial services for obtaining credit;

- Financial services for insurance; and,

- Information sources to improve their knowledge on financial products and services.

2. Use of and experience with financial products and services presenting respondents' answers to questions concerning:
a. (Use of) Bank account;
b. (Use of) financial credit;
c. Credit sources and allocation.

3. Climate smart agriculture and investments

Detailed results on these three sections are presented in Annexes 2 and 3. The sections respondents identification details' and 'general characteristics of farm household' are partly incorporated in the methodology section.

\subsection{Availability of and access to financial service providers}

\subsubsection{Financial service providers for making payments}

The results indicate that the majority of respondents in the five CCAFS regions are aware and have access to financial services for making payments. Figure 1 shows that in East Africa the Majority (97\%) of the respondents transfer money through mobile money services, whereas in Latin America the majority $(82 \%)$ use the post office. West African respondents pointed out that they predominantly $(57 \%)$ make use of mobile money services and, to a lesser extent, of a bank (32\%). In India (S Asia), most respondents (53\%) transfer money through the State Bank of India, the Punjab National bank or the Oriental Bank of Commerce, $41 \%$ revert to family or friends for making payments. The majority of the respondents from Southeast Asia transfer money through banks and informal saving networks. Traders are approached for financial products and services in India only (by $3 \%$ of the interviewees).

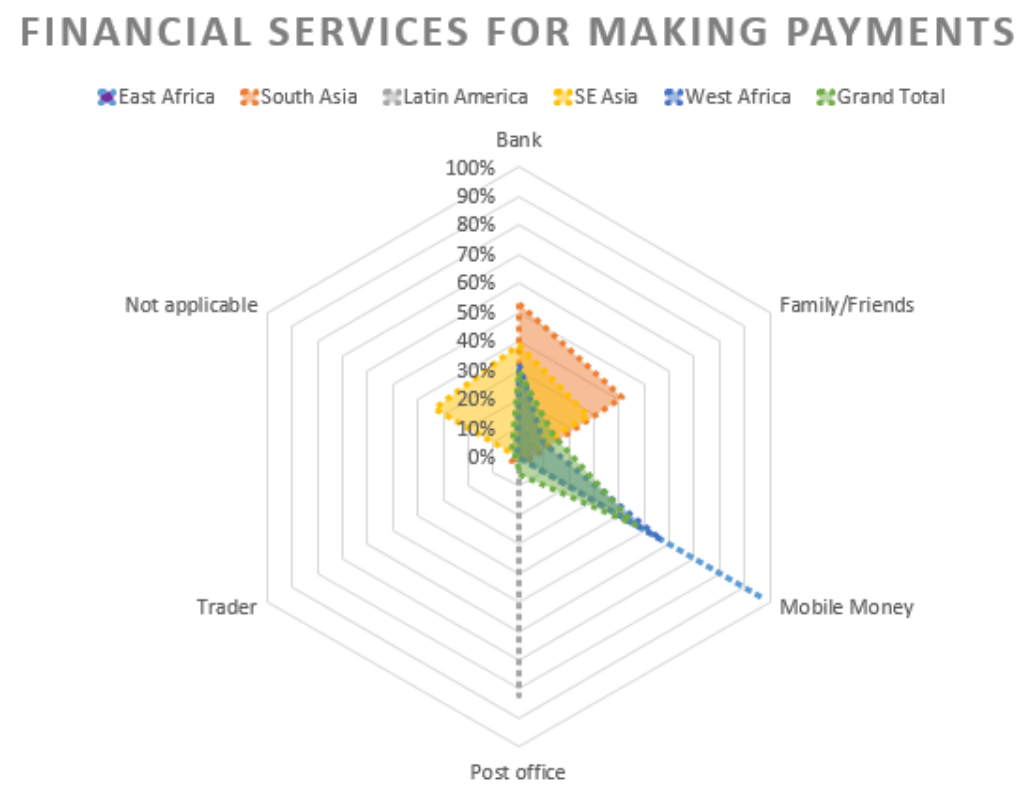

Figure 1: Financial services for making payments 
Table 2 shows the access to financial institutions in use for making payments, disaggregated for gender. In East Africa men and women make almost equally use of mobile money for making payments. In India the majority of respondents using a bank are women. In Latin American women use most frequently the post office for making money transfers. In Southeast Asia, 39\% of the respondents make use of a bank of which $43 \%$ are women and $57 \%$ are men.

Table 2: Financial institutions in use for making payments, disaggregated by gender

\begin{tabular}{|c|c|c|c|c|c|}
\hline & L America & West Africa & $\begin{array}{c}\text { East } \\
\text { Africa }\end{array}$ & SE Asia & South Asia \\
\hline Bank & $12 \%$ & $32 \%$ & $3 \%$ & $39 \%$ & $53 \%$ \\
\hline female & $100 \%$ & $62 \%$ & $100 \%$ & $43 \%$ & $17 \%$ \\
\hline male & $0 \%$ & $38 \%$ & $0 \%$ & $57 \%$ & $83 \%$ \\
\hline Family/Friends & $6 \%$ & $10 \%$ & $0 \%$ & $28 \%$ & $41 \%$ \\
\hline female & $100 \%$ & $62 \%$ & & $20 \%$ & $36 \%$ \\
\hline male & $0 \%$ & $38 \%$ & & $80 \%$ & $64 \%$ \\
\hline Mobile Money & $0 \%$ & $57 \%$ & $97 \%$ & $0 \%$ & $3 \%$ \\
\hline female & & $42 \%$ & $54 \%$ & & $0 \%$ \\
\hline male & & $58 \%$ & $46 \%$ & & $100 \%$ \\
\hline Post office & $82 \%$ & $0 \%$ & $0 \%$ & $0 \%$ & $0 \%$ \\
\hline female & $86 \%$ & & & & \\
\hline male & $14 \%$ & & & & \\
\hline Trader & $0 \%$ & $0 \%$ & $0 \%$ & $0 \%$ & $3 \%$ \\
\hline male & & & & & $100 \%$ \\
\hline Not applicable & $0 \%$ & $1 \%$ & $0 \%$ & $33 \%$ & $0 \%$ \\
\hline female & & $100 \%$ & & $33 \%$ & \\
\hline male & & $0 \%$ & & $67 \%$ & \\
\hline Grand Total & $100 \%$ & $100 \%$ & $100 \%$ & $100 \%$ & $\underline{\underline{100 \%}}$ \\
\hline
\end{tabular}

\subsubsection{Savings}

Banks are important institutions for saving purposes in all regions except from Southeast Asia where farmers use more frequently SACCOs (Savings and Credit Cooperative Organization)(Figure 2). In Latin America and to a lesser extent in India, most of the respondents use a bank for saving purposes. In East Africa $49 \%$ of the interviewees use mobile money services for savings and $31 \%$ a bank. SUSUs (informal loan club) are only used for savings in West Africa. Village Savings and Loan Association (VSLA) are in use by relatively few respondents from East and West Africa.

Table A2.1 (Annex 2) presents the financial sources for saving disaggregated by gender. In East Africa, both men and women make use of banks and mobile money for saving purposes almost equally. In India, amongst those respondents using a bank and family /friends for savings, the majority is men. Indian female farmers use traders for savings. In Latin America, women prefer a bank, cooperative and family/friends for savings. In Southeast Asia, women do not use banks for savings. In West Africa, of the $35 \%$ using banks for saving, $47.5 \%$ are women. $56,25 \%$ of the respondents from Southeast Asia perceived the question as not applicable. It is not clear if this is due to the fact that respondents are not saving or because of other reasons. 


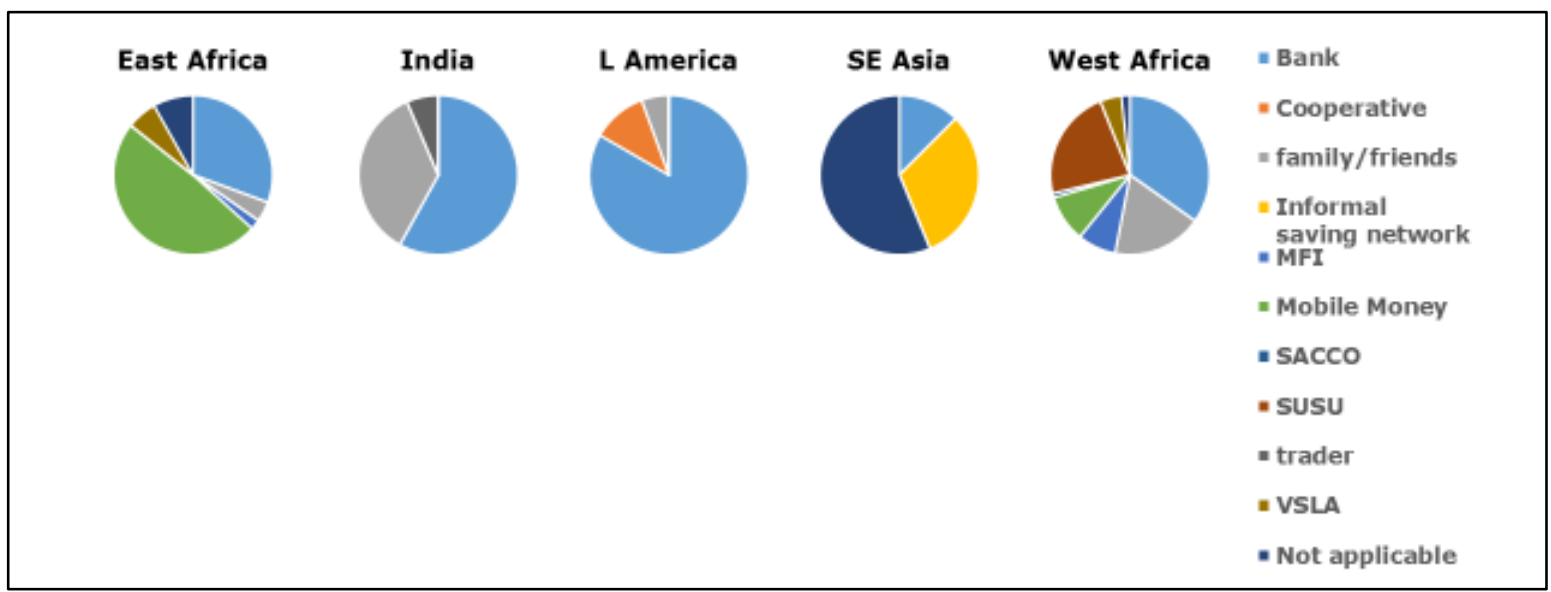

Figure: 2: Services for savings

MFI Micro Financial Institutions

SACCO Savings and Credit Cooperative Organizations

SUSU Method of pooling savings in parts of West Africa and the Caribbean.

VSLA Village Savings and Loan Association

\subsubsection{Credit}

Figure 3 shows financial services used for obtaining a credit/loan. In East Africa, the majority of the respondents (31\%) make use of mobile money services, $17 \%$ of the respondents receive credit from banks and $15 \%$ from a Village Savings and Loan Association. In India, respondents mainly make use of banks $(35.90 \%)$, traders (33\%) and, to a lesser extent, of family or friends $(20.5 \%)$. For respondents in Latin America, banks appear to be popular for receiving credit (82\%). In Southeast Asia, almost $50 \%$ of the respondents obtain a credit from banks and $37.04 \%$ from informal saving networks. In West Africa, the three most frequently used services include family/friends (26\%), banks (25.5\%) and SUSUs (24\%) (Table A2, Annex 2).

For the most frequent used sources for obtaining a credit, East African women use most frequently a mobile money system (Table A2, Annex 2). In India, women go to family, moneylenders and traders to obtain a loan. Amongst those Indian respondents making use of banks for credit all are men. In Latin America out of the $82 \%$ using a bank for loans, $86 \%$ are women. For Southeast Asia, amongst those respondents (48\%) who borrow money from banks, $23 \%$ are women. In West Africa, men make more often use of family /friends for borrowing money than women.

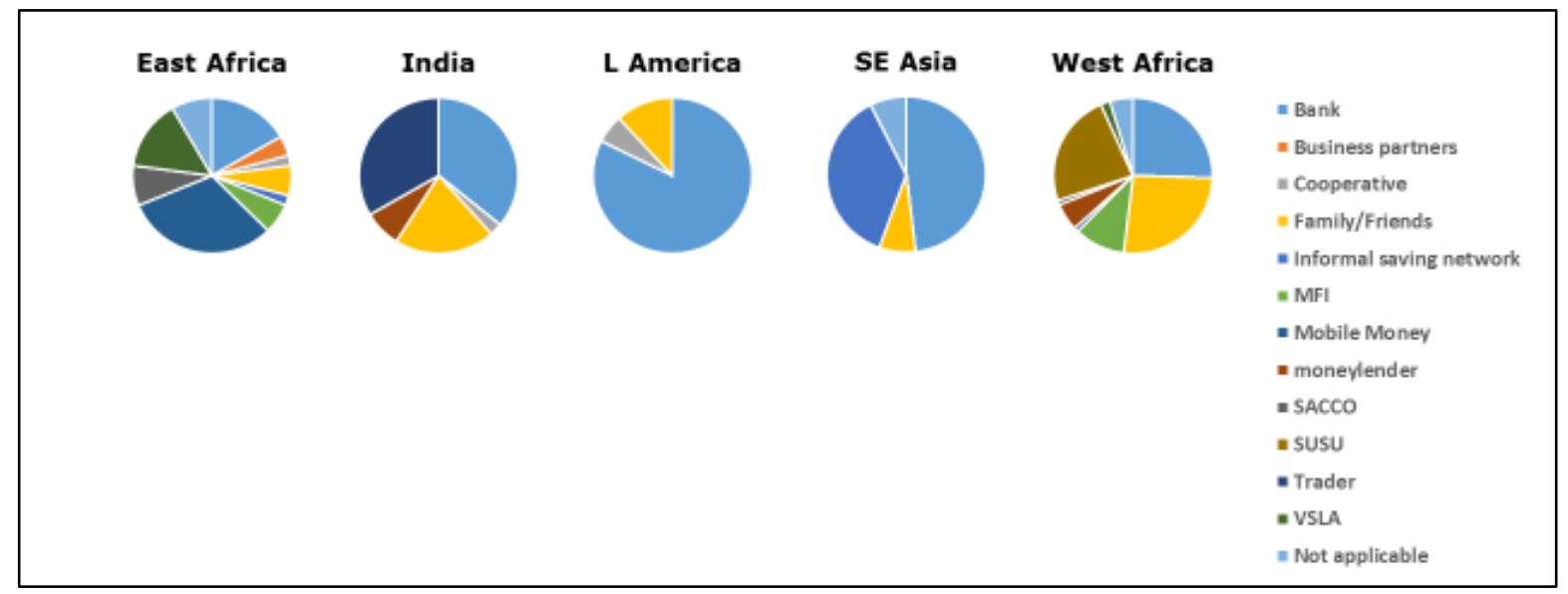

Figure 3: Used services for obtaining credit 


\subsubsection{Insurance}

Figure 4 presents the services from which respondents obtain an insurance such as health insurance or a crop insurance. The option non-applicable scored very high in South Asia ( $80 \%$ of the respondents), in East Africa $46 \%$ of the respondents and in West Africa (41 of the respondents). Insurance agencies appeared to be used in all regions.

For the most frequently, used sources for obtaining an insurance, in East Africa most respondents (27\%) obtain an insurance from a bank, $20 \%$ of whom are women (Table A2.3, Annex 2). In India, banks are used for obtaining insurances by $36 \%$ of the respondents $17 \%$ of whom are women. $33 \%$ of the Latin American respondents obtain an insurance from an insurance company, $80 \%$ of them are women. In West Africa, $38 \%$ of the interviewees also make use of an insurance company, but here $52 \%$ of them are women.

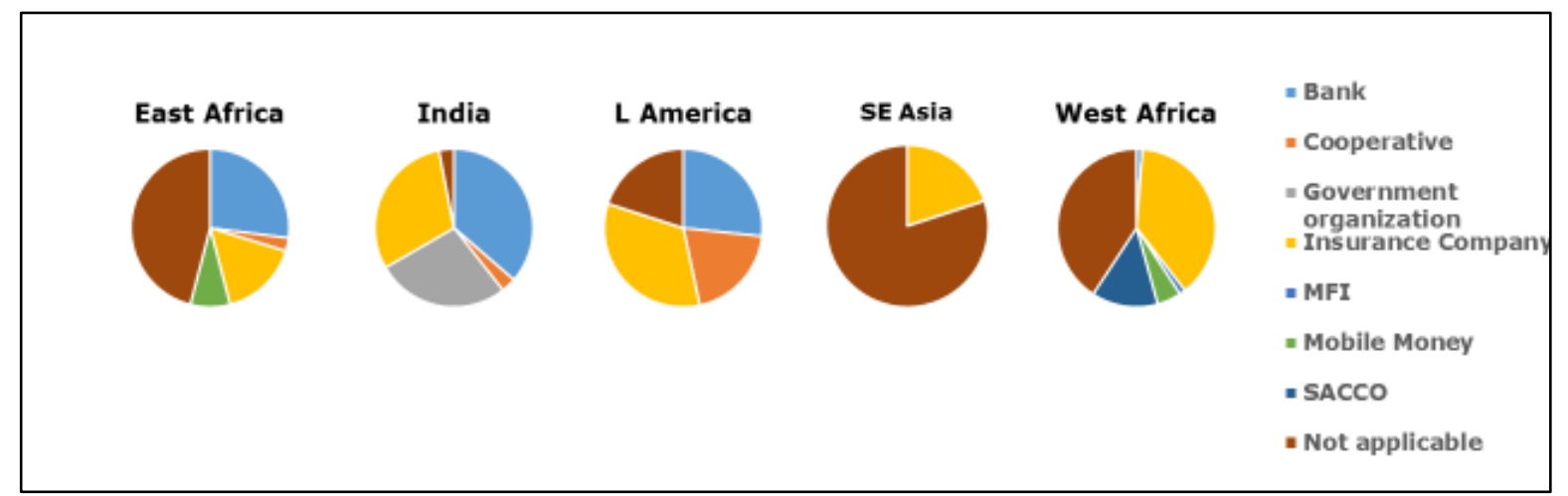

Figure 4: Use of services for insurance

\subsubsection{Important information sources on financial products and services}

Table 3 shows that respondents make use of a variety of information sources to improve their knowledge about financial products and services. Trainings, self-learning, government extension services and farmer associations appear to be sources of information that are most frequently used. 
Table 3: Sources used to improve knowledge about financial products and services

\begin{tabular}{|c|c|c|c|c|c|}
\hline Information sources & East Africa & India & L America & SE Asia & $\begin{array}{l}\text { West } \\
\text { Africa }\end{array}$ \\
\hline Bank & $1 \%$ & $15 \%$ & $0 \%$ & $11 \%$ & $2 \%$ \\
\hline CCAFs Agent & $0 \%$ & $0 \%$ & $0 \%$ & $0 \%$ & $2 \%$ \\
\hline Community members & $2 \%$ & $15 \%$ & $0 \%$ & $6 \%$ & $6 \%$ \\
\hline Development partners & $4 \%$ & $2 \%$ & $0 \%$ & $0 \%$ & $9 \%$ \\
\hline Extension agent & $5 \%$ & $0 \%$ & $0 \%$ & $0 \%$ & $6 \%$ \\
\hline Facilitating agencies & $8 \%$ & $0 \%$ & $39 \%$ & $8 \%$ & $5 \%$ \\
\hline Farmers associations & $8 \%$ & $4 \%$ & $7 \%$ & $17 \%$ & $10 \%$ \\
\hline Friends/Family & $3 \%$ & $17 \%$ & $4 \%$ & $14 \%$ & $10 \%$ \\
\hline $\begin{array}{l}\text { Government extension } \\
\text { services }\end{array}$ & $16 \%$ & $9 \%$ & $0 \%$ & $0 \%$ & $9 \%$ \\
\hline Internet & $1 \%$ & $4 \%$ & $0 \%$ & $0 \%$ & $0 \%$ \\
\hline MFI & $1 \%$ & $0 \%$ & $0 \%$ & $0 \%$ & $1 \%$ \\
\hline News, magazines & $3 \%$ & $9 \%$ & $0 \%$ & $0 \%$ & $0 \%$ \\
\hline Radio & $7 \%$ & $4 \%$ & $0 \%$ & $0 \%$ & $8 \%$ \\
\hline SACCO & $3 \%$ & $0 \%$ & $0 \%$ & $17 \%$ & $0 \%$ \\
\hline Savings \& credit group & $7 \%$ & $0 \%$ & $0 \%$ & $0 \%$ & $2 \%$ \\
\hline School & $0 \%$ & $2 \%$ & $0 \%$ & $0 \%$ & $1 \%$ \\
\hline Self-learning & $6 \%$ & $4 \%$ & $25 \%$ & $22 \%$ & $13 \%$ \\
\hline SMS services & $1 \%$ & $4 \%$ & $0 \%$ & $0 \%$ & $3 \%$ \\
\hline Spouse & $1 \%$ & $2 \%$ & $0 \%$ & $0 \%$ & $1 \%$ \\
\hline Traders/ middlemen & $2 \%$ & $4 \%$ & $0 \%$ & $0 \%$ & $1 \%$ \\
\hline Trainings & $22 \%$ & $0 \%$ & $25 \%$ & $3 \%$ & $9 \%$ \\
\hline Other & $1 \%$ & $4 \%$ & $0 \%$ & $3 \%$ & $0 \%$ \\
\hline Not applicable & $0 \%$ & $0 \%$ & $0 \%$ & $0 \%$ & $2 \%$ \\
\hline Grand Total & $100 \%$ & $100 \%$ & $100 \%$ & $100 \%$ & $100 \%$ \\
\hline
\end{tabular}

Except from India and South Asia, women make more use of self-learning to improve their knowledge than man (Table A2.4, Annex 2). In East Africa government extension services are most frequently used as source of information, but relatively more by men than by women. In East Africa and Latin America, women appear to make relatively more use of trainings as source of learning about financial services and products than men. In India, family and friends appear to be an useful source of information and, to a lesser extent, banks and other community members. In Latin America, especially women consult facilitating agencies (e.g. NGOs) to learn about financial services and products. In Southeast Asia $22.22 \%$ respondents mentioned, they learn about finance all by themselves and $16.67 \%$ of them, both men and women, use SACCOs to gain knowledge about financial products and services. In West Africa, self-learning, farmers associations, friends, and relatives are equally important as information source, both for men and women.

\subsubsection{Strategies to overcome financial losses}

Table 4 presents options respondents use to finance losses due to for example. a bad harvest or illness in the family. Overall, borrowing money from family/friends, credit from a bank and selling livestock or crop are the most frequently used strategies to overcome financial losses. $22.39 \%$ Of the East African respondents pointed out that they will sell livestock or crops to overcome financial losses, $60 \%$ of them are male. 
Table 4: Options in use to overcome finance losses due to e.g. a bad harvest or illness in the family

\begin{tabular}{|c|c|c|c|c|c|c|}
\hline Options & $\begin{array}{c}\mathrm{L} \\
\text { America }\end{array}$ & $\begin{array}{l}\text { West } \\
\text { Africa }\end{array}$ & $\begin{array}{l}\text { East } \\
\text { Africa }\end{array}$ & SE Asia & India & $\begin{array}{l}\text { Grand } \\
\text { Total }\end{array}$ \\
\hline $\begin{array}{l}\text { By borrowing money from a } \\
\text { bank }\end{array}$ & $7 \%$ & $12 \%$ & $19 \%$ & $33 \%$ & $30 \%$ & $18 \%$ \\
\hline $\begin{array}{l}\text { By borrowing money from an } \\
\text { family/friends }\end{array}$ & $86 \%$ & $20 \%$ & $18 \%$ & $19 \%$ & $27 \%$ & $23 \%$ \\
\hline $\begin{array}{l}\text { By borrowing money from } \\
\text { elsewhere, please specify }\end{array}$ & $0 \%$ & $2 \%$ & $4 \%$ & $4 \%$ & $0 \%$ & $3 \%$ \\
\hline By having an insurance & $0 \%$ & $5 \%$ & $4 \%$ & $0 \%$ & $7 \%$ & $4 \%$ \\
\hline By selling livestock or crop & $7 \%$ & $20 \%$ & $22 \%$ & $11 \%$ & $7 \%$ & $17 \%$ \\
\hline $\begin{array}{l}\text { By subsidy or gifts (and by } \\
\text { whom?) }\end{array}$ & $0 \%$ & $2 \%$ & $4 \%$ & $0 \%$ & $0 \%$ & $2 \%$ \\
\hline By taking a temporary job & $0 \%$ & $9 \%$ & $4 \%$ & $0 \%$ & $0 \%$ & $5 \%$ \\
\hline $\begin{array}{l}\text { I am self-supporting and do not } \\
\text { use external finance }\end{array}$ & $0 \%$ & $13 \%$ & $18 \%$ & $19 \%$ & $13 \%$ & $14 \%$ \\
\hline Merry go round & $0 \%$ & $0 \%$ & $0 \%$ & $15 \%$ & $0 \%$ & $2 \%$ \\
\hline Other & $0 \%$ & $15 \%$ & $4 \%$ & $0 \%$ & $3 \%$ & $9 \%$ \\
\hline Trader & $0 \%$ & $0 \%$ & $0 \%$ & $0 \%$ & $13 \%$ & $2 \%$ \\
\hline Not applicable & $0 \%$ & $2 \%$ & $0 \%$ & $0 \%$ & $0 \%$ & $1 \%$ \\
\hline Grand Total & $100 \%$ & $100 \%$ & $100 \%$ & $100 \%$ & $100 \%$ & $100 \%$ \\
\hline
\end{tabular}

In India borrowing money from a bank seems to be the most popular strategy to deal with financial problems, but for men only. The majority of Latin American interviewees $(85.71 \%)$ borrow money from friends and family, especially women. In Southeast Asia, a bank appears to be an important financial safety net, but more frequently used by men than women. In West Africa 'obtaining money by selling livestock or crops' and 'borrowing money from family/friends' appear to be equally important strategies, both for men and women. Though borrowing money from friends and family is a popular strategy, we should consider the fact that family and friends may be affected by the same type of financial losses, especially when due to harvest loss.

\subsection{Use of financial institutions, products and services}

\subsubsection{Financial institutions and their use}

Banks

Figure 5 shows that all Indian respondents have a bank account, whereas in East Africa 48.57\%, in West Africa 33.33\%, in Latin America $85.71 \%$ and in SE Asia $26.67 \%$ of the interviewees have a bank account. For East Africa, $50 \%$ of the female respondents do have a bank account, in India 100\%, in Latin America $92.31 \%$, in Southeast Asia $20 \%$ and in West Africa $28.57 \%$ of the female interviewees have a bank account (Table A2.5, Annex 2). Especially in East Africa, West Africa and India there is a large variety of banks in use where respondents have an account. For East Africa $34.29 \%$ of the respondents mentioned that they are able to transfer money with a cell phone or computer. In West Africa $25.76 \%$ of the respondents use a cell phone or computer to transfer money, in India $5.56 \%$ and in Southeast Asia 6.67\%. None of the Latin American respondents mentioned being able to transfer money with a cell phone or computer. 


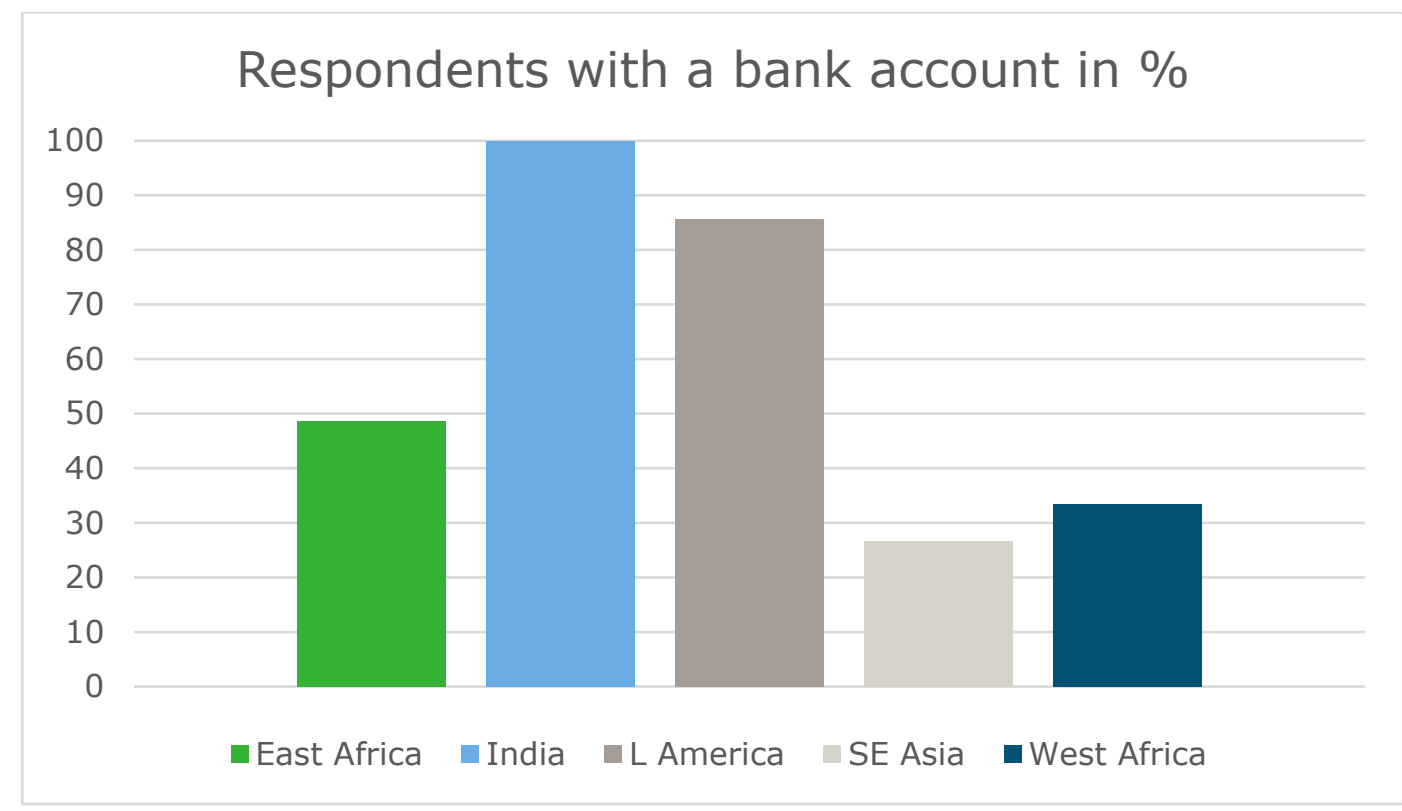

Figure 5: Percentage of respondents with a bank account

Financial transaction with a computer or cell phone

In India, Latin America and Southeast Asia, more than $90 \%$ of the respondents pointed out that they can make financial transactions with a computer or cell phone. In Africa this figure is much lower namely $30 \%$ for Easy Africa $30 \%$ and $56 \%$ for West Africa $56 \%$ (Figure 6)

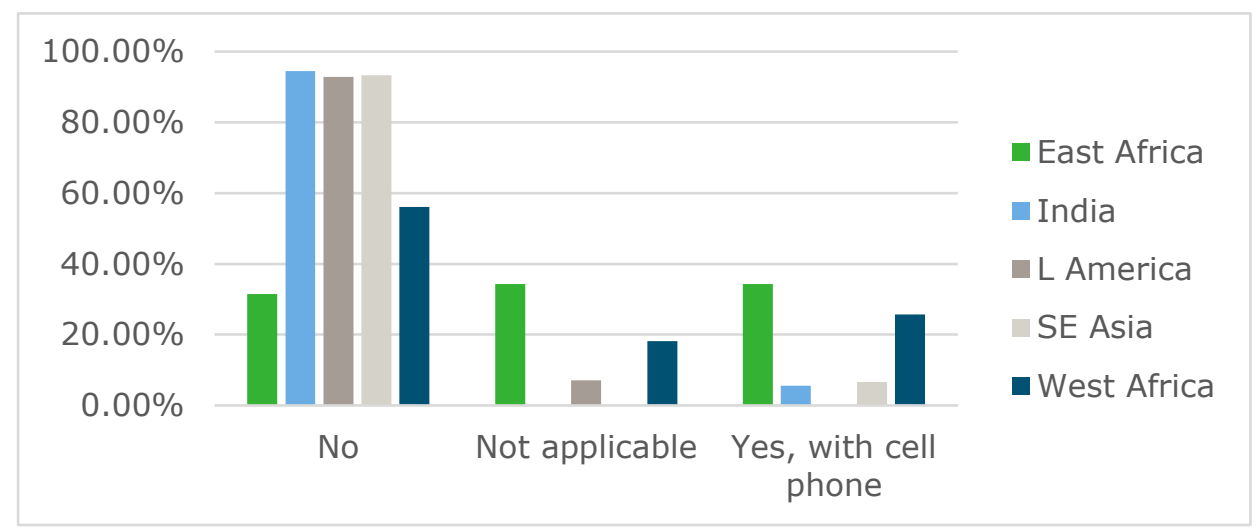

Figure 6: Percentage of respondents making use of cell phone or computer to make financial transactions

The ability to get a loan, to save money and to keep money in a safe location were amongst the three most important benefits of having a bank account (Table A2.6, Annex 2).

\section{Other formal financial institutions}

For the five CCAFS regions, table 5 shows that respondents make use of cooperatives and micro finance institutions, and to a lesser extent SACCOs, post offices and others (not provided as option in the questionnaire) to receive financial products and services. $24 \%$ of the East African interviewees use microfinance institutions (mainly women) and $21 \%$ receive financial services and products from SACCOs (mainly men) (Table A2.7, Annex 2). In India and West Africa cooperatives are frequently in use for receiving financial products and services. Both in India and West Africa cooperatives are predominantly used by men. In West Africa, the majority of the respondents make use of microfinance institutions. Most of them are men. In Southeast Asia $40 \%$ use microfinance institutions and $25 \%$ of SACCOs. For a relatively high percentage of respondents, this question was not applicable. Maybe they do not make use of the formal financial institutions (in addition to banks). We remark that although we suspect the surveyed people have better access to credit as they are part of a climate smart village, this amount can still be considered to be low for climate smart agriculture. 
Table 5: Formal financial institutions (others than bank) proving financial services and products

\begin{tabular}{|c|c|c|c|c|c|c|c|}
\hline Financial institutions & L America & $\begin{array}{l}\text { West } \\
\text { Africa }\end{array}$ & & $\begin{array}{l}\text { East } \\
\text { Africa }\end{array}$ & SE Asia & India & Grand Total \\
\hline Cooperative & $19 \%$ & & $23 \%$ & $5 \%$ & $0 \%$ & $58 \%$ & $22 \%$ \\
\hline Microfinance institution & $25 \%$ & & $25 \%$ & $24 \%$ & $40 \%$ & $4 \%$ & $23 \%$ \\
\hline Post office & $19 \%$ & & $2 \%$ & $5 \%$ & $0 \%$ & $23 \%$ & $7 \%$ \\
\hline SACCO & $0 \%$ & & $6 \%$ & $21 \%$ & $25 \%$ & $0 \%$ & $10 \%$ \\
\hline Other & $0 \%$ & & $7 \%$ & $3 \%$ & $20 \%$ & $4 \%$ & $7 \%$ \\
\hline Not applicable & $38 \%$ & & $36 \%$ & $42 \%$ & $15 \%$ & $12 \%$ & $31 \%$ \\
\hline Grand Total & $100 \%$ & & $100 \%$ & $100 \%$ & $100 \%$ & $100 \%$ & $100 \%$ \\
\hline
\end{tabular}

Informal financial institutions

Table 6 shows that for all regions together the most frequently used informal institutions include the merrygo-round schemes (or any other informal saving network) (28\%), shop keepers (14.5\%) and traders (14.51\%).

Looking at specific regions, we observe that the merry-go-round scheme (or any other informal saving network) is frequently used for receiving financial products and services in Southeast Asia (by $71.43 \%$ of the respondents), in Latin American (42.86\%), in East Africa (by 31.88\%) and West Africa (by 24.69\%). Especially in West Africa and Latin America, mainly women access a merry go round scheme for finance (Table A2.8, Annex 2). In India, traders appear to be an important financial institution for receiving financial products and services, especially for women. 
Table 6: Informal /local financial institutions which financial services and products are used

\begin{tabular}{|c|c|c|c|c|c|c|}
\hline Financial institution & $\begin{array}{l}\text { East } \\
\text { Africa }\end{array}$ & India & L America & SE Asia & $\begin{array}{l}\text { West } \\
\text { Africa }\end{array}$ & Grand Total \\
\hline \multicolumn{7}{|l|}{ Value Chain } \\
\hline $\begin{array}{l}\text { Input supplier (e.g. goods } \\
\text { on credit) }\end{array}$ & $4 \%$ & $31 \%$ & $7 \%$ & $0 \%$ & $5 \%$ & $8 \%$ \\
\hline Processing industry & $0 \%$ & $0 \%$ & $0 \%$ & $0 \%$ & $4 \%$ & $2 \%$ \\
\hline Trader & $20 \%$ & $47 \%$ & $0 \%$ & $0 \%$ & $4 \%$ & $14 \%$ \\
\hline \multicolumn{7}{|l|}{ Community Finance } \\
\hline Merry-go-round & $32 \%$ & $0 \%$ & $43 \%$ & $71 \%$ & $23 \%$ & $28 \%$ \\
\hline A money guard & $0 \%$ & $0 \%$ & $0 \%$ & $19 \%$ & $7 \%$ & $5 \%$ \\
\hline $\begin{array}{l}\text { Savings collectors (not } \\
\text { closely related to the family) }\end{array}$ & $4 \%$ & $0 \%$ & $0 \%$ & $10 \%$ & $6 \%$ & $5 \%$ \\
\hline Other groups & $3 \%$ & $3 \%$ & $0 \%$ & $0 \%$ & $5 \%$ & $3 \%$ \\
\hline Remittances funds & $10 \%$ & $0 \%$ & $0 \%$ & $0 \%$ & $7 \%$ & $6 \%$ \\
\hline Shop keepers & $19 \%$ & $16 \%$ & $21 \%$ & $0 \%$ & $13 \%$ & $15 \%$ \\
\hline Vouchers & $6 \%$ & $0 \%$ & $0 \%$ & $0 \%$ & $0 \%$ & $2 \%$ \\
\hline Other & $0 \%$ & $3 \%$ & $14 \%$ & $0 \%$ & $1 \%$ & $2 \%$ \\
\hline not applicable & $1 \%$ & $0 \%$ & $14 \%$ & $0 \%$ & $23 \%$ & $11 \%$ \\
\hline Grand Total & $100 \%$ & $100 \%$ & $100 \%$ & $100 \%$ & $100 \%$ & $100 \%$ \\
\hline
\end{tabular}

\section{Motivations for borrowing money from (in)formal institutions}

For the five CCAFS regions, the three most frequently cited reasons for borrowing money from banks or other formal and informal financial institutions include paying school fees (19.18\% of the respondents), paying for other household/family expenditures (18.84\%) and paying food (17.47\%) (table 7 ). Looking at reasons most frequently mentioned by respondents from specific regions, we observe the following. For the East African respondents 'paying for food' and 'schools fees' seem to be reasons of equal importance. $31.58 \%$ of the Indian respondents mentioned that they borrow money for paying other household/family expenditures (e.g. marriage). $46.67 \%$ Of the Latin American use loans to invest in farm/ company equipment. For Southeast Asia investments in (aquaculture) farm inputs and for West Africa paying food are most frequently cited reasons.

Table 7: Reasons for borrowing money

\begin{tabular}{|c|c|c|c|c|c|c|}
\hline Reasons & $\begin{array}{l}\mathrm{L} \\
\text { America }\end{array}$ & $\begin{array}{l}\text { West } \\
\text { Africa }\end{array}$ & $\begin{array}{l}\text { East } \\
\text { Africa }\end{array}$ & $\begin{array}{l}\text { SE } \\
\text { Asia }\end{array}$ & India & Grand Total \\
\hline \multicolumn{7}{|l|}{ Production expenditures } \\
\hline $\begin{array}{l}\text { To build a factory, sheds etc. to grow my } \\
\text { farm/company }\end{array}$ & $0 \%$ & $2 \%$ & $0 \%$ & $0 \%$ & $0 \%$ & $1 \%$ \\
\hline $\begin{array}{l}\text { To finance negative events related to } \\
\text { climate change }\end{array}$ & $0 \%$ & $1 \%$ & $1 \%$ & $7 \%$ & $11 \%$ & $3 \%$ \\
\hline To hire (new) personnel & $0 \%$ & $4 \%$ & $0 \%$ & $4 \%$ & $0 \%$ & $2 \%$ \\
\hline $\begin{array}{l}\text { To invest in (aquaculture) farm inputs } \\
\text { (for example fingerlings and feed) }\end{array}$ & $13 \%$ & $19 \%$ & $0 \%$ & $50 \%$ & $11 \%$ & $16 \%$ \\
\hline $\begin{array}{l}\text { To invest in equipment of my } \\
\text { farm/company }\end{array}$ & $47 \%$ & $7 \%$ & $1 \%$ & $14 \%$ & $11 \%$ & $9 \%$ \\
\hline To renew equipment & $0 \%$ & $1 \%$ & $1 \%$ & $0 \%$ & $5 \%$ & $2 \%$ \\
\hline $\begin{array}{l}\text { To finance negative events not related } \\
\text { to climate change } \\
\text { Household expenditures }\end{array}$ & $0 \%$ & $3 \%$ & $4 \%$ & $0 \%$ & $5 \%$ & $3 \%$ \\
\hline$\overline{T o}$ pay for food & $0 \%$ & $19 \%$ & $32 \%$ & $4 \%$ & $0 \%$ & $17 \%$ \\
\hline $\begin{array}{l}\text { To pay for other household/family } \\
\text { expenditures }\end{array}$ & $20 \%$ & $15 \%$ & $25 \%$ & $4 \%$ & $32 \%$ & $19 \%$ \\
\hline To pay for school fees & $0 \%$ & $16 \%$ & $32 \%$ & $7 \%$ & $24 \%$ & $19 \%$ \\
\hline Other & $20 \%$ & $12 \%$ & $3 \%$ & $11 \%$ & $3 \%$ & $9 \%$ \\
\hline Grand Total & $100 \%$ & $100 \%$ & $100 \%$ & $100 \%$ & $100 \%$ & $100 \%$ \\
\hline
\end{tabular}


Table 8 presents strategies of respondents to finance farm investments such as inputs (seeds, fertilizers, labour) and equipment. Respondents could mention maximum three options. In descending order of frequency of mention, 'self-supporting and not using external finance', 'selling livestock, crop or aquaculture products', 'borrowing money from family/friends' and 'borrowing money from a bank' are the four frequently used strategies.

Table 8: Strategies for financing farm investments

\begin{tabular}{|c|c|c|c|c|c|c|}
\hline Strategies & $\begin{array}{l}\text { L } \\
\text { America }\end{array}$ & West Africa & East Africa & SE Asia & India & Grand Total \\
\hline $\begin{array}{l}\text { By borrowing money } \\
\text { from a bank }\end{array}$ & $5 \%$ & $19 \%$ & $7 \%$ & $32 \%$ & $18 \%$ & $16 \%$ \\
\hline By having an insurance & $0 \%$ & $3 \%$ & $0 \%$ & $0 \%$ & $0 \%$ & $1 \%$ \\
\hline $\begin{array}{l}\text { By selling livestock, crop } \\
\text { or aquaculture products }\end{array}$ & $65 \%$ & $18 \%$ & $22 \%$ & $14 \%$ & $0 \%$ & $20 \%$ \\
\hline $\begin{array}{l}\text { By subsidy or gifts (and } \\
\text { by whom?) }\end{array}$ & $0 \%$ & $6 \%$ & $13 \%$ & $0 \%$ & $11 \%$ & $7 \%$ \\
\hline $\begin{array}{l}\text { By taking a temporary } \\
\text { job }\end{array}$ & $5 \%$ & $6 \%$ & $3 \%$ & $0 \%$ & $0 \%$ & $4 \%$ \\
\hline $\begin{array}{l}\text { I am self-supporting and } \\
\text { do not use external } \\
\text { finance }\end{array}$ & $25 \%$ & $24 \%$ & $25 \%$ & $25 \%$ & $18 \%$ & $24 \%$ \\
\hline $\begin{array}{l}\text { By borrowing money } \\
\text { from family/friends }\end{array}$ & $0 \%$ & $15 \%$ & $22 \%$ & $29 \%$ & $11 \%$ & $16 \%$ \\
\hline Other & $0 \%$ & $10 \%$ & $8 \%$ & $0 \%$ & $43 \%$ & $11 \%$ \\
\hline Grand Total & $100 \%$ & $100 \%$ & $100 \%$ & $100 \%$ & $100 \%$ & $100 \%$ \\
\hline
\end{tabular}

Considering specific regions, $25.00 \%$ of the East African respondents use their own savings to finance farm investments, $21.67 \%$ sell their livestock, crop or aquaculture products and $21.67 \%$ borrow money from family/friends. $42.86 \%$ Of the Indian respondents indicated that they use other sources than provided in the questionnaire, which may include government subsidy. In Southeast Asian, diverse strategies are in use of which borrowing money from a bank appears to be the most frequently cited (by $32.14 \%$ ). For Latin America $65.00 \%$ of the respondents sell livestock, crop or aquaculture products to finance farm investments. $24.07 \%$ Of the West African interviewees are 'self-supporting'.

\subsubsection{Credit sources and allocation}

For the five CCAFS regions, $64.19 \%$ of the respondents received credit last year $(62.86 \%$ East African respondents, 77.78\% India, 64.29\% Latin America, 93.33\% Southeast Asian and 54.55\% West African). Amongst those respondents who received a loan, $51.58 \%$ were women (Table A2.9, Annex 2).

\section{Amount of loan}

The amount of obtained credit varies considerably between the CCAFS regions (Table 9). For example, a loan of 1000 - 3000 USD was taken last year by $50 \%$ of the Latin American respondents. A loan of the same amount was taken by $26.67 \%$ of the Southeast Asian respondents and by only $2.94 \%$ of the East African respondents. None of the West African respondents took a loan of this amount. Southeast Asian respondents, however mainly by males, took by Indian and to a lesser extent relatively large loans (> 10,000 euros). The East and West Africa respondents who received small amount of credits, were predominantly women. 
Table 9: Amount of received credit/loan last year (2016)

\begin{tabular}{|c|c|c|c|c|c|c|}
\hline Credit/ loan in USD & $\begin{array}{l}\text { L } \\
\text { America }\end{array}$ & $\begin{array}{l}\text { West } \\
\text { Africa }\end{array}$ & East Africa & $\begin{array}{l}\text { SE } \\
\text { Asia }\end{array}$ & India & $\begin{array}{l}\text { Grand } \\
\text { Total }\end{array}$ \\
\hline$<100$ & $0 \%$ & $36 \%$ & $24 \%$ & $0 \%$ & $0 \%$ & $22 \%$ \\
\hline $100-1000$ & $7 \%$ & $18 \%$ & $38 \%$ & $13 \%$ & $0 \%$ & $19 \%$ \\
\hline $1000-3000$ & $50 \%$ & $0 \%$ & $3 \%$ & $27 \%$ & $17 \%$ & $10 \%$ \\
\hline $3000-6000$ & $7 \%$ & $0 \%$ & $0 \%$ & $40 \%$ & $11 \%$ & $6 \%$ \\
\hline $6000-10000$ & $0 \%$ & $0 \%$ & $0 \%$ & $0 \%$ & $28 \%$ & $3 \%$ \\
\hline$>10000$ & $0 \%$ & $0 \%$ & $0 \%$ & $7 \%$ & $17 \%$ & $3 \%$ \\
\hline Not applicable & $36 \%$ & $45 \%$ & $35 \%$ & $13 \%$ & $28 \%$ & $37 \%$ \\
\hline (blank) & $0 \%$ & $0 \%$ & $0 \%$ & $0 \%$ & $0 \%$ & $0 \%$ \\
\hline Grand Total & $100 \%$ & $100 \%$ & $100 \%$ & $100 \%$ & $100 \%$ & $100 \%$ \\
\hline
\end{tabular}

Financial institutions that provided credit/loans last year

Overall, for the CCAFS regions, $19 \%$ of the respondents took last year's loan from the VSLA and $15.88 \%$ from a bank. In East and West Africa, VSLA were most frequently cited as the financial institution from which respondents, especially women, received the loan. In India, most of the female respondents received a loan from traders. In Southeast Asia, male and female respondents predominantly used a bank to take a loan. In Latin America, only female respondents obtained a credit from a bank. Male respondents tend to go to family for loans (Table A2.10, Annex 2).

Table 10: Financial institutions that provided a loan/credit last year

\begin{tabular}{|c|c|c|c|c|c|c|}
\hline $\begin{array}{l}\text { Financial } \\
\text { institutions }\end{array}$ & L America & West Africa & $\begin{array}{c}\text { East } \\
\text { Africa }\end{array}$ & SE Asia & India & Grand Total \\
\hline Bank & $43 \%$ & $3 \%$ & $5 \%$ & $42 \%$ & $33 \%$ & $16 \%$ \\
\hline Cooperative & $7 \%$ & $1 \%$ & $3 \%$ & $0 \%$ & $0 \%$ & $2 \%$ \\
\hline Family & $7 \%$ & $4 \%$ & $0 \%$ & $5 \%$ & $4 \%$ & $4 \%$ \\
\hline Friend & $7 \%$ & $6 \%$ & $3 \%$ & $5 \%$ & $4 \%$ & $5 \%$ \\
\hline $\mathrm{MFI}$ & $0 \%$ & $10 \%$ & $8 \%$ & $0 \%$ & $0 \%$ & $6 \%$ \\
\hline Moneylender & $0 \%$ & $3 \%$ & $0 \%$ & $0 \%$ & $4 \%$ & $2 \%$ \\
\hline Others & $0 \%$ & $7 \%$ & $8 \%$ & $16 \%$ & $0 \%$ & $6 \%$ \\
\hline SACCO & $0 \%$ & $0 \%$ & $13 \%$ & $11 \%$ & $0 \%$ & $4 \%$ \\
\hline Trader & $0 \%$ & $0 \%$ & $0 \%$ & $0 \%$ & $41 \%$ & $6 \%$ \\
\hline VSLA & 0 & $31 \%$ & $21 \%$ & $11 \%$ & $0 \%$ & $19 \%$ \\
\hline $\begin{array}{l}\text { Not } \\
\text { applicable }\end{array}$ & $36 \%$ & $36 \%$ & $39 \%$ & $11 \%$ & $15 \%$ & $31 \%$ \\
\hline Grand Total & $100 \%$ & $100 \%$ & $100 \%$ & $100 \%$ & $100 \%$ & $100 \%$ \\
\hline
\end{tabular}

\section{Interest rates}

Interest rates on loans varied from $<1 \%$ and $>40 \%$ per year. Looking at the interest rate paid by most of the respondents per regions we can observe the following: In East Africa, $48.57 \%$ of all respondents paid an interest rate of $5-10 \%$, in India, $44.44 \%$ paid an interest rate of $20-30 \%$, in Latin America $50 \%$ paid an interests rate of $1-5 \%$, In Southeast Asia $85.71 \%$ of the interviewees paid an interest rate of $<1 \%$ (Table 11). The data do not provide insight into the difference of interest rates between men and women. 
Table 11: Interest rate on loans

\begin{tabular}{lcccccc} 
Interest rate & East Africa & India & L America & SE Asia & West Africa & Grand Total \\
\hline$<1 \%$ & $0.00 \%$ & $0.00 \%$ & $14.29 \%$ & $85.71 \%$ & $3.03 \%$ & $10.88 \%$ \\
$1-5 \%$ & $8.57 \%$ & $16.67 \%$ & $50.00 \%$ & $0.00 \%$ & $7.58 \%$ & $12.24 \%$ \\
$5-10 \%$ & $48.57 \%$ & $5.56 \%$ & $0.00 \%$ & $14.29 \%$ & $13.64 \%$ & $19.73 \%$ \\
$10-20 \%$ & $5.71 \%$ & $16.67 \%$ & $0.00 \%$ & $0.00 \%$ & $15.15 \%$ & $10.20 \%$ \\
$20-30 \%$ & $0.00 \%$ & $44.44 \%$ & $0.00 \%$ & $0.00 \%$ & $4.55 \%$ & $7.48 \%$ \\
$30-40 \%$ & $0.00 \%$ & $0.00 \%$ & $0.00 \%$ & $0.00 \%$ & $7.58 \%$ & $3.40 \%$ \\
$>40 \%$ & $0.00 \%$ & $0.00 \%$ & $0.00 \%$ & $0.00 \%$ & $1.52 \%$ & $0.68 \%$ \\
Not applicable & $37.14 \%$ & $16.67 \%$ & $35.71 \%$ & $0.00 \%$ & $46.97 \%$ & $35.37 \%$ \\
\hline Grand Total & $\mathbf{1 0 0 . 0 0 \%}$ & $\mathbf{1 0 0 . 0 0 \%}$ & $\mathbf{1 0 0 . 0 0 \%}$ & $\mathbf{1 0 0 . 0 0 \%}$ & $\mathbf{1 0 0 . 0 0 \%}$ & $\mathbf{1 0 0 . 0 0 \%}$
\end{tabular}

We have surveyed the interest rate on loans. It is important to acknowledge these rates can vary significantly depending on the size of the loan, the duration of the loand, subsidies on interest, the type of lender and other variables. Nominal rates can have hidden costs and calculation methods, furthermore we suspect some people may have cited the monthly interest rate as it is more often communicated than the annual rate. Therefore we should be careful in drawing conclusions from this table.

\section{Reimbursement periods - Repayment modalities}

Table 12 shows that in Latin America and Southeast Asia a relatively large part of the respondents take loans for farm investments with a relatively long reimbursement period of 24-36 months or > 36 months, which may (partly) explain the relatively low interest rates in these two regions. In order to draw better conclusions about the link of the interest rate and the reimbursement period, further study would be required, which is out of the scope of this study.

Table 12: Reimbursement periods

\begin{tabular}{lrrrrrc} 
Months & East Africa & India & L America & SE Asia & West Africa & Grand Total \\
\hline$<3$ & $34.29 \%$ & $0.00 \%$ & $7.14 \%$ & $6.67 \%$ & $28.79 \%$ & $22.30 \%$ \\
$3-6$ & $11.43 \%$ & $61.11 \%$ & $0.00 \%$ & $6.67 \%$ & $10.61 \%$ & $15.54 \%$ \\
$6-12$ & $11.43 \%$ & $0.00 \%$ & $0.00 \%$ & $13.33 \%$ & $10.61 \%$ & $8.78 \%$ \\
$12-24$ & $0.00 \%$ & $0.00 \%$ & $7.14 \%$ & $20.00 \%$ & $0.00 \%$ & $2.70 \%$ \\
$24-36$ & $0.00 \%$ & $0.00 \%$ & $21.43 \%$ & $46.67 \%$ & $1.52 \%$ & $7.43 \%$ \\
$>36$ & $0.00 \%$ & $5.56 \%$ & $28.57 \%$ & $0.00 \%$ & $0.00 \%$ & $3.38 \%$ \\
No duration for credit card & $0.00 \%$ & $11.11 \%$ & $0.00 \%$ & $0.00 \%$ & $0.00 \%$ & $1.35 \%$ \\
Not applicable & $42.86 \%$ & $22.22 \%$ & $35.71 \%$ & $6.67 \%$ & $48.48 \%$ & $38.51 \%$ \\
\hline Grand Total & $\mathbf{1 0 0 . 0 0 \%}$ & $\mathbf{1 0 0 . 0 0 \%}$ & $\mathbf{1 0 0 . 0 0 \%}$ & $\mathbf{1 0 0 . 0 0 \%}$ & $\mathbf{1 0 0 . 0 0 \%}$ & $\mathbf{1 0 0 . 0 0 \%}$
\end{tabular}

Repayment modality also differs between the regions. In East and West Africa, most of the respondents pay back every month, whereas in India interviewees mentioned they pay back after harvest and in Latin America at the end of the year (Table A2.11, Annex 2).

\section{Collateral}

For $38.51 \%$ of all respondents the question whether they were asked for a collateral or not was not applicable. 29.05\% Indicated that they were asked for a collateral and 32.43\% not. In East Africa 48.57 $\%$ were demanded a collateral ( $64.71 \%$ of whom were women), in India $44.44 \%$ (all of them were male), in Southeast Asia 60.00\% (22.22\% of whom were women), in West Africa $13.64 \%$ (33.33\% of whom were women). In Latin America, there was no request for a collateral (table 13). In India and SE Asia, often farm/land is used as collateral, whereas in East Africa animals are used, in Southeast Asian a house certificate and in Latin America respondents mentioned they are often requested to deposit money. 


\begin{tabular}{|c|c|c|c|c|c|c|}
\hline Request for collateral & East Africa & India & $\begin{array}{l}\text { L } \\
\text { America }\end{array}$ & SE Asia & $\begin{array}{l}\text { West } \\
\text { Africa }\end{array}$ & $\begin{array}{l}\text { Grand } \\
\text { Total }\end{array}$ \\
\hline No & $11.43 \%$ & $27.78 \%$ & $64.29 \%$ & $33.33 \%$ & $37.88 \%$ & $32.43 \%$ \\
\hline female & $50.00 \%$ & $60.00 \%$ & $88.89 \%$ & $60.00 \%$ & $60.00 \%$ & $64.58 \%$ \\
\hline male & $50.00 \%$ & $40.00 \%$ & $11.11 \%$ & $40.00 \%$ & $40.00 \%$ & $35.42 \%$ \\
\hline Not applicable & $40.00 \%$ & $27.78 \%$ & $35.71 \%$ & $6.67 \%$ & $48.48 \%$ & $38.51 \%$ \\
\hline female & $42.86 \%$ & $20.00 \%$ & $80.00 \%$ & $0.00 \%$ & $31.25 \%$ & $36.84 \%$ \\
\hline male & $57.14 \%$ & $80.00 \%$ & $20.00 \%$ & $100.00 \%$ & $68.75 \%$ & $63.16 \%$ \\
\hline Yes & $48.57 \%$ & $44.44 \%$ & $0.00 \%$ & $60.00 \%$ & $13.64 \%$ & $29.05 \%$ \\
\hline female & $64.71 \%$ & $0.00 \%$ & & $22.22 \%$ & $33.33 \%$ & $37.21 \%$ \\
\hline male & $35.29 \%$ & $100.00 \%$ & & $77.78 \%$ & $66.67 \%$ & $62.79 \%$ \\
\hline Grand Total & $100.00 \%$ & $100.00 \%$ & $100.00 \%$ & $100.00 \%$ & $100.00 \%$ & $100.00 \%$ \\
\hline
\end{tabular}

Table 13: Requirement of collateral, differentiated by gender

\section{Allocation of credit received}

For the most important loan, respondents were also asked about the purpose for which they used the received credit. In East Africa, the credit was mainly used investments in crop and land management, and to a lesser extent for schooling and livestock management. In India, priority was given to invest in crop management and to a lesser extent to land management and household expenses. In Latin America respondents used the loan for household expenses, crop and land management mainly. In West Africa, the most important loan was allocated to crop management. In Southeast Asia, the loan was predominantly used for investments in aquaculture (Figure 7)

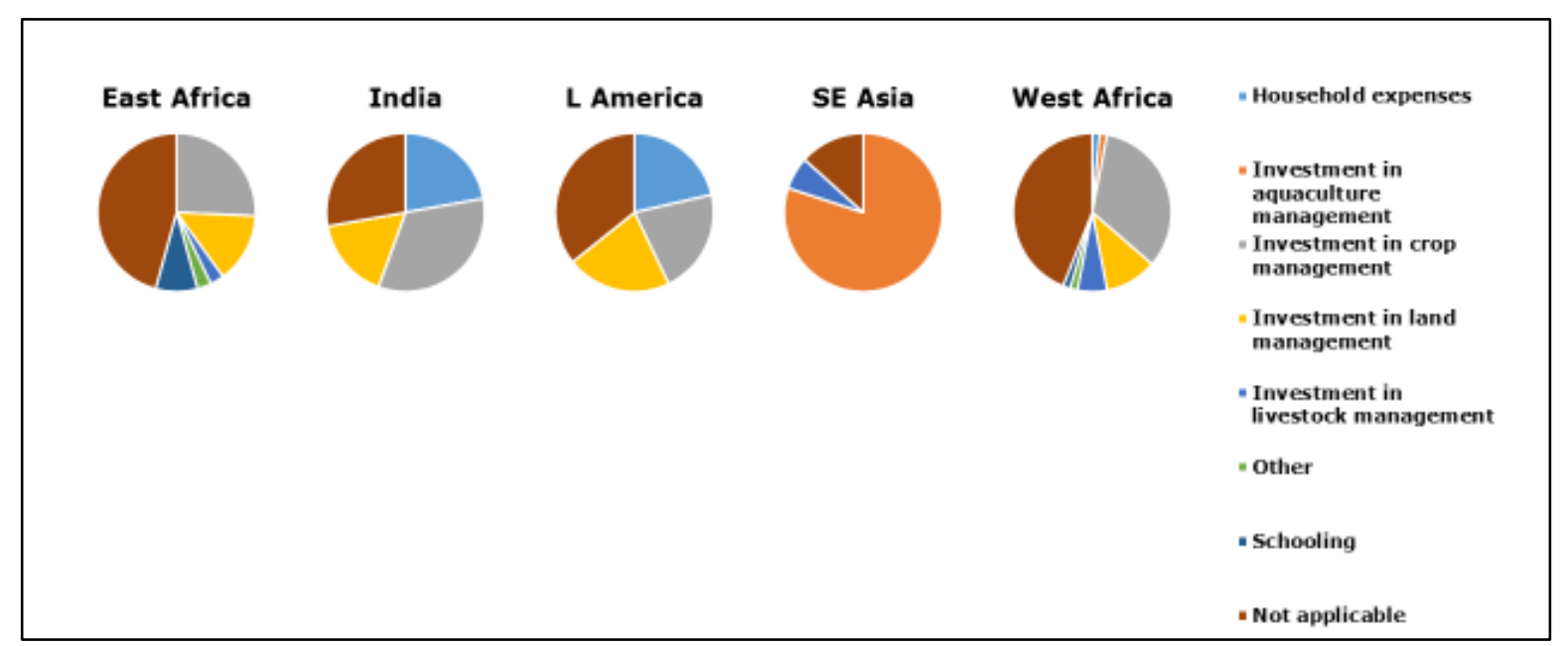

Figure 7: Allocation of credit received

Reasons for not asking for credit

For most of the respondents in all five regions the question about reasons for not asking credit from a bank was not applicable. Relatively few respondents from West Africa and Latin America mentioned that banks have no confidence in farmers as farming is very risky, interest rates are too high and, to a lesser extent, they do know the procedures (Table A2.12, Annex 2). 


\subsection{Climate smart agriculture and investments}

This section presents the results on the investments in different Climate Smart Agriculture practices and technologies including:

1. Soil conservation and land preparation;

2. Water use efficiency or water conservation technologies and practices;

3. Weather forecasting services and/or index based insurances;

4. Nutrient management technologies and practices;

5. Other Climate Smart Agriculture practices and technologies.

For each domain, the same set of questions are applied. Respondents in the Southeast Asian region are only involved in fish farming/ aqua culture. Therefore, they did not reply to questions related to themes 1 4.

\subsubsection{Soil conservation and land preparation}

Results are presented in Figure 8 and the tables A3.1-3.5 in Annex 3.

In East Africa men and women apply most often water management (by $42.86 \%$ of the respondents) and nutrient management (by $26.79 \%)^{1}$ (Table A3.1). $62.86 \%$ Of the East Africa respondents invested between $0-50$ in soil conservation or land preparation technologies and less than $10 \%$ between $100-500 \$$ last year. Women invested relatively more than men (Table A3.2). The most important institutions to finance these investments include the merry-go-round scheme $(27.50 \%$ of the respondents) and remittances funds (17.50\% of the respondents). Women appear to use more often remittance funds for farm investment than men do (Table A3.3 table). 15\% Of the East African interviewees use their own savings to finance these activities. Training (28.26\%) and lower interest rates $(26.09 \%)$ were most frequently mentioned changes to facilitate soil conservation or land preparation technologies or practices. Especially men suggested a lower interest rate (Table A.3.5).

In India the Land Laser Leveller to level (irrigated) rice fields is used by $32.14 \%$ of the respondents and $26.79 \%$ use the Turbo Happy Seeder allowing weed to be seeded just after paddy harvesting without the need of rice stubble burning (Table A3.1). Last year $27.78 \%$ of the respondents, predominantly women, invested between $100-500 \$$ in soil conservation-land preparation technologies, $27.78 \%$ invested more than 1000 (Table A3.2). 44.44\% Used their own savings to finance these investments and $11.11 \%$ received a loan from the bank. Women received a loan from traders to finance these climate smart activities (Table A3.3). 85.00\% Of the respondents indicated not to perceive any risks related to these investments (Table A3.4). 35.00\% Of the respondents did not see any need for changes in the financial services delivered, $20 \%$ recommended more subsidy to support soil conservation or land preparation technologies or practices (Table A3.5).

For Latin America $28.57 \%$ of the respondents apply nutrient management as soil management practice, $26 \%$ use ploughing and $26.53 \%$ practice zero/minimum tillage (Table A3.1). Last year respondents $42.86 \%$ invested between $100-500 \$$ in soil conservation or land preparation technologies and practices and $28.57 \%$ (relatively more men) invested between 500-1000\$ (Table A3.2). 70.59\% financed these technologies and practices through the sale of farm products (Table A3.3). $42.86 \%$ mentioned diseases as major risk (Table 3.4 ) and $62.50 \%$ of the respondents would like to have more subsides and $18.75 \%$ lower interest rates to facilitate soil conservation or land preparation technologies or practices (Table A3.5).

For Southeast Asia none of the respondents apply soil conservation and/or land preparation technologies or practices. Questions concerning financing these technologies /practices and related risks were relevant.

\footnotetext{
${ }^{1}$ Respondents were allowed to mention more than one practice or technology.
} 
For West Africa $28.70 \%$ of the respondents practice water management and $28.70 \%$ RNA (Régénération Naturelle Assistée) (Table A3.1). Last year 38.46\% of the respondents did not invest in soil conservation and land preparation and $36.92 \% 0-50 \$$ only (Table A3.2). The figures do not show significant differences in investment practices between men and women. A range of different sources are used to finance soil conservation and land management technologies, of which the use of own saving was most frequently noted (Table A3.3). 38.36\% Mentioned not to perceive particular risks, $16.44 \%$ perceive the high costs involved as risk (Table A3.4). 11.11\% Of the interviewees suggested to increase opportunities to get easy access to financial services (Table A3.5).

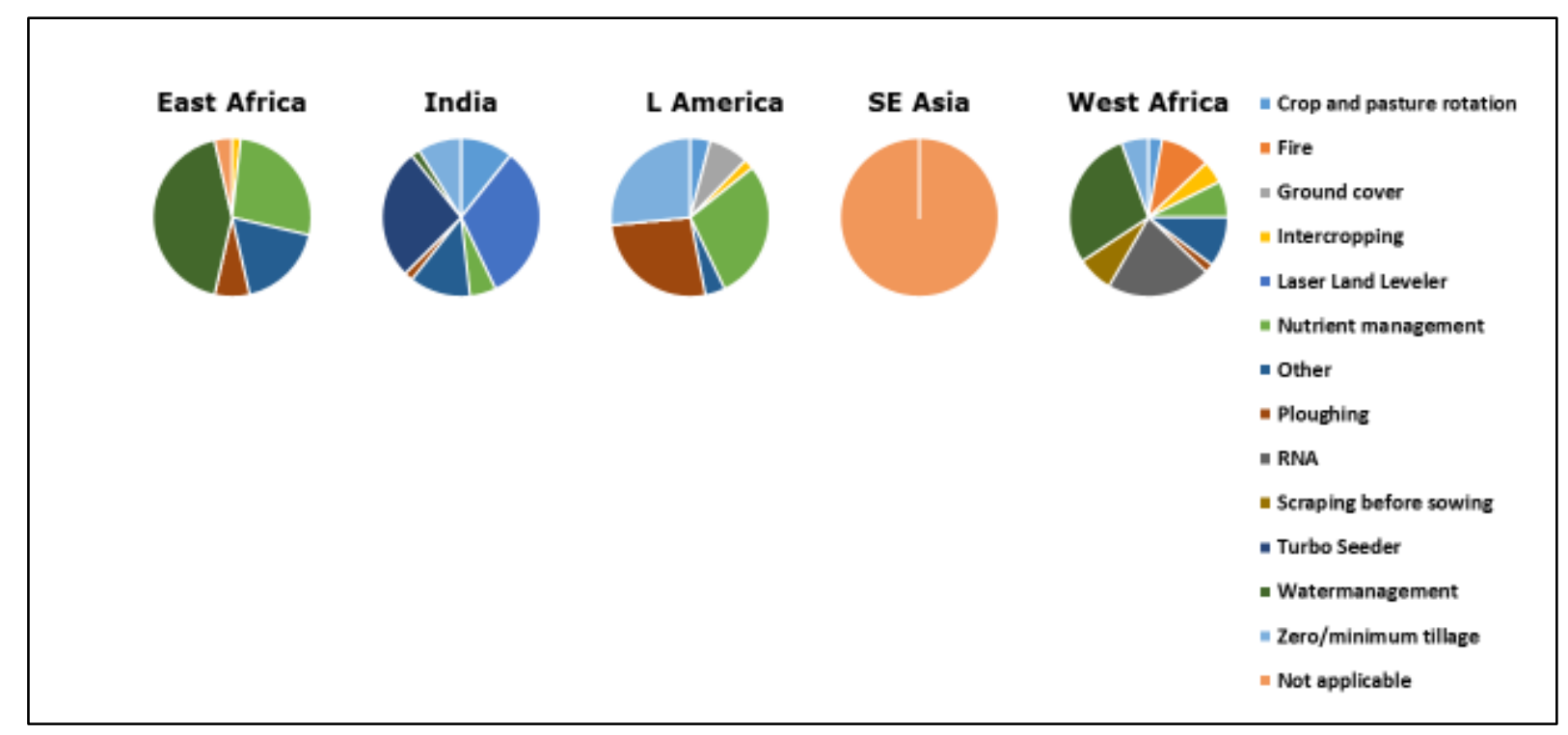

Figure 8: Types of soil conservation or land preparation technologies or practices applied

\subsubsection{Water use efficiency or water conservation technologies and practices}

Results are presented in figure 9 and in tables A3.6 - A3.10 in Annex 3.

For East Africa $35.14 \%$ of the respondents apply water conservation technologies and practices and $29.73 \%$ irrigation (Table A3.6). 45.71\% Of the interviewees invested between 0-50\$ in these technologies and $11.43 \%$ (only men) between 100-500\$ last year (Table A3.7). The financial sources used for these investments include a merry-go-round scheme (or any other informal saving network) (by $25.00 \%$ of the respondents), remittances funds (by $17.50 \%$ ) and 'own savings' (by 12.50\%) (Table A3.8). Pest and diseases were most frequently mentioned as risks, namely by $21.62 \%$. Risk of droughts was brought up by $16.22 \%$ of the interviewees (Table A3.9). The three most frequently cited changes to support water use efficiency or water conservation technologies and practices include training (by $21.05 \%$ of the respondents), more subsidy for adaptation $(15.79 \%)$ and more soft loans (by $15.70 \%)$ (Table A3.10).

For India $28.57 \%$ of the respondents apply bed planting, $26.19 \%$ use the laser land leveller and $11.90 \%$ Direct Seeded Rice (DSR) (Table A3.6). 33.33\% Invested between 0-50\$ in these technologies, $11.11 \%$ between $50-100 \$$, but $22.22 \%$ did not invest in any of these last year. Men made relatively larger investment than women (Table A3.7). 38.89\% Of respondents indicated that they were self-financing these investments, $11.11 \%$ received credit from a bank and $11.1 \%$, especially women, from traders (Table A3.8). $61.11 \%$ of the interviewees mentioned not to perceive any risk in relation to these technologies and practices (Table A3.9). The majority of the respondents for whom this question was applicable did not suggest any change in the offered financial services, but $11.11 \%$ recommended a lower interest rate to support water use efficiency or water conservation technologies and practices (Table A3.10). 
For Latin America $52.94 \%$ of the respondents apply water conservation practices, 38.24\% mentioned to use drip irrigation as water efficiency technology. Men appear to prefer water conservation practices, whereas women drip irrigation (Table A3.6). 35.71\% Of the respondents did not invest water use efficiency or water conservation technologies and practices, $35.71 \%$ invested between $0-50 \$$ and $21.43 \%$ between $100-500 \$$ last year. Noteworthy is that $41.67 \%$ of the women did not invest at all (Table A3.7). The CCAFS - Ecohabitats project appears to be an important source of finance for $57.89 \%$ of the respondents. $31.58 \%$ Used the sale of farm products as source to finance these investments (Table A3.8). 40\% mentioned drought as risk for these climate smart technologies and practices, but 33.33\% mentioned not to perceive any risk (Table A3.9). Out of the most preferred changes, $29.41 \%$ of the respondents recommended more subsidy opportunities and $23.53 \%$ suggested a lower interest rate (Table A3.10).

For Southeast Asia, none of the respondents applied water use efficiency or water conservation technologies and practices. Questions concerning financing these technologies /practices and related risks were not relevant.

In West Africa technologies and practices most frequently applied are RNA (by $25.30 \%$ ) and tied ridges (24.10\%) (Table A3.6). 39.39\% Of the interviewees (mainly men) did not invest in these technologies, $25.76 \%$ invested between $0-50 \$$ (Table A3.7). 17.65\% Used their own savings to finance these investments (Table A3.8), but for $70.59 \%$ this question was not applicable probably due to the fact that they do not investment in this activity $33.82 \%$ of the respondents mentioned not to perceive any risk, $17.65 \%$ experience injuries when digging pitches and ridges (Table A3.9). No recommendations were made to support this activity (Table A3.10).

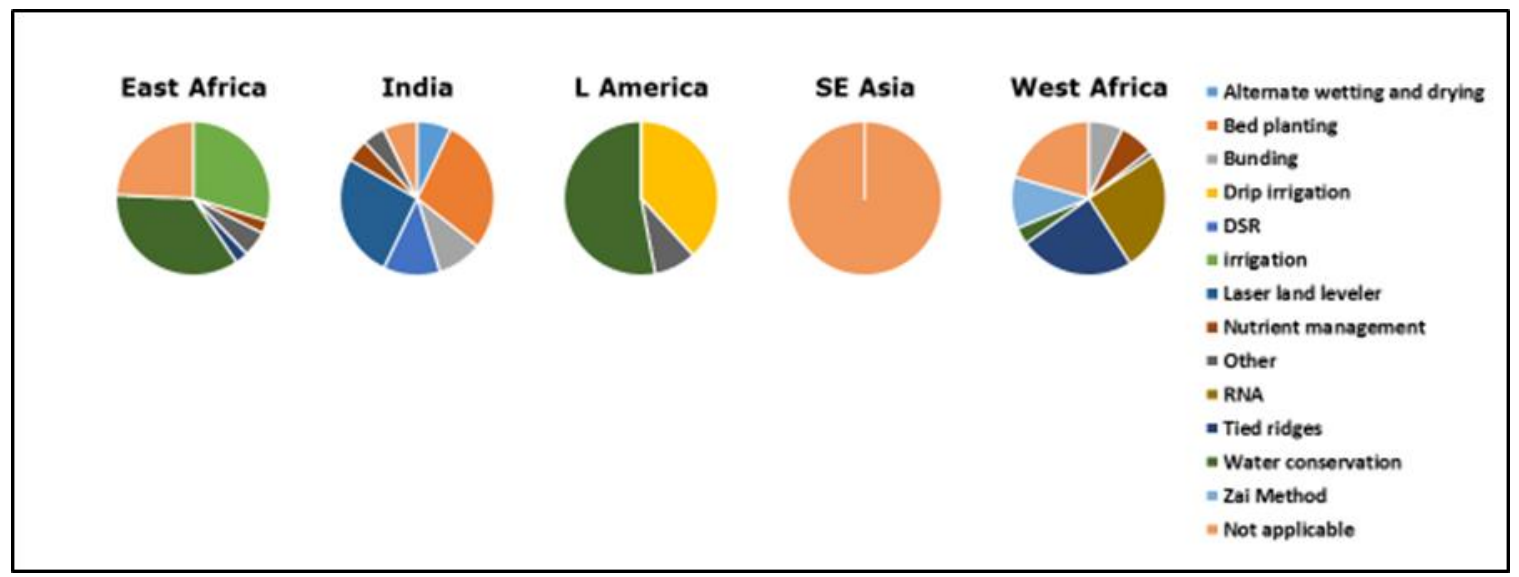

Figure 9: Water use efficiency or water conservation technologies and practices

\subsubsection{Weather forecasting services and/or index based insurance}

Results are presented in Figure 10 and tables A3.11 -A3.15 in Annex 3.

For women in East Africa radio appears a popular means for receiving weather related information.

For $77.14 \%$ of the respondents the question about the use of weather forecasting services and/or indexbased insurance was not applicable (Table A3.11). 14.29\% Of the interviewees invested between 0-50\$ in weather forecasting services and/or index based insurance (Table A3.12), for which they used the merrygo-round system (or any other informal saving network), their own savings or remittances funds (Table A3.13). However, $85.71 \%$ of the respondents perceived the question on investment as not applicable. Amongst the mentioned risks affecting this climate smart activity, wrong weather prediction was the most frequently cited by men and women. (Table A3.14). More training and subsidy were recommended to facilitate the use of weather forecasting services and/or index based insurance (Table A3.15). 
For India farmers make use of diverse weather forecasting services, but predominantly the agro advisory service (by $21.62 \%$ of the respondents), SMS service (by $21.62 \%$ ) and internet (by $21.62 \%$ ). Women appear to ask neighbours for weather forecast information(Table A3.11). Respondents (24.32\%) with a crop insurance are all male. $27.78 \%$ Males invested between 0-50 \$, 5.56\% between 50-100\$ and 5.56\% between 500-1000\$ (Table A3.12), for which they used a loan from a bank or their own savings (Table A3.13). Women however did not invest in this activity last year. $72.22 \%$ of the respondents do not perceive any risk involved (Table A3.14) and the majority did not suggest any changes to support this weather smart activity. Only relatively few men recommended a lower interest rate (Table A3.15).

For Latin America $85.71 \%$ of the respondents do not use weather forecasting services and/or index based insurance(Table A3.11).. None of the respondents invested in weather forecasting services or cop insurance last year(Table A3.12), Respondents suggested free weather forecast to facilitate this activity (Table A3.15).

For Southeast Asia the majority of the respondents (59.90\%) use TV as weather forecasting services and $13.64 \%$ use internet (Table A3.11). None of the respondents mentioned that they invested in weather forecast or cop insurance (Table A3.12).

In West Africa $36.36 \%$ of the respondents noted that they use weather forecasting services and/or index based insurance. The majority (both men and women) received weather forecast information from the agro advisory service (Table A3.11). 14.29\% Invested 0-50\$ in this activity last year. The majority, however, did not spend any money on this activity (Table A3.12). Amongst the risk options provided, wrong weather prediction was most frequently brought up (by $28.57 \%$ of the respondents). However, $27.94 \%$ of the interviewees do not perceive any risk and for $33.82 \%$ the question about risk was not applicable (Table A3.14). Flexible loans, low interest rates and more location specific forecasts were recommended changes suggested by relatively few respondents (Table A3.15).

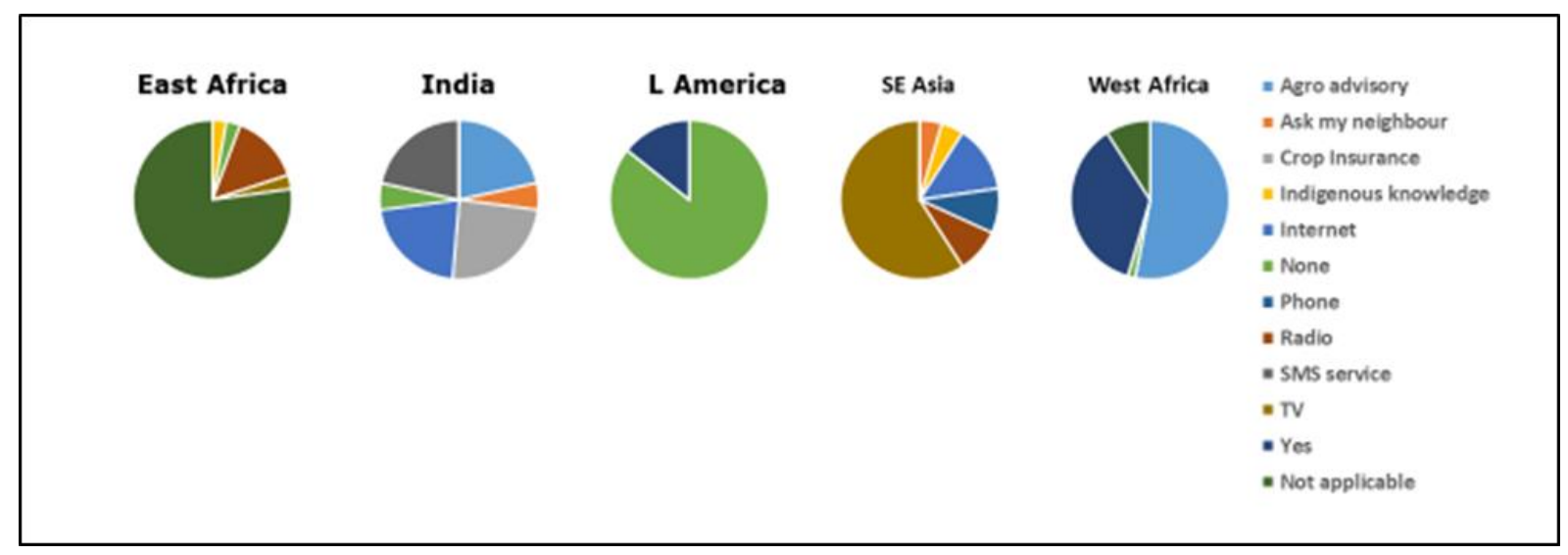

Figure 10: Weather forecasting services and/or index based insurance used/in use

\subsubsection{Nutrient management technologies and practices}

Results are presented in Figure 11 and tables A3.16 -A3.20 in Annex 3.

For East Africa, $29.82 \%$ of the respondents apply manure to improve soil fertility, $28.07 \%$ (mainly men) use chemical fertilizers and $7.02 \%$ crop residues on top soils. Women appear to prefer to apply manure for improving soil fertility and structure (Table A3.16). $62.86 \%$ of the farmers invested $0-50 \$$ in nutrient management last year (Table A3.17) for which they (especially women) used a merry-go-round/informal saving network (21.43\% of the respondents) and input supplier as financial source (14.29\%) (Table A3.18). In terms of risk factors influencing this climate smart activity, $16.22 \%$ of the respondents perceived drought as risk and $13.51 \%$ the high costs involved (Table A3.19). In order to facilitate this climate smart 
activity, $27.27 \%$ of the respondents suggested more training activities and $22.73 \%$ proposed lower interest rates (Table A3.20).

For India, $29.41 \%$ of the respondents apply integrated nutrient management practices. The Green Seeker Crop Sensing is in use by $27.45 \%$, both by men and women. (Table A3.16). 33.33\% of the respondents invested $100-500 \$$ last year, $16.67 \% 500-1000 \$$ and $11.11 \%$ invested more than $1000 \$$.(Table A3.17) Men only made the relative larger investments, but $14.29 \%$ of the male respondents did not invest at all. $61.51 \%$ Of the farmers financed investments from their own savings and $11.11 \%$ (especially women) received a loan from a trader. (Table A3.17). Women suggested more soft loans to support this climate smart activity (Table A3.20).

In Latin America dominant nutrient management technologies and practices include: $\mathrm{PH}$ neutralization with lime (by $29.55 \%$ of the respondents), application of manure (by $27.70 \%$ ), crop residues on top soils (by $22.73 \%$ ) and $20.45 \%$ apply chemical fertilizer(Table A3.16). $42.86 \%$ Invested $100-500 \$$ and $28.57 \%$ 500-1000 \$(Table A3.17) for which respondents mainly used revenues from the sale of farm products (Table A3.18). $42.11 \%$ Of farmers see pests and diseases as risks affecting this climate smart activity and $15.79 \%$ mentioned excessive rainfall as risk factor (Table A3.19). In order to facilitate this climate smart activity, $41.18 \%$ of the respondents (mainly men) suggested having more specific funds for adaptation to climate change and $23.53 \%$ recommended lower interest rates. Women suggested subsidy on fertilizers and manure (Table A3.20).

Southeast Asia respondents perceived this question as non-applicable

For West Africa 33.33\% of the respondents (men and women) apply manure, $16.19 \%$ compost and $15.24 \%$ apply chemical fertiliser to improve soil fertility (Table A3.16). $28.79 \%$ Of the respondents invested $0-50 \$, 13.64$ invested 100-500\$ (Table A3.17). Most of the farmers for whom this question was applicable used their own savings to finance nutrient management (Table A3.18). Especially women perceive injuries during digging pitches and ridges as risks affecting this activity (Table A3.19). Out of the $52 \%$ of the respondents who considered the question on recommendations for change applicable, $18.18 \%$ did not suggest any changes, relatively few proposed lower interest rates on loans to support nutrient management (Table A3.20).

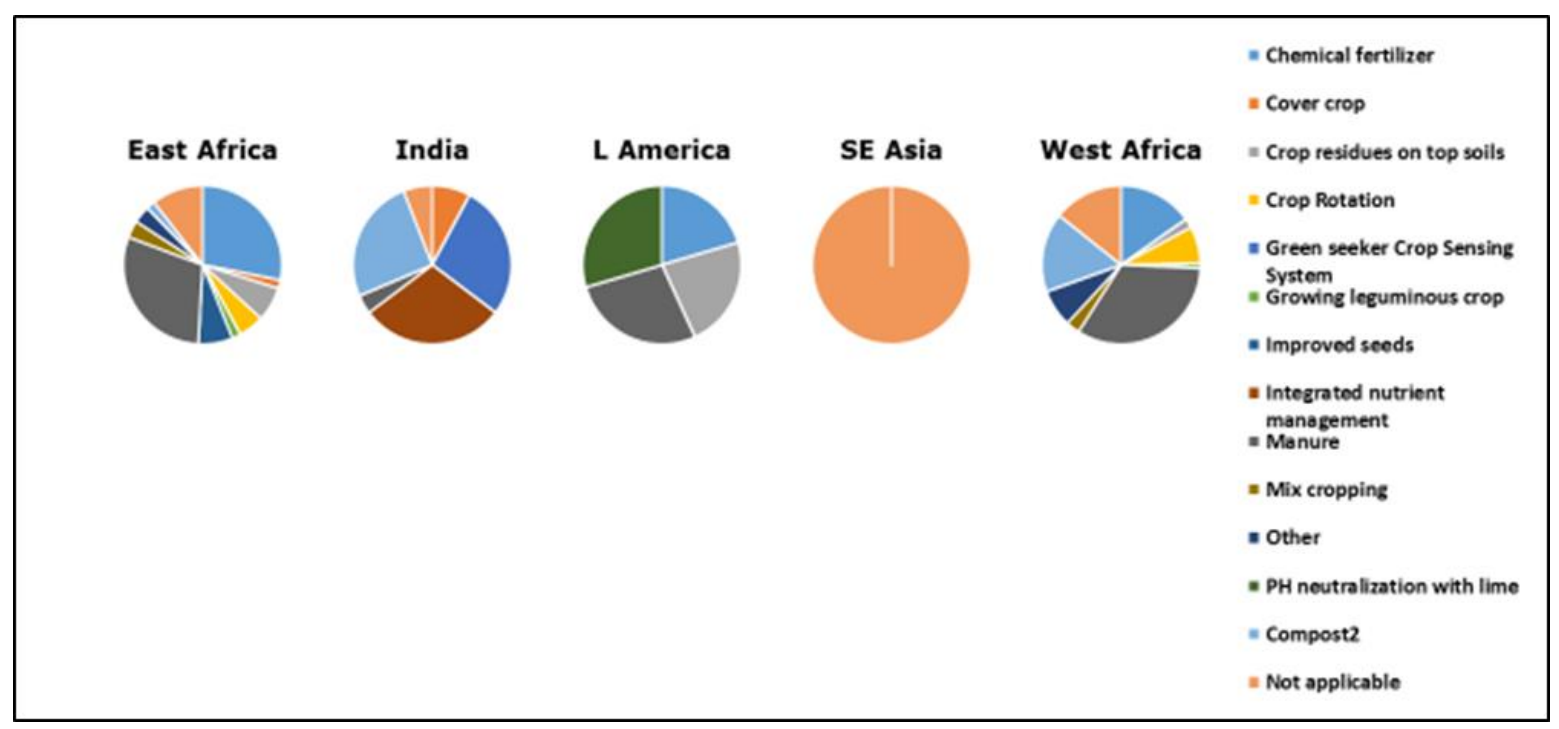

Figure 11: Nutrient management technologies and practices in applied 


\subsubsection{Other climate smart technology or practice? (e.g. agro forestry, livestock management)}

Results are presented in Figure 11 and tables A3.21 - A3.25 in Annex 3).

For East Arica other climate smart technology or practices include agroforestry (mentioned by $17.50 \%$ of the respondents, especially men), animal rearing (by $17.50 \%$, especially women), livestock management $(10.00 \%)$, tree planting $(5.00 \%)$ and others not provided in the list (Table A3.21). For the 55\% for which this question was applicable $42.86 \%$ invested $0-50 \$$ in these activities (Table A3.22) for which they mainly used the merry-go-round system or any other informal saving network (26.83\%) (Table A3.23). Major risks affecting these activities include 'not enough (stored) water (21.57\%) and pest and diseases kills animals (21.57\%) (Table A3.24). Suggestion to facilitate these other climate smart activities included training (men and women), subsidy, soft loans and lower interest (only women) (Table A3.25).

For India $72.22 \%$ of the respondents do not practice any other climate smart activity, $5.56 \%$ (men only) of the carry out agroforestry activities (Table A3.21).

For Latin America respondents carry out diverse other climate smart activities including food safety home garden (by $33.33 \%$ of the respondents, men and women), the use of drought resistant varieties $(30.30 \%$, especially by men), wind break trees (15.15\%) and climate smart cherry tomato varieties $(12.12 \%$, especially by women) (Table A3.21). $21.43 \%$ of te respondents invested $100-500 \$$ last year and $14.29 \%$ 500-1000\$. Women appear to invest relatively more in these other climate smart activities than men (Table A3.22). The CCAFS-Ecohabitats project is the main source of funding of these climate smart activities (Table A3.23). Damage from wind and rain and not enough (stored) water are seen as major risks affecting the activities (Table A3.24). Subsidy for adaptation measures to climate change with technical support and lower interest rates are preferred changes to facilitate these other climate smart activities (Table A3.25).

For Southeast Asia, all respondents practice aquaculture (Table A3.21). 60\% of the respondents (men and women) invested more than $1000 \$$ in their fish farm / aqua culture and 33.33\% between 500-1000\$ (Table A3.22) 33.33\% received a loan from a bank to finance these activities, $28.57 \%$ used their own

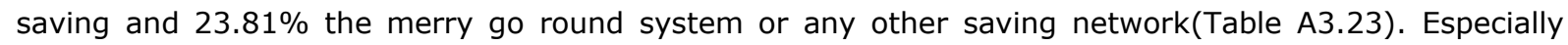
women see water pollution as a major risk affecting aquaculture (Table A3.24). 50\% Of the respondents, especially men, suggested higher loans to support fish farming/aqua culture (Table A3.25).

In West Africa, other relevant practiced climate smart activities include tree planting (by $28.09 \%$ of the respondents, men and women), agroforestry (8.99\%, mainly men) and animal rearing (by $20.22 \%$, mainly women) (Table A3.21). As to investments, 31.82\% invested between $0-50 \$$ last year, but $37.88 \%$ of the respondents did not investment in these activities at all (Table A3.22). For whom this question was applicable, $15.38 \%$ used their own revenues to finance these activities (Table A3.23). Recommendations to facilitate these other climate smart activities included training (men and women), lower interest (mainly men) and soft loans (mainly men) (Table A3.25).

For the five CCAFS regions, almost all respondents pointed out they will increase investment in CSA technologies or practices on their farm if they have (additional) access to a loan or any other financial incentive (Figure 12). 


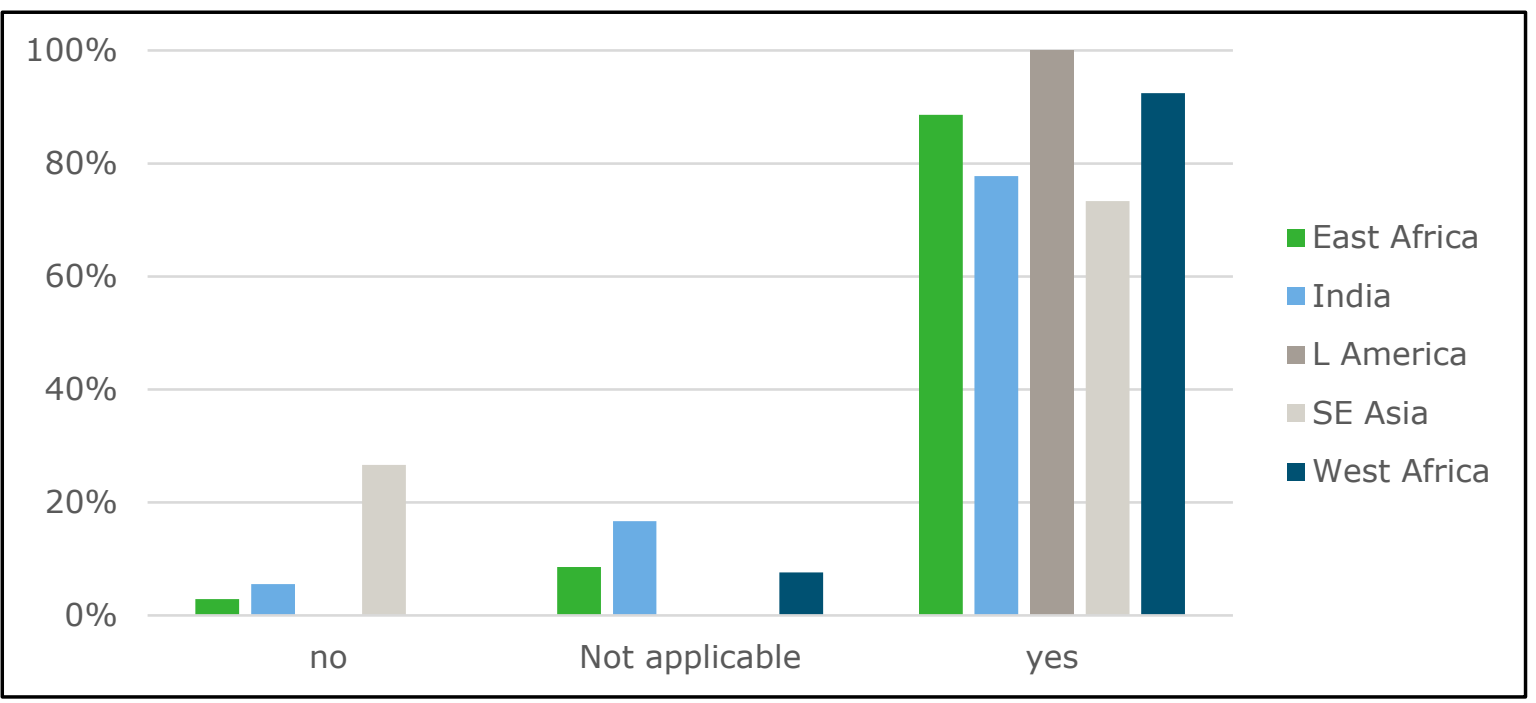

Figure 12: Willingness (\% of respondents) to invest more in CSA if farmers/SMEs had (additional) access to finance

In Latin America, Southeast Asia and West Africa, 50\% or more of the respondents (men and women) received a training in CSA technologies and practices. In East Africa and India, these figures are a bit lower. Respondents (men and women) followed slightly more trainings in agri business development than in the use of financial products and service (Figure@). In West Africa, training in agri business development seems to be more popular amongst women than men. Female Indian respondents did not receive any training in agri-business development and the use of financial products and service. Only in Southeast Asia, respondents received more training in the use of financial products and service than in agri business development.

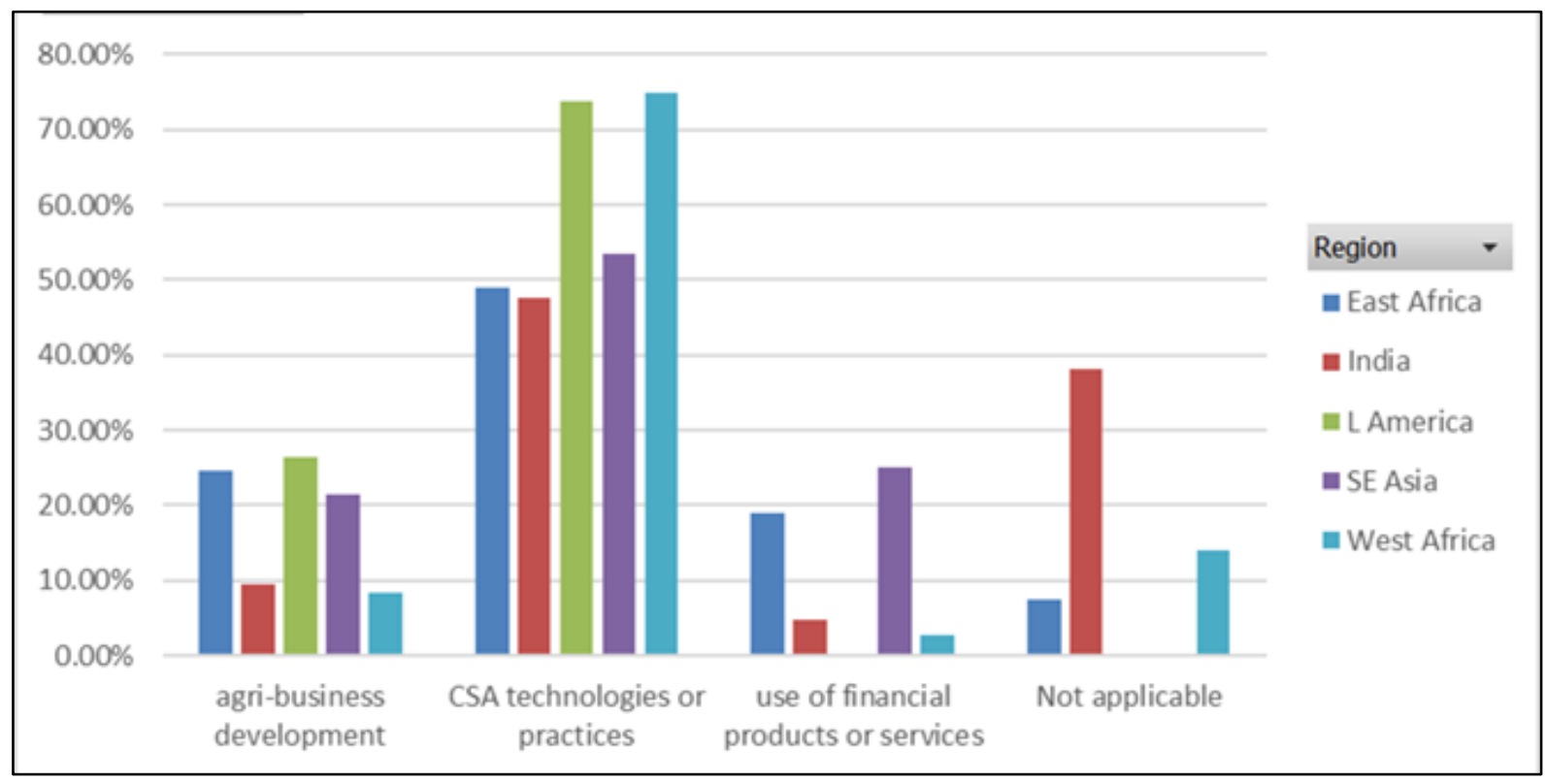

Figure 13: Training 


\section{Conclusions and perspectives}

The inventory 'demand and experiences with financial products and services', though limited and explorative, has generated first insights into farmers of climate smart villages and their awareness, access, use and demand of financial products and services' and signals critical issues in the support of climate smart agriculture technologies and practices.

\subsection{Preliminary insights into demand and experiences with financial products and services'}

The following preliminary insights can be presented in this stage:

- Financial Services for making payments: Farmers in the CCAFS regions make use of different financial service providers. Banks are relatively more frequently in use in India and Southeast Asia, Mobile Money transfer in East and west Africa and in Latin America farmers predominantly use the post office for making payments.

- Financial services for savings: Banks increase in importance for saving purposes in all regions except from Southeast Asia where farmers use more frequently SACCOs. Banks are used for saving by male and female farmers. For Indian female farmers traders are important for saving money.

- Financial services for credit/loans: The picture for receiving credit /loans is more diverse. Banks are most frequently used in Latin America, Southeast Asia and India whereas in East African farmers prefer a mobile money system and West African farmers family/friends, banks and SUSUs.

- Financial services for insurances: we see a difference in adoption between different regions. Few farmers In East Africa, West Africa and Southeast Asia use financial services to obtain an insurance. In India and Latin America, banks and insurance agencies appear to be most popular for insurance purposes.

- Important information sources: Training, self-learning, government extension services, farmers associations, SACCOs, family and friends appear to be frequently used strategies and sources for both male and female farmers to learn about financial products and services.

- Strategies to overcome financial losses: In East and West Africa selling livestock of crops to overcome financial losses appear to be a frequently used strategy for men and women to overcome finance losses due to e.g. a bad harvest or illness in the family. Borrowing money from family and friends is a popular strategy for women in Latin America.

Use of financial institutions

The percentage of respondents with a bank account vary significantly between CCAFS regions and between men and women. In India, all respondents do have a bank account, whereas in Southeast Asia only $26 \%$. In India, all female respondents have a bank account, in Latin America 86\%, but in Southeast Asia $20 \%$ of the female interviewees. Micro-finance institutions and cooperatives are also popular formal financial institutions. SACCOs are in use in East Africa and Southeast Asia. Amongst the informal ways of accessing finance, the merry go round scheme (or any other informal saving network) appears to be most frequently used in all regions, except in India where traders seem to be popular.

Farmers appear to utilise different strategies for financing farm investment. Overall, it seems that selfsupporting and not using any external source of finance is the strategy most frequently used. In the regions Latin America and East Africa, the selling of livestock or crops is an important way to create funds for farm investments. The amount of credit received last year varies largely amongst the five regions.

For the five CCAFS regions, $64 \%$ of the respondents received credit last year, 52\% of whom were women. The amount of credit taken varied significantly between the regions. Relatively large loans (1000\$) were 
taken by Indian and Southeast Asian respondents, but by males mainly. East and West Africa respondents received small amount of credits, predominantly by women.

Except from Latin America and Southeast Asia, most credits are reimbursed in a period of 3- 24 months. Repayment modalities difference between the regions. In East and West Africa most of the respondents pay back every month, whereas in India farmers pay back after harvest and in Latin America at the end of the year. Interest rates varied largely even within a particular region. Unfortunately, the interviews did not address the specific reasons for these differences. Likewise, the results do not provide insight whether women pay different interest than men for the same amount and duration of the credit. Reimbursement periods and repayment modalities also vary between regions. Detailed research is needed to better explain the reasons behind these differences. Last year's credit is predominantly used for farm investments such as crop and land management. In Southeast Asia, loans are mainly used to invest in aquaculture.

\section{Climate smart agriculture and investments}

Results on investments in climate smart agriculture technologies and practices are largely in line with the general results on access and use of financial products and services. Hereafter, we present observations on particular types of climate smart agricultural activities.

Soil conservation and land preparation activities: Farmers in East Africa, India, Latin America and West Africa apply and invest in different soil conservation and land preparation activities, for which they use diverse formal and informal financial institutions. West Africa has relatively the highest percentage of respondents who do not invest in climate smart agriculture technologies and practices. The highest investments are made by Indian farmers. Interesting is the use of remittance funds by women in East Africa to finance soil conservation and land preparation activities and the role of traders for Indian women. Risks affecting this climate smart technology are related to pest, diseases, and high costs involved. Suggested changes in the financial products and services include training, lower interest rates on loans, more subsidy and increased opportunities to get easy access to financial services

Water use efficiency or water conservation technologies and practices: Farmers in East Africa, India, Latin America and West Africa apply and invest in different water use efficiency or water conservation technologies and practices including (drip) irrigation, bed planting, water conservation, direct seeded rice. West Africa and Latin America have relatively the highest percentage of respondents who do not invest in this climate smart agricultural activity, and again Indian farmers make relatively large investments. Noteworthy is the role of the CCAFS-Eco-habitats project that appears to be an important source of finance for Latin America respondent. Risks affecting this climate smart technology are pest, diseases, and droughts. Recommendations for financial products and services to facilitate this activity include training, lower interest rates on loans and more subsidy on adaptation.

Weather forecasting services and/or index based insurances: In India, West Africa and Southeast Asia farmers are using a range of sources to receive information on weather forecast. A high percentage of Latin American respondents do not use weather forecasting services. For a relatively high percentage of East African respondents the question on Weather forecasting services was not applicable. This might be because people do not make use of these services at all. Few Indian (male) farmers do have a crop insurance. A relatively small percentage of respondents from East Africa, India and West Africa invest small amount of money $(<50 \$)$ in this type of activity. Indian farmers do make the relatively larger investments (500\$-1000\$), however they are relatively few in number. The most frequently cited risk is 'wrong whether prediction'. Recommended changes to support this weather smart activity include training, more subsidy and more location specific forecasts.

Nutrient management technologies and practices: India, East Africa, West Africa and Southeast Asia a wide range technologies and practices are in use of which the application of manure, chemicals fertilizers and compost are amongst the most frequently cited. Larger investments are made by Indian and Latin American farmers, smaller investments (0-50\$) by East and West African farmers. Risks affecting this climate smart activity are related to droughts, pests and diseases, injuries during digging pitches and 
ridges. Suggested changes in the financial products and services include lower interest rates on loans, soft loans and more subsidy on fertilizers and manure.

Other climate smart technology or practice. In Southeast Asia, all respondents practice aquaculture. For East and West Africa, livestock and animal rearing are put forward as important other climate smart activities. In Latin America home garden and the use of drought resistance crop varieties are mentioned in particular. Larger investments $(500 \$-1000 \$,>1000 \$)$ are mainly made by Southeast Asian farmers for which they receive credit from banks, a merry go round scheme and their own revenues. Water pollution is seen as a major risk affecting aquaculture. Higher loans are suggested to facilitate aquaculture in Southeast Asia.

For the five CCAFS regions almost all respondents pointed out that, they would increase investment in diverse CSA technologies or practices on their farm if they had (additional) access to a loan or any other financial incentive. Naturally it would make sense for a respondent to be positive towards additional finance especially when the conditions are not specified (yet), so this would need further attention in order to draw proper conclusions.

\subsection{General conclusions}

Overall most of the farmers applying CSA practices (77\%), invested either very small amounts ( $<$ US\$ 100 ) or not at all. The rationale behind this cannot be found from the survey. Perhaps CSA practices do not require more investments, but it is equally possible that the farmers would have liked to invest more but were not able to or prioritised other investments or expenditures. We have also found (for example in table 4 and 10) that the use of financing through banks is quite high. An unexpected result is that the income from temporary jobs (table 4 ) is quite low.

More than half of the farmers was able to finance the CSA practices themselves, either by self-financing, or by selling assets, using remittance funds or drawing from their VSLA or merry-go-round. Approximately $8 \%$ financed it through financial institutions (banks, MFIs, SACCOs) and $14 \%$ from trade-related sources (traders, shopkeepers, ESSOKO, savings collectors).

The financial profiles differ for soil practices, water practices, weather-practices, nutrient practices and other practices. Although the average amounts and sources of financing differ, these differences are not significant or systematic. It would seem that the differences in financial profiles between individual practices are more significant than the differences between types of practices. Furthermore the influence of specific context is quite strong (location, available services and institutional infrastructure).

The main suggestions from the farmers, in order to enhance the application of CSA practices, can be grouped into the following categories:

- Improvements to the financial product: roughly $18 \%$ of the farmers suggests improvements to the financial products, mainly related to credit. The most frequent suggestion is to have lower interest rates or soft loans, other suggestions relate to changes in the credit product (credit in kind, more flexible loans, higher amounts, easier access.

- Subsidies: roughly $11 \%$ of the farmers suggest subsidies of some kind. The suggestions range from free weather forecasts, to subsidies for fertilizer and manure, or for adaptation measures.

- Training: roughly $9 \%$ of the farmers suggests training, sometimes in general and sometimes on specific issues (irrigation, awareness creation of financial services).

- Other services: smaller numbers of farmers make other suggestions, for example more locationspecific and language-specific weather forecasts, or tractor services or market information. These suggestions are not as generalized as the other suggestions mentioned in the previous points. 



\subsection{Critical issues and future perspectives}

The survey revealed diverse critical issues in the access, awareness and use of financial services and products

Interest rate

Interest rates are not a primary focus considering access to finance. As a relatively high percentage of respondents suggest lower interest rates to facilitate climate smart technologies and practices, it could be considered to improve the understanding of diversity in credit for single and layered use of climate smart technologies and practices. We suggest to select cases and/or support projects where interest rates are further considered relevant with a focus on formal and informal financial institutions, interest rates, collateral, reimbursement and repayment periods as well as the relationships between these aspects. Furthermore such a study could design and implement a pilot in which different financial modalities can be tested

\section{Training}

All respondents involved in this survey do have a link with the CCAFS programme, which explains the high rate of those who received a training in climate smart technologies and practices. The percentage of respondents who followed a training on financial products and services as well as on business development is much lower. Considering the number of interviewees recommending more training (without specifying its subject), the selection of case studies/support should be informed by opportunities to:

- Include capacity building of smallholder farmers in the use of financial products and services, and business development;

- Include capacity building of managers of financial institutes in climate change and climate smart agriculture related risks on investments;

- Develop and test training/capacity building material.

Insight into costs and benefits of climate smart agriculture technologies and practices

An issue indirectly emerging from the survey is the need to have insight into (economic/social) costs and benefits of (a mix of) climate smart agriculture technologies and practices. Formal and informal financial institutions as well as farmers who want to borrow money for investing in climate smart agriculture technologies and practices need to know the added value of these technologies and practices as well as the risks involved.

For the selection of future cases and/or support of the granted projects in the call of the Food \& Business Global Challenges Programme, we suggest to select cases and/or support projects were in addition to knowledge generation on financial products and services, insights into (economic /social) costs and benefits of climate smart agriculture technologies and practices will be developed as well. 


\section{References}

Long, T. B., et al. (2016). "Barriers to the adoption and diffusion of technological innovations for climate smart agriculture in Europe: evidence from the Netherlands, France, Switzerland and Italy." Journal of Cleaner Production 112: 9-21.

Steenwerth, K.L., Hodson, A.K., Bloom, A.J., Carter, M.R., Cattaneo, A., Chartres, C.J., Hatfield, J.L., Henry, K., Hopmans, J.W., Horwath, W.R. and Jenkins, B.M., 2014. Climate smart agriculture global research agenda: scientific basis for action. Agriculture \& Food Security, 3(1), p.11.

Wattel C. and M. van Asseldonk (2017). Financial service supply with potential for supporting climate smart agriculture. Working Paper. Wageningen Economic Research - CGIAR Research Program on Climate Change, Agriculture and Food Security (CCAFS), the Netherlands.

Westermann, O., Thornton, P.K. and Förch, W. (2015). Reaching more farmers: Innovative approaches to scaling up climate smart agriculture. 


\section{Annex 1 Granted projects Food \& Business Global Challenges Programme (CCAFS)}

\begin{abstract}
Title granted project
Inclusive and climate smart business models in Ethiopian and Kenyan dairy value chains
\end{abstract}

'Business models Ethiopian and Kenyan dairy chains' - This research aims to describe business models of chain actors and supporters to identify opportunities for scaling up good climate smart practices. It is linked to "Nationally Appropriate Mitigation Actions" (NAMA) in Kenya to reduce GHG emissions from dairy production. Six dairy value chain case studies will be purposely selected, three in Kenya and three in Ethiopia, with varying degrees of market-orientation. Three PhD students will be lead investigator, each in two selected chains.

Understanding and scaling Organizational structures for SMAllholder RElisience (OSMARE) in Malawi, Mozambique, Tanzania, Zambia and Zimbabwe

Upscaling CSA with small-scale food producers organised via VSLAs: Financing for adoption, behavioural change and resilience in rural Iringa Region, Tanzania

Multiple pathways and inclusive low emission development: navigating towards leverage points in the East-African dairy sector

Understanding and improving scaling readiness of climate smart, nutrient management decision support tools (DST) in different institutional environments: Ethiopia \& Tanzania
'Understanding and scaling Organisations for SMAllholder REsilience' - This project seeks to understand when and how the organization of new business models linking farmers to markets leads to resilience of smallholders, in particular youth and women. Resilience will be assessed in terms of development of farmers' adaptive capacity and their engagement with other stakeholders in the system. During and after the investigation, personal and group trainings will provide spaces for smallholders, their representatives and stakeholders to exchange knowledge and reciprocally foster their capacities.

Upscaling climate smart agriculture via micro finance' - The smallscale agriculture sector and food systems in rural Tanzania are in critical need of investment towards Climate smart Agriculture (CSA) that satisfy criteria of sustainability, profitability, equity and resilience (SUPER). This project will provide practical and conceptual insight in the appropriate combinations of business training (through Farmer Field \& Business Schools - FFBS) and financial services (through Village Savings \& Loans Associations - VSLA) that support community-based adaptation (CBA) action plans.

'Inclusive Low-Emission Development (i-LED): East African dairy' Reducing emissions intensity of livestock is high on the agenda in East Africa. This research analyses institutional conditions for scaling inclusive Low-Emission Development (i-LED) interventions that account for the diversity of practices, development pathways and interests in the Kenyan and Tanzanian dairy sectors. The project engages governments, leading dairy firms, service providers and male and female livestock keepers in research-driven dialogues to design a portfolio of context-sensitive LED-approaches reducing emissions intensity while enhancing socio-economic inclusivity. 'Scaling climate smart nutrient management tools in Africa' - This project aims to improve the delivery and uptake of nutrient management advisory tools that aim to increase African maize production while avoiding increases in greenhouse gas emissions. Working directly with different types of farmers and advisory services, the project examines the 'user logics' and institutional environments that affect the large-scale uptake of these climate smart nutrient management advisory tools by smallholder farmers in Ethiopia and Tanzania. 
Citizen's Science approach to climate smart and nutrition sensitive seed value chains for food and nutrition security in Uganda and Ethiopia
'Citizen's Science for climate smart nutritious varieties' Traditionally new varieties of crops are being tested by agricultural scientists, with farmers, in controlled trials. In 'citizen science' samples of candidate varieties are send to a large group of farmers. They test the candidate varieties and provide simple feedback on its performance. This project will bring 'citizen science' into use in variety testing and registration in Ethiopia and Uganda. Focus will be on selection of varieties with high nutritional value adapted to climate stress.
Promoting climate resilient seed varieties: Smallholder barriers to adoption and willingness to pay for seed of drought tolerant maize varieties in Uganda

'Promoting climate resilient maize varieties in Uganda' - The uptake of certified maize seed by smallholder farmers is persistently low despite the fact that this seed has much higher yield potential and is often more tolerant to drought than the varieties traditionally grown by farmers. This project investigates the main sources of risk for smallholder farmers, and whether offering appropriate insurance products together with maize seed will increase their willingness to pay for drought tolerant maize varieties.

Using Climate Smart Financial Diaries for Scaling in the Nyando Basin, Kenya
'Climate smart Financial Diaries for Scaling in Kenya' - Nyando Basin in western Kenya experiences agricultural stagnation, environmental degradation and deepening poverty, aggravated by climate change. Previous CCAFS-projects identified the combination drought-resistant breeds of goats/horticulture/agroforestry as a promising strategy that is climate-resilient and climate smart in closing nutrient cycles. This project will support upscaling this business model addressing three challenges: (1) designing a conducive financial environment, (2) identifying additional value chain partners, and (3) identifying constraints, opportunities and required policy interventions at landscape level. 


\section{Annex 2 Survey results (part 1)}

Table A2.1: Financial institutions used for transfer of money (disaggregated by gender)

\begin{tabular}{|c|c|c|c|c|c|c|}
\hline Row Labels & East Africa & India & $\begin{array}{l}\mathrm{L} \\
\text { America }\end{array}$ & SE Asia & West Africa & $\begin{array}{l}\text { Grand } \\
\text { Total }\end{array}$ \\
\hline Bank & $2.78 \%$ & $52.94 \%$ & $11.76 \%$ & $38.89 \%$ & $32.31 \%$ & $29.79 \%$ \\
\hline female & $100.00 \%$ & $16.67 \%$ & $100.00 \%$ & $42.86 \%$ & $61.90 \%$ & $50.00 \%$ \\
\hline male & $0.00 \%$ & $83.33 \%$ & $0.00 \%$ & $57.14 \%$ & $38.10 \%$ & $50.00 \%$ \\
\hline Family/Friends & $0.00 \%$ & $41.18 \%$ & $5.88 \%$ & $27.78 \%$ & $10.00 \%$ & $14.04 \%$ \\
\hline female & & $35.71 \%$ & $100.00 \%$ & $20.00 \%$ & $61.54 \%$ & $45.45 \%$ \\
\hline male & & $64.29 \%$ & $0.00 \%$ & $80.00 \%$ & $38.46 \%$ & $54.55 \%$ \\
\hline Mobile Money & $97.22 \%$ & $2.94 \%$ & $0.00 \%$ & $0.00 \%$ & $56.92 \%$ & $46.81 \%$ \\
\hline female & $54.29 \%$ & $0.00 \%$ & & & $41.89 \%$ & $45.45 \%$ \\
\hline male & $45.71 \%$ & $100.00 \%$ & & & $58.11 \%$ & $54.55 \%$ \\
\hline Post office & $0.00 \%$ & $0.00 \%$ & $82.35 \%$ & $0.00 \%$ & $0.00 \%$ & $5.96 \%$ \\
\hline female & & & $85.71 \%$ & & & $85.71 \%$ \\
\hline male & & & $14.29 \%$ & & & $14.29 \%$ \\
\hline Trader & $0.00 \%$ & $2.94 \%$ & $0.00 \%$ & $0.00 \%$ & $0.00 \%$ & $0.43 \%$ \\
\hline male & & $100.00 \%$ & & & & $100.00 \%$ \\
\hline Not applicable & $0.00 \%$ & $0.00 \%$ & $0.00 \%$ & $33.33 \%$ & $0.77 \%$ & $2.98 \%$ \\
\hline female & & & & $33.33 \%$ & $100.00 \%$ & $42.86 \%$ \\
\hline male & & & & $66.67 \%$ & $0.00 \%$ & $57.14 \%$ \\
\hline Grand Total & $100.00 \%$ & $100.00 \%$ & $100.00 \%$ & $100.00 \%$ & $100.00 \%$ & $100.00 \%$ \\
\hline
\end{tabular}

Table A.2: Financial institutions used for savings, disaggregated by gender

\begin{tabular}{|c|c|c|c|c|c|c|}
\hline Row Labels & East Africa & India & L America & SE Asia & $\begin{array}{l}\text { West } \\
\text { Africa }\end{array}$ & $\begin{array}{l}\text { Grand } \\
\text { Total }\end{array}$ \\
\hline Bank & $30.61 \%$ & $58.06 \%$ & $83.33 \%$ & $12.50 \%$ & $34.78 \%$ & $39.30 \%$ \\
\hline female & $53.33 \%$ & $22.22 \%$ & $80.00 \%$ & $0.00 \%$ & $47.50 \%$ & $47.78 \%$ \\
\hline male & $46.67 \%$ & $77.78 \%$ & $20.00 \%$ & $100.00 \%$ & $52.50 \%$ & $52.22 \%$ \\
\hline Cooperative & $0.00 \%$ & $0.00 \%$ & $11.11 \%$ & $0.00 \%$ & $0.00 \%$ & $0.87 \%$ \\
\hline female & & & $100.00 \%$ & & & $100.00 \%$ \\
\hline family/friends & $4.08 \%$ & $35.48 \%$ & $5.56 \%$ & $0.00 \%$ & $18.26 \%$ & $15.28 \%$ \\
\hline female & $100.00 \%$ & $18.18 \%$ & $100.00 \%$ & & $33.33 \%$ & $34.29 \%$ \\
\hline male & $0.00 \%$ & $81.82 \%$ & $0.00 \%$ & & $66.67 \%$ & $65.71 \%$ \\
\hline Informal saving network & $0.00 \%$ & $0.00 \%$ & $0.00 \%$ & $31.25 \%$ & $0.00 \%$ & $2.18 \%$ \\
\hline female & & & & $20.00 \%$ & & $20.00 \%$ \\
\hline male & & & & $80.00 \%$ & & $80.00 \%$ \\
\hline MFI & $2.04 \%$ & $0.00 \%$ & $0.00 \%$ & $0.00 \%$ & $7.83 \%$ & $4.37 \%$ \\
\hline female & $100.00 \%$ & & & & $44.44 \%$ & $50.00 \%$ \\
\hline male & $0.00 \%$ & & & & $55.56 \%$ & $50.00 \%$ \\
\hline Mobile Money & $48.98 \%$ & $0.00 \%$ & $0.00 \%$ & $0.00 \%$ & $9.57 \%$ & $15.28 \%$ \\
\hline female & $54.17 \%$ & & & & $63.64 \%$ & $57.14 \%$ \\
\hline male & $45.83 \%$ & & & & $36.36 \%$ & $42.86 \%$ \\
\hline SACCO & $0.00 \%$ & $0.00 \%$ & $0.00 \%$ & $0.00 \%$ & $0.87 \%$ & $0.44 \%$ \\
\hline
\end{tabular}




\begin{tabular}{|c|c|c|c|c|c|c|}
\hline female & & & & & $100.00 \%$ & $100.00 \%$ \\
\hline SUSU & $0.00 \%$ & $0.00 \%$ & $0.00 \%$ & $0.00 \%$ & $22.61 \%$ & $11.35 \%$ \\
\hline female & & & & & $57.69 \%$ & $57.69 \%$ \\
\hline male & & & & & $42.31 \%$ & $42.31 \%$ \\
\hline trader & $0.00 \%$ & $6.45 \%$ & $0.00 \%$ & $0.00 \%$ & $0.00 \%$ & $0.87 \%$ \\
\hline female & & $100.00 \%$ & & & & $100.00 \%$ \\
\hline VSLA & $6.12 \%$ & $0.00 \%$ & $0.00 \%$ & $0.00 \%$ & $4.35 \%$ & $3.49 \%$ \\
\hline female & $100.00 \%$ & & & & $20.00 \%$ & $50.00 \%$ \\
\hline male & $0.00 \%$ & & & & $80.00 \%$ & $50.00 \%$ \\
\hline Not applicable & $8.16 \%$ & $0.00 \%$ & $0.00 \%$ & $56.25 \%$ & $1.74 \%$ & $6.55 \%$ \\
\hline female & $50.00 \%$ & & & $44.44 \%$ & $0.00 \%$ & $40.00 \%$ \\
\hline male & $50.00 \%$ & & & $55.56 \%$ & $100.00 \%$ & $60.00 \%$ \\
\hline Grand Total & $100.00 \%$ & $100.00 \%$ & $100.00 \%$ & $100.00 \%$ & $100.00 \%$ & $100.00 \%$ \\
\hline
\end{tabular}

Table A2.3: Sources used for credit, disaggregated by gender

\begin{tabular}{|c|c|c|c|c|c|c|}
\hline Row Labels & East Africa & India & L America & SE Asia & $\begin{array}{l}\text { West } \\
\text { Africa }\end{array}$ & $\begin{array}{l}\text { Grand } \\
\text { Total }\end{array}$ \\
\hline Bank & $16.67 \%$ & $35.90 \%$ & $82.35 \%$ & $48.15 \%$ & $25.47 \%$ & $32.07 \%$ \\
\hline female & $87.50 \%$ & $0.00 \%$ & $85.71 \%$ & $23.08 \%$ & $44.44 \%$ & $44.74 \%$ \\
\hline male & $12.50 \%$ & $100.00 \%$ & $14.29 \%$ & $76.92 \%$ & $55.56 \%$ & $55.26 \%$ \\
\hline Business partners & $4.17 \%$ & $0.00 \%$ & $0.00 \%$ & $0.00 \%$ & $0.00 \%$ & $0.84 \%$ \\
\hline male & $100.00 \%$ & & & & & $100.00 \%$ \\
\hline Cooperative & $2.08 \%$ & $2.56 \%$ & $5.88 \%$ & $0.00 \%$ & $0.00 \%$ & $1.27 \%$ \\
\hline female & $100.00 \%$ & $0.00 \%$ & $100.00 \%$ & & & $66.67 \%$ \\
\hline male & $0.00 \%$ & $100.00 \%$ & $0.00 \%$ & & & $33.33 \%$ \\
\hline Family/Friends & $6.25 \%$ & $20.51 \%$ & $11.76 \%$ & $7.41 \%$ & $26.42 \%$ & $18.14 \%$ \\
\hline female & $66.67 \%$ & $50.00 \%$ & $100.00 \%$ & $0.00 \%$ & $39.29 \%$ & $44.19 \%$ \\
\hline male & $33.33 \%$ & $50.00 \%$ & $0.00 \%$ & $100.00 \%$ & $60.71 \%$ & $55.81 \%$ \\
\hline Informal saving network & $2.08 \%$ & $0.00 \%$ & $0.00 \%$ & $37.04 \%$ & $0.00 \%$ & $4.64 \%$ \\
\hline female & $100.00 \%$ & & & $40.00 \%$ & & $45.45 \%$ \\
\hline male & $0.00 \%$ & & & $60.00 \%$ & & $54.55 \%$ \\
\hline MFI & $6.25 \%$ & $0.00 \%$ & $0.00 \%$ & $0.00 \%$ & $10.38 \%$ & $5.91 \%$ \\
\hline female & $66.67 \%$ & & & & $45.45 \%$ & $50.00 \%$ \\
\hline male & $33.33 \%$ & & & & $54.55 \%$ & $50.00 \%$ \\
\hline Mobile Money & $31.25 \%$ & $0.00 \%$ & $0.00 \%$ & $0.00 \%$ & $0.94 \%$ & $6.75 \%$ \\
\hline female & $53.33 \%$ & & & & $0.00 \%$ & $50.00 \%$ \\
\hline male & $46.67 \%$ & & & & $100.00 \%$ & $50.00 \%$ \\
\hline moneylender & $0.00 \%$ & $7.69 \%$ & $0.00 \%$ & $0.00 \%$ & $5.66 \%$ & $3.80 \%$ \\
\hline female & & $33.33 \%$ & & & $16.67 \%$ & $22.22 \%$ \\
\hline male & & $66.67 \%$ & & & $83.33 \%$ & $77.78 \%$ \\
\hline SACCO & $8.33 \%$ & $0.00 \%$ & $0.00 \%$ & $0.00 \%$ & $0.94 \%$ & $2.11 \%$ \\
\hline female & $50.00 \%$ & & & & $100.00 \%$ & $60.00 \%$ \\
\hline male & $50.00 \%$ & & & & $0.00 \%$ & $40.00 \%$ \\
\hline SUSU & $0.00 \%$ & $0.00 \%$ & $0.00 \%$ & $0.00 \%$ & $23.58 \%$ & $10.55 \%$ \\
\hline female & & & & & $56.00 \%$ & $56.00 \%$ \\
\hline male & & & & & $44.00 \%$ & $44.00 \%$ \\
\hline Trader & $0.00 \%$ & $33.33 \%$ & $0.00 \%$ & $0.00 \%$ & $0.00 \%$ & $5.49 \%$ \\
\hline female & & $30.77 \%$ & & & & $30.77 \%$ \\
\hline
\end{tabular}




\begin{tabular}{|c|c|c|c|c|c|c|}
\hline male & & $69.23 \%$ & & & & $69.23 \%$ \\
\hline VSLA & $14.58 \%$ & $0.00 \%$ & $0.00 \%$ & $0.00 \%$ & $1.89 \%$ & $3.80 \%$ \\
\hline female & $100.00 \%$ & & & & $0.00 \%$ & $77.78 \%$ \\
\hline male & $0.00 \%$ & & & & $100.00 \%$ & $22.22 \%$ \\
\hline Not applicable & $8.33 \%$ & $0.00 \%$ & $0.00 \%$ & $7.41 \%$ & $4.72 \%$ & $4.64 \%$ \\
\hline female & $0.00 \%$ & & & $0.00 \%$ & $20.00 \%$ & $9.09 \%$ \\
\hline male & $100.00 \%$ & & & $100.00 \%$ & $80.00 \%$ & $90.91 \%$ \\
\hline Grand Total & $100.00 \%$ & $100.00 \%$ & $100.00 \%$ & $100.00 \%$ & $100.00 \%$ & $100.00 \%$ \\
\hline
\end{tabular}

Table A2.3: Sources used for insurance, disaggregated by gender

\begin{tabular}{|c|c|c|c|c|c|c|}
\hline Row Labels & East Africa & India & $\begin{array}{l}\text { L } \\
\text { America }\end{array}$ & SE Asia & $\begin{array}{l}\text { West } \\
\text { Africa }\end{array}$ & $\begin{array}{l}\text { Grand } \\
\text { Total }\end{array}$ \\
\hline Bank & $27.03 \%$ & $36.36 \%$ & $26.67 \%$ & $0.00 \%$ & $1.23 \%$ & $14.92 \%$ \\
\hline female & $20.00 \%$ & $16.67 \%$ & $75.00 \%$ & & $0.00 \%$ & $25.93 \%$ \\
\hline male & $80.00 \%$ & $83.33 \%$ & $25.00 \%$ & & $100.00 \%$ & $74.07 \%$ \\
\hline Cooperative & $2.70 \%$ & $3.03 \%$ & $20.00 \%$ & $0.00 \%$ & $0.00 \%$ & $2.76 \%$ \\
\hline female & $0.00 \%$ & $0.00 \%$ & $100.00 \%$ & & & $60.00 \%$ \\
\hline male & $0.00 \%$ & $100.00 \%$ & $0.00 \%$ & & & $20.00 \%$ \\
\hline (blank) & $100.00 \%$ & $0.00 \%$ & $0.00 \%$ & & & $20.00 \%$ \\
\hline Government organization & $0.00 \%$ & $27.27 \%$ & $0.00 \%$ & $0.00 \%$ & $0.00 \%$ & $4.97 \%$ \\
\hline female & & $33.33 \%$ & & & & $33.33 \%$ \\
\hline male & & $66.67 \%$ & & & & $66.67 \%$ \\
\hline Insurance Company & $16.22 \%$ & $30.30 \%$ & $33.33 \%$ & $20.00 \%$ & $38.27 \%$ & $30.39 \%$ \\
\hline female & $100.00 \%$ & $10.00 \%$ & $80.00 \%$ & $33.33 \%$ & $51.61 \%$ & $50.91 \%$ \\
\hline male & $0.00 \%$ & $90.00 \%$ & $20.00 \%$ & $66.67 \%$ & $48.39 \%$ & $49.09 \%$ \\
\hline MFI & $0.00 \%$ & $0.00 \%$ & $0.00 \%$ & $0.00 \%$ & $1.23 \%$ & $0.55 \%$ \\
\hline female & & & & & $100.00 \%$ & $100.00 \%$ \\
\hline Mobile Money & $8.11 \%$ & $0.00 \%$ & $0.00 \%$ & $0.00 \%$ & $4.94 \%$ & $3.87 \%$ \\
\hline female & $66.67 \%$ & & & & $100.00 \%$ & $85.71 \%$ \\
\hline male & $33.33 \%$ & & & & $0.00 \%$ & $14.29 \%$ \\
\hline SACCO & $0.00 \%$ & $0.00 \%$ & $0.00 \%$ & $0.00 \%$ & $13.58 \%$ & $6.08 \%$ \\
\hline female & & & & & $36.36 \%$ & $36.36 \%$ \\
\hline male & & & & & $63.64 \%$ & $63.64 \%$ \\
\hline Not applicable & $45.95 \%$ & $3.03 \%$ & $20.00 \%$ & $80.00 \%$ & $40.74 \%$ & $36.46 \%$ \\
\hline female & $58.82 \%$ & $100.00 \%$ & $100.00 \%$ & $33.33 \%$ & $33.33 \%$ & $43.94 \%$ \\
\hline male & $41.18 \%$ & $0.00 \%$ & $0.00 \%$ & $66.67 \%$ & $66.67 \%$ & $56.06 \%$ \\
\hline Grand Total & $100.00 \%$ & $100.00 \%$ & $100.00 \%$ & $100.00 \%$ & $100.00 \%$ & $100.00 \%$ \\
\hline
\end{tabular}

Table A2.4: Sources used to improve knowledge about financial products and services, disaggregated by gender

\begin{tabular}{|c|c|c|c|c|c|c|}
\hline Source of information & East Africa & India & $\begin{array}{l}\text { L } \\
\text { America }\end{array}$ & SE Asia & $\begin{array}{l}\text { West } \\
\text { Africa }\end{array}$ & $\begin{array}{l}\text { Grand } \\
\text { Total }\end{array}$ \\
\hline Bank & $0.86 \%$ & $14.89 \%$ & $0.00 \%$ & $11.11 \%$ & $2.27 \%$ & $3.97 \%$ \\
\hline female & $100.00 \%$ & $14.29 \%$ & & $50.00 \%$ & $75.00 \%$ & $43.75 \%$ \\
\hline male & $0.00 \%$ & $85.71 \%$ & & $50.00 \%$ & $25.00 \%$ & $56.25 \%$ \\
\hline CCAFs Agent & $0.00 \%$ & $0.00 \%$ & $0.00 \%$ & $0.00 \%$ & $1.70 \%$ & $0.74 \%$ \\
\hline female & & & & & $66.67 \%$ & $66.67 \%$ \\
\hline male & & & & & $33.33 \%$ & $33.33 \%$ \\
\hline Community members & $1.72 \%$ & $14.89 \%$ & $0.00 \%$ & $5.56 \%$ & $5.68 \%$ & $5.21 \%$ \\
\hline
\end{tabular}




\begin{tabular}{|c|c|c|c|c|c|c|}
\hline female & $100.00 \%$ & $14.29 \%$ & & $100.00 \%$ & $50.00 \%$ & $47.62 \%$ \\
\hline male & $0.00 \%$ & $85.71 \%$ & & $0.00 \%$ & $50.00 \%$ & $52.38 \%$ \\
\hline Development partners & $4.31 \%$ & $2.13 \%$ & $0.00 \%$ & $0.00 \%$ & $9.09 \%$ & $5.46 \%$ \\
\hline female & $40.00 \%$ & $0.00 \%$ & & & $37.50 \%$ & $36.36 \%$ \\
\hline male & $60.00 \%$ & $100.00 \%$ & & & $62.50 \%$ & $63.64 \%$ \\
\hline Extension agent & $5.17 \%$ & $0.00 \%$ & $0.00 \%$ & $0.00 \%$ & $5.68 \%$ & $3.97 \%$ \\
\hline female & $66.67 \%$ & & & & $40.00 \%$ & $50.00 \%$ \\
\hline male & $33.33 \%$ & & & & $60.00 \%$ & $50.00 \%$ \\
\hline Facilitating agencies & $7.76 \%$ & $0.00 \%$ & $39.29 \%$ & $8.33 \%$ & $5.11 \%$ & $7.94 \%$ \\
\hline female & $66.67 \%$ & & $81.82 \%$ & $0.00 \%$ & $44.44 \%$ & $59.38 \%$ \\
\hline male & $33.33 \%$ & & $18.18 \%$ & $100.00 \%$ & $55.56 \%$ & $40.63 \%$ \\
\hline Farmers associations & $7.76 \%$ & $4.26 \%$ & $7.14 \%$ & $16.67 \%$ & $10.23 \%$ & $9.18 \%$ \\
\hline female & $33.33 \%$ & $0.00 \%$ & $50.00 \%$ & $33.33 \%$ & $55.56 \%$ & $43.24 \%$ \\
\hline male & $66.67 \%$ & $100.00 \%$ & $50.00 \%$ & $66.67 \%$ & $44.44 \%$ & $56.76 \%$ \\
\hline Friends/Family & $2.59 \%$ & $17.02 \%$ & $3.57 \%$ & $13.89 \%$ & $10.23 \%$ & $8.68 \%$ \\
\hline female & $66.67 \%$ & $12.50 \%$ & $100.00 \%$ & $20.00 \%$ & $38.89 \%$ & $34.29 \%$ \\
\hline male & $33.33 \%$ & $87.50 \%$ & $0.00 \%$ & $80.00 \%$ & $61.11 \%$ & $65.71 \%$ \\
\hline Government extension services & $16.38 \%$ & $8.51 \%$ & $0.00 \%$ & $0.00 \%$ & $9.09 \%$ & $9.68 \%$ \\
\hline female & $36.84 \%$ & $50.00 \%$ & & & $18.75 \%$ & $30.77 \%$ \\
\hline male & $63.16 \%$ & $50.00 \%$ & & & $81.25 \%$ & $69.23 \%$ \\
\hline Internet & $0.86 \%$ & $4.26 \%$ & $0.00 \%$ & $0.00 \%$ & $0.00 \%$ & $0.74 \%$ \\
\hline female & $0.00 \%$ & $50.00 \%$ & & & & $33.33 \%$ \\
\hline male & $100.00 \%$ & $50.00 \%$ & & & & $66.67 \%$ \\
\hline MFI & $0.86 \%$ & $0.00 \%$ & $0.00 \%$ & $0.00 \%$ & $1.14 \%$ & $0.74 \%$ \\
\hline female & $100.00 \%$ & & & & $100.00 \%$ & $100.00 \%$ \\
\hline News, magazines & $2.59 \%$ & $8.51 \%$ & $0.00 \%$ & $0.00 \%$ & $0.00 \%$ & $1.74 \%$ \\
\hline male & $100.00 \%$ & $100.00 \%$ & & & & $100.00 \%$ \\
\hline Radio & $6.90 \%$ & $4.26 \%$ & $0.00 \%$ & $0.00 \%$ & $7.95 \%$ & $5.96 \%$ \\
\hline female & $50.00 \%$ & $0.00 \%$ & & & $50.00 \%$ & $45.83 \%$ \\
\hline male & $50.00 \%$ & $100.00 \%$ & & & $50.00 \%$ & $54.17 \%$ \\
\hline SACCO & $2.59 \%$ & $0.00 \%$ & $0.00 \%$ & $16.67 \%$ & $0.00 \%$ & $2.23 \%$ \\
\hline female & $33.33 \%$ & & & $50.00 \%$ & & $44.44 \%$ \\
\hline male & $66.67 \%$ & & & $50.00 \%$ & & $55.56 \%$ \\
\hline Savings \& credit group & $6.90 \%$ & $0.00 \%$ & $0.00 \%$ & $0.00 \%$ & $2.27 \%$ & $2.98 \%$ \\
\hline female & $87.50 \%$ & & & & $50.00 \%$ & $75.00 \%$ \\
\hline male & $12.50 \%$ & & & & $50.00 \%$ & $25.00 \%$ \\
\hline School & $0.00 \%$ & $2.13 \%$ & $0.00 \%$ & $0.00 \%$ & $1.14 \%$ & $0.74 \%$ \\
\hline female & & $100.00 \%$ & & & $50.00 \%$ & $66.67 \%$ \\
\hline male & & $0.00 \%$ & & & $50.00 \%$ & $33.33 \%$ \\
\hline Self-learning & $6.03 \%$ & $4.26 \%$ & $25.00 \%$ & $22.22 \%$ & $13.07 \%$ & $11.66 \%$ \\
\hline female & $71.43 \%$ & $0.00 \%$ & $85.71 \%$ & $37.50 \%$ & $56.52 \%$ & $57.45 \%$ \\
\hline male & $28.57 \%$ & $100.00 \%$ & $14.29 \%$ & $62.50 \%$ & $43.48 \%$ & $42.55 \%$ \\
\hline SMS services & $0.86 \%$ & $4.26 \%$ & $0.00 \%$ & $0.00 \%$ & $2.84 \%$ & $1.99 \%$ \\
\hline female & $100.00 \%$ & $0.00 \%$ & & & $60.00 \%$ & $50.00 \%$ \\
\hline male & $0.00 \%$ & $100.00 \%$ & & & $40.00 \%$ & $50.00 \%$ \\
\hline Spouse & $0.86 \%$ & $2.13 \%$ & $0.00 \%$ & $0.00 \%$ & $0.57 \%$ & $0.74 \%$ \\
\hline female & $100.00 \%$ & $100.00 \%$ & & & $100.00 \%$ & $100.00 \%$ \\
\hline Traders/ middlemen & $1.72 \%$ & $4.26 \%$ & $0.00 \%$ & $0.00 \%$ & $0.57 \%$ & $1.24 \%$ \\
\hline female & $50.00 \%$ & $0.00 \%$ & & & $100.00 \%$ & $40.00 \%$ \\
\hline
\end{tabular}




\begin{tabular}{|c|c|c|c|c|c|c|}
\hline male & $50.00 \%$ & $100.00 \%$ & & & $0.00 \%$ & $60.00 \%$ \\
\hline Trainings & $22.41 \%$ & $0.00 \%$ & $25.00 \%$ & $2.78 \%$ & $9.09 \%$ & $12.41 \%$ \\
\hline female & $57.69 \%$ & & $85.71 \%$ & $0.00 \%$ & $50.00 \%$ & $58.00 \%$ \\
\hline male & $42.31 \%$ & & $14.29 \%$ & $100.00 \%$ & $50.00 \%$ & $42.00 \%$ \\
\hline Other & $0.86 \%$ & $4.26 \%$ & $0.00 \%$ & $2.78 \%$ & $0.00 \%$ & $0.99 \%$ \\
\hline female & $100.00 \%$ & $0.00 \%$ & & $0.00 \%$ & & $25.00 \%$ \\
\hline male & $0.00 \%$ & $100.00 \%$ & & $100.00 \%$ & & $75.00 \%$ \\
\hline Not applicable & $0.00 \%$ & $0.00 \%$ & $0.00 \%$ & $0.00 \%$ & $2.27 \%$ & $0.99 \%$ \\
\hline female & & & & & $50.00 \%$ & $50.00 \%$ \\
\hline male & & & & & $50.00 \%$ & $50.00 \%$ \\
\hline Grand Total & $100.00 \%$ & $100.00 \%$ & $100.00 \%$ & $100.00 \%$ & $100.00 \%$ & $100.00 \%$ \\
\hline
\end{tabular}

Table A2.5: Banks were respondents have an account, gender disaggregated

\begin{tabular}{|c|c|c|c|c|c|c|}
\hline Banks & East Africa & India & $\begin{array}{l}\mathrm{L} \\
\text { America }\end{array}$ & SE Asia & $\begin{array}{l}\text { West } \\
\text { Africa }\end{array}$ & $\begin{array}{l}\text { Grand } \\
\text { Total }\end{array}$ \\
\hline Agribank & $0.00 \%$ & $0.00 \%$ & $0.00 \%$ & $26.67 \%$ & $0.00 \%$ & $2.60 \%$ \\
\hline female & & & & $25.00 \%$ & & $25.00 \%$ \\
\hline male & & & & $75.00 \%$ & & $75.00 \%$ \\
\hline Axis bank & $0.00 \%$ & $18.18 \%$ & $0.00 \%$ & $0.00 \%$ & $0.00 \%$ & $2.60 \%$ \\
\hline female & & $25.00 \%$ & & & & $25.00 \%$ \\
\hline male & & $75.00 \%$ & & & & $75.00 \%$ \\
\hline Banco de Bogotá & $0.00 \%$ & $0.00 \%$ & $73.33 \%$ & $0.00 \%$ & $0.00 \%$ & $7.14 \%$ \\
\hline female & & & $90.91 \%$ & & & $90.91 \%$ \\
\hline male & & & $9.09 \%$ & & & $9.09 \%$ \\
\hline BBVA & $0.00 \%$ & $0.00 \%$ & $6.67 \%$ & $0.00 \%$ & $0.00 \%$ & $0.65 \%$ \\
\hline female & & & $100.00 \%$ & & & $100.00 \%$ \\
\hline CNCAS & $0.00 \%$ & $0.00 \%$ & $0.00 \%$ & $0.00 \%$ & $1.52 \%$ & $0.65 \%$ \\
\hline male & & & & & $100.00 \%$ & $100.00 \%$ \\
\hline Community bank & $0.00 \%$ & $0.00 \%$ & $0.00 \%$ & $0.00 \%$ & $1.52 \%$ & $0.65 \%$ \\
\hline female & & & & & $100.00 \%$ & $100.00 \%$ \\
\hline Coomeva & $0.00 \%$ & $0.00 \%$ & $6.67 \%$ & $0.00 \%$ & $0.00 \%$ & $0.65 \%$ \\
\hline female & & & $100.00 \%$ & & & $100.00 \%$ \\
\hline Cooperative & $2.78 \%$ & $0.00 \%$ & $0.00 \%$ & $0.00 \%$ & $0.00 \%$ & $0.65 \%$ \\
\hline female & $100.00 \%$ & & & & & $100.00 \%$ \\
\hline Crédit Mutuel du Sénégal (CMS) & $0.00 \%$ & $0.00 \%$ & $0.00 \%$ & $0.00 \%$ & $10.61 \%$ & $4.55 \%$ \\
\hline female & & & & & $14.29 \%$ & $14.29 \%$ \\
\hline male & & & & & $85.71 \%$ & $85.71 \%$ \\
\hline Credit union & $0.00 \%$ & $0.00 \%$ & $0.00 \%$ & $0.00 \%$ & $1.52 \%$ & $0.65 \%$ \\
\hline female & & & & & $100.00 \%$ & $100.00 \%$ \\
\hline Diamond Winners & $0.00 \%$ & $0.00 \%$ & $0.00 \%$ & $0.00 \%$ & $1.52 \%$ & $0.65 \%$ \\
\hline female & & & & & $100.00 \%$ & $100.00 \%$ \\
\hline Equity bank & $8.33 \%$ & $0.00 \%$ & $0.00 \%$ & $0.00 \%$ & $0.00 \%$ & $1.95 \%$ \\
\hline female & $66.67 \%$ & & & & & $66.67 \%$ \\
\hline male & $33.33 \%$ & & & & & $33.33 \%$ \\
\hline HDFC Bank & $0.00 \%$ & $13.64 \%$ & $0.00 \%$ & $0.00 \%$ & $0.00 \%$ & $1.95 \%$ \\
\hline male & & $100.00 \%$ & & & & $100.00 \%$ \\
\hline КСB & $25.00 \%$ & $0.00 \%$ & $0.00 \%$ & $0.00 \%$ & $0.00 \%$ & $5.84 \%$ \\
\hline female & $55.56 \%$ & & & & & $55.56 \%$ \\
\hline male & $44.44 \%$ & & & & & $44.44 \%$ \\
\hline KWE (KENYA WOMEN ENTERPRISE) & $2.78 \%$ & $0.00 \%$ & $0.00 \%$ & $0.00 \%$ & $0.00 \%$ & $0.65 \%$ \\
\hline female & $100.00 \%$ & & & & & $100.00 \%$ \\
\hline
\end{tabular}




\begin{tabular}{|c|c|c|c|c|c|c|}
\hline MFI - Rafiki & $2.78 \%$ & $0.00 \%$ & $0.00 \%$ & $0.00 \%$ & $0.00 \%$ & $0.65 \%$ \\
\hline female & $100.00 \%$ & & & & & $100.00 \%$ \\
\hline NBM & $5.56 \%$ & $0.00 \%$ & $0.00 \%$ & $0.00 \%$ & $0.00 \%$ & $1.30 \%$ \\
\hline male & $100.00 \%$ & & & & & $100.00 \%$ \\
\hline No & $52.78 \%$ & $0.00 \%$ & $13.33 \%$ & $73.33 \%$ & $66.67 \%$ & $49.35 \%$ \\
\hline female & $52.63 \%$ & & $50.00 \%$ & $36.36 \%$ & $45.45 \%$ & $46.05 \%$ \\
\hline male & $47.37 \%$ & & $50.00 \%$ & $63.64 \%$ & $54.55 \%$ & $53.95 \%$ \\
\hline Oriental Bank of Commerce & $0.00 \%$ & $9.09 \%$ & $0.00 \%$ & $0.00 \%$ & $0.00 \%$ & $1.30 \%$ \\
\hline male & & $100.00 \%$ & & & & $100.00 \%$ \\
\hline PAMECAS & $0.00 \%$ & $0.00 \%$ & $0.00 \%$ & $0.00 \%$ & $1.52 \%$ & $0.65 \%$ \\
\hline male & & & & & $100.00 \%$ & $100.00 \%$ \\
\hline Punjab National Bank & $0.00 \%$ & $27.27 \%$ & $0.00 \%$ & $0.00 \%$ & $0.00 \%$ & $3.90 \%$ \\
\hline male & & $100.00 \%$ & & & & $100.00 \%$ \\
\hline Rural Bank & $0.00 \%$ & $0.00 \%$ & $0.00 \%$ & $0.00 \%$ & $12.12 \%$ & $5.19 \%$ \\
\hline female & & & & & $25.00 \%$ & $25.00 \%$ \\
\hline male & & & & & $75.00 \%$ & $75.00 \%$ \\
\hline State Bank of India & $0.00 \%$ & $22.73 \%$ & $0.00 \%$ & $0.00 \%$ & $0.00 \%$ & $3.25 \%$ \\
\hline female & & $40.00 \%$ & & & & $40.00 \%$ \\
\hline male & & $60.00 \%$ & & & & $60.00 \%$ \\
\hline Syndicate bank & $0.00 \%$ & $4.55 \%$ & $0.00 \%$ & $0.00 \%$ & $0.00 \%$ & $0.65 \%$ \\
\hline female & & $100.00 \%$ & & & & $100.00 \%$ \\
\hline Union Bank of India & $0.00 \%$ & $4.55 \%$ & $0.00 \%$ & $0.00 \%$ & $0.00 \%$ & $0.65 \%$ \\
\hline male & & $100.00 \%$ & & & & $100.00 \%$ \\
\hline AD Bank & $0.00 \%$ & $0.00 \%$ & $0.00 \%$ & $0.00 \%$ & $3.03 \%$ & $1.30 \%$ \\
\hline female & & & & & $100.00 \%$ & $100.00 \%$ \\
\hline Grand Total & $100.00 \%$ & $100.00 \%$ & $100.00 \%$ & $100.00 \%$ & $100.00 \%$ & $100.00 \%$ \\
\hline
\end{tabular}

Table A2.6: Benefits of having a bank account, disaggregated by gender

\begin{tabular}{|c|c|c|c|c|c|c|}
\hline Benefits & East Africa & India & $\begin{array}{l}\text { L } \\
\text { America }\end{array}$ & SE Asia & $\begin{array}{l}\text { West } \\
\text { Africa }\end{array}$ & Grand Total \\
\hline Ability to do more business & $3.33 \%$ & $10.53 \%$ & $0.00 \%$ & $5.56 \%$ & $2.46 \%$ & $3.92 \%$ \\
\hline female & $50.00 \%$ & $0.00 \%$ & & $0.00 \%$ & $33.33 \%$ & $20.00 \%$ \\
\hline male & $50.00 \%$ & $100.00 \%$ & & $100.00 \%$ & $66.67 \%$ & $80.00 \%$ \\
\hline Ability to get a loan & $16.67 \%$ & $28.95 \%$ & $5.88 \%$ & $0.00 \%$ & $17.21 \%$ & $16.86 \%$ \\
\hline female & $50.00 \%$ & $9.09 \%$ & $100.00 \%$ & & $33.33 \%$ & $32.56 \%$ \\
\hline male & $50.00 \%$ & $90.91 \%$ & $0.00 \%$ & & $66.67 \%$ & $67.44 \%$ \\
\hline Ability to save money & $20.00 \%$ & $18.42 \%$ & $5.88 \%$ & $0.00 \%$ & $22.13 \%$ & $18.43 \%$ \\
\hline female & $50.00 \%$ & $14.29 \%$ & $100.00 \%$ & & $33.33 \%$ & $36.17 \%$ \\
\hline male & $50.00 \%$ & $85.71 \%$ & $0.00 \%$ & & $66.67 \%$ & $63.83 \%$ \\
\hline Ability to send or receive money & $5.00 \%$ & $21.05 \%$ & $5.88 \%$ & $11.11 \%$ & $4.92 \%$ & $7.84 \%$ \\
\hline female & $66.67 \%$ & $12.50 \%$ & $100.00 \%$ & $50.00 \%$ & $33.33 \%$ & $35.00 \%$ \\
\hline male & $33.33 \%$ & $87.50 \%$ & $0.00 \%$ & $50.00 \%$ & $66.67 \%$ & $65.00 \%$ \\
\hline $\begin{array}{l}\text { Ability to send or receive } \\
\text { payments }\end{array}$ & $0.00 \%$ & $10.53 \%$ & $64.71 \%$ & $0.00 \%$ & $6.56 \%$ & $9.02 \%$ \\
\hline female & & $0.00 \%$ & $90.91 \%$ & & $62.50 \%$ & $65.22 \%$ \\
\hline male & & $100.00 \%$ & $9.09 \%$ & & $37.50 \%$ & $34.78 \%$ \\
\hline $\begin{array}{l}\text { Avoid lengthy wait times for } \\
\text { getting paid }\end{array}$ & $1.67 \%$ & $2.63 \%$ & $0.00 \%$ & $5.56 \%$ & $0.00 \%$ & $1.18 \%$ \\
\hline female & $100.00 \%$ & $0.00 \%$ & & $0.00 \%$ & & $33.33 \%$ \\
\hline male & $0.00 \%$ & $100.00 \%$ & & $100.00 \%$ & & $66.67 \%$ \\
\hline Don't have & $0.00 \%$ & $0.00 \%$ & $0.00 \%$ & $0.00 \%$ & $0.82 \%$ & $0.39 \%$ \\
\hline female & & & & & $100.00 \%$ & $100.00 \%$ \\
\hline Don't know & $10.00 \%$ & $2.63 \%$ & $0.00 \%$ & $0.00 \%$ & $6.56 \%$ & $5.88 \%$ \\
\hline
\end{tabular}




\begin{tabular}{lllllll}
\hline female & $16.67 \%$ & $100.00 \%$ & & & $25.00 \%$ & $26.67 \%$ \\
male & $83.33 \%$ & $0.00 \%$ & & & $75.00 \%$ & $73.33 \%$ \\
Saving money in a secure location & $\mathbf{2 0 . 0 0 \%}$ & $\mathbf{2 . 6 3 \%}$ & $\mathbf{5 . 8 8 \%}$ & $\mathbf{5 . 5 6 \%}$ & $\mathbf{1 7 . 2 1 \%}$ & $\mathbf{1 4 . 1 2 \%}$ \\
\hline female & $58.33 \%$ & $0.00 \%$ & $100.00 \%$ & $0.00 \%$ & $\mathbf{2 3 . 8 1 \%}$ & $36.11 \%$ \\
$\quad$ male & $41.67 \%$ & $100.00 \%$ & $0.00 \%$ & $100.00 \%$ & $\mathbf{7 6 . 1 9 \%}$ & $63.89 \%$ \\
Other & $\mathbf{3 . 3 3 \%}$ & $\mathbf{2 . 6 3 \%}$ & $\mathbf{0 . 0 0 \%}$ & $\mathbf{7 2 . 2 2 \%}$ & $\mathbf{1 . 6 4 \%}$ & $\mathbf{7 . 0 6 \%}$ \\
\hline female & $100.00 \%$ & $0.00 \%$ & & $30.77 \%$ & $50.00 \%$ & $38.89 \%$ \\
$\quad$ male & $0.00 \%$ & $100.00 \%$ & & $69.23 \%$ & $50.00 \%$ & $61.11 \%$ \\
not applicable & $\mathbf{2 0 . 0 0 \%}$ & $\mathbf{0 . 0 0 \%}$ & $\mathbf{1 1 . 7 6 \%}$ & $\mathbf{0 . 0 0 \%}$ & $\mathbf{2 0 . 4 9 \%}$ & $\mathbf{1 5 . 2 9 \%}$ \\
$\quad$ female & $66.67 \%$ & & $50.00 \%$ & & $56.00 \%$ & $58.97 \%$ \\
$\quad$ male & $33.33 \%$ & & $50.00 \%$ & & $\mathbf{4 4 . 0 0 \%}$ & $\mathbf{4 1 . 0 3 \%}$ \\
\hline Grand Total & $\mathbf{1 0 0 . 0 0 \%}$ & $\mathbf{1 0 0 . 0 0 \%}$ & $\mathbf{1 0 0 . 0 0 \%}$ & $\mathbf{1 0 0 . 0 0 \%}$ & $\mathbf{1 0 0 . 0 0 \%}$ & $\mathbf{1 0 0 . 0 0 \%}$ \\
\hline
\end{tabular}

Table A2.7: Formal financial institutions (others than banks) that provided financial services and products last year, disaggregated by gender

\begin{tabular}{|c|c|c|c|c|c|c|}
\hline Formal financial institution & East Africa & India & L America & SE Asia & West Africa & Grand Total \\
\hline Cooperative & $5.00 \%$ & $56.00 \%$ & $12.50 \%$ & $0.00 \%$ & $22.50 \%$ & $19.89 \%$ \\
\hline female & $50.00 \%$ & $21.43 \%$ & $100.00 \%$ & & $22.22 \%$ & $27.78 \%$ \\
\hline male & $50.00 \%$ & $78.57 \%$ & $0.00 \%$ & & $77.78 \%$ & $72.22 \%$ \\
\hline Microfinance institution & $22.50 \%$ & $4.00 \%$ & $25.00 \%$ & $40.00 \%$ & $25.00 \%$ & $23.20 \%$ \\
\hline female & $88.89 \%$ & $0.00 \%$ & $75.00 \%$ & $37.50 \%$ & $30.00 \%$ & $47.62 \%$ \\
\hline male & $11.11 \%$ & $100.00 \%$ & $25.00 \%$ & $62.50 \%$ & $70.00 \%$ & $52.38 \%$ \\
\hline Post office & $5.00 \%$ & $24.00 \%$ & $18.75 \%$ & $0.00 \%$ & $2.50 \%$ & $7.18 \%$ \\
\hline female & $100.00 \%$ & $0.00 \%$ & $66.67 \%$ & & $50.00 \%$ & $38.46 \%$ \\
\hline male & $0.00 \%$ & $100.00 \%$ & $33.33 \%$ & & $50.00 \%$ & $61.54 \%$ \\
\hline SACCO & $20.00 \%$ & $0.00 \%$ & $0.00 \%$ & $25.00 \%$ & $6.25 \%$ & $9.94 \%$ \\
\hline female & $25.00 \%$ & & & $20.00 \%$ & $20.00 \%$ & $22.22 \%$ \\
\hline male & $75.00 \%$ & & & $80.00 \%$ & $80.00 \%$ & $77.78 \%$ \\
\hline Other & $2.50 \%$ & $4.00 \%$ & $0.00 \%$ & $20.00 \%$ & $7.50 \%$ & $6.63 \%$ \\
\hline female & $100.00 \%$ & $100.00 \%$ & & $25.00 \%$ & $50.00 \%$ & $50.00 \%$ \\
\hline male & $0.00 \%$ & $0.00 \%$ & & $75.00 \%$ & $50.00 \%$ & $50.00 \%$ \\
\hline Not applicable & $45.00 \%$ & $12.00 \%$ & $43.75 \%$ & $15.00 \%$ & $36.25 \%$ & $33.15 \%$ \\
\hline female & $55.56 \%$ & $0.00 \%$ & $100.00 \%$ & $33.33 \%$ & $62.07 \%$ & $60.00 \%$ \\
\hline male & $44.44 \%$ & $100.00 \%$ & $0.00 \%$ & $66.67 \%$ & $37.93 \%$ & $40.00 \%$ \\
\hline Grand Total & $100.00 \%$ & $100.00 \%$ & $100.00 \%$ & $100.00 \%$ & $100.00 \%$ & $100.00 \%$ \\
\hline
\end{tabular}


Table A2.8: Informal financial institutions providing financial services and products, disaggregated by gender

\begin{tabular}{|c|c|c|c|c|c|c|}
\hline Informal financial institution & East Africa & India & $\begin{array}{l}\text { L } \\
\text { America }\end{array}$ & SE Asia & $\begin{array}{l}\text { West } \\
\text { Africa }\end{array}$ & $\begin{array}{l}\text { Grand } \\
\text { Total }\end{array}$ \\
\hline A money guard & $0.00 \%$ & $0.00 \%$ & $0.00 \%$ & $19.05 \%$ & $7.07 \%$ & $4.95 \%$ \\
\hline female & & & & $50.00 \%$ & $28.57 \%$ & $36.36 \%$ \\
\hline male & & & & $50.00 \%$ & $71.43 \%$ & $63.64 \%$ \\
\hline Input supplier (e.g. goods on credit) & $6.56 \%$ & $29.63 \%$ & $7.14 \%$ & $0.00 \%$ & $6.06 \%$ & $8.56 \%$ \\
\hline female & $100.00 \%$ & $0.00 \%$ & $100.00 \%$ & & $50.00 \%$ & $42.11 \%$ \\
\hline male & $0.00 \%$ & $100.00 \%$ & $0.00 \%$ & & $50.00 \%$ & $57.89 \%$ \\
\hline $\begin{array}{l}\text { Merry-go-round/informal saving } \\
\text { network }\end{array}$ & $36.07 \%$ & $0.00 \%$ & $42.86 \%$ & $71.43 \%$ & $23.23 \%$ & $29.73 \%$ \\
\hline female & $59.09 \%$ & & $100.00 \%$ & $33.33 \%$ & $65.22 \%$ & $59.09 \%$ \\
\hline male & $40.91 \%$ & & $0.00 \%$ & $66.67 \%$ & $34.78 \%$ & $40.91 \%$ \\
\hline Other groups & $3.28 \%$ & $3.70 \%$ & $0.00 \%$ & $0.00 \%$ & $5.05 \%$ & $3.60 \%$ \\
\hline female & $100.00 \%$ & $0.00 \%$ & & & $40.00 \%$ & $50.00 \%$ \\
\hline male & $0.00 \%$ & $100.00 \%$ & & & $60.00 \%$ & $50.00 \%$ \\
\hline Processing industry & $0.00 \%$ & $0.00 \%$ & $0.00 \%$ & $0.00 \%$ & $4.04 \%$ & $1.80 \%$ \\
\hline female & & & & & $50.00 \%$ & $50.00 \%$ \\
\hline male & & & & & $50.00 \%$ & $50.00 \%$ \\
\hline Remittances funds & $8.20 \%$ & $0.00 \%$ & $0.00 \%$ & $0.00 \%$ & $7.07 \%$ & $5.41 \%$ \\
\hline female & $60.00 \%$ & & & & $85.71 \%$ & $75.00 \%$ \\
\hline male & $40.00 \%$ & & & & $14.29 \%$ & $25.00 \%$ \\
\hline $\begin{array}{l}\text { Savings collectors (not closely } \\
\text { related to the family) }\end{array}$ & $4.92 \%$ & $0.00 \%$ & $0.00 \%$ & $9.52 \%$ & $7.07 \%$ & $5.41 \%$ \\
\hline female & $66.67 \%$ & & & $50.00 \%$ & $85.71 \%$ & $75.00 \%$ \\
\hline male & $33.33 \%$ & & & $50.00 \%$ & $14.29 \%$ & $25.00 \%$ \\
\hline Shop keepers & $18.03 \%$ & $14.81 \%$ & $21.43 \%$ & $0.00 \%$ & $12.12 \%$ & $13.51 \%$ \\
\hline female & $63.64 \%$ & $0.00 \%$ & $66.67 \%$ & & $16.67 \%$ & $36.67 \%$ \\
\hline male & $36.36 \%$ & $100.00 \%$ & $33.33 \%$ & & $83.33 \%$ & $63.33 \%$ \\
\hline Trader & $16.39 \%$ & $48.15 \%$ & $0.00 \%$ & $0.00 \%$ & $4.04 \%$ & $12.16 \%$ \\
\hline female & $50.00 \%$ & $23.08 \%$ & & & $75.00 \%$ & $40.74 \%$ \\
\hline male & $50.00 \%$ & $76.92 \%$ & & & $25.00 \%$ & $59.26 \%$ \\
\hline Vouchers & $4.92 \%$ & $0.00 \%$ & $0.00 \%$ & $0.00 \%$ & $0.00 \%$ & $1.35 \%$ \\
\hline female & $33.33 \%$ & & & & & $33.33 \%$ \\
\hline male & $66.67 \%$ & & & & & $66.67 \%$ \\
\hline not applicable & $1.64 \%$ & $3.70 \%$ & $28.57 \%$ & $0.00 \%$ & $24.24 \%$ & $13.51 \%$ \\
\hline female & $100.00 \%$ & $100.00 \%$ & $75.00 \%$ & & $33.33 \%$ & $43.33 \%$ \\
\hline male & $0.00 \%$ & $0.00 \%$ & $25.00 \%$ & & $66.67 \%$ & $56.67 \%$ \\
\hline Grand Total & $100.00 \%$ & $100.00 \%$ & $100.00 \%$ & $100.00 \%$ & $100.00 \%$ & $100.00 \%$ \\
\hline
\end{tabular}


Table A2.9: Percentage of respondents who received credit/a loan last year, differentiated by gender

\begin{tabular}{|c|c|}
\hline & Count of used credit \\
\hline no & $35.81 \%$ \\
\hline female & $35.85 \%$ \\
\hline East Africa & $26.32 \%$ \\
\hline India & $5.26 \%$ \\
\hline L America & $21.05 \%$ \\
\hline West Africa & $47.37 \%$ \\
\hline male & $64.15 \%$ \\
\hline East Africa & $23.53 \%$ \\
\hline India & $8.82 \%$ \\
\hline L America & $2.94 \%$ \\
\hline SE Asia & $2.94 \%$ \\
\hline West Africa & $61.76 \%$ \\
\hline yes & $64.19 \%$ \\
\hline female & $51.58 \%$ \\
\hline East Africa & $28.57 \%$ \\
\hline India & $6.12 \%$ \\
\hline L America & $16.33 \%$ \\
\hline SE Asia & $10.20 \%$ \\
\hline West Africa & $38.78 \%$ \\
\hline male & $48.42 \%$ \\
\hline East Africa & $17.39 \%$ \\
\hline India & $23.91 \%$ \\
\hline L America & $2.17 \%$ \\
\hline SE Asia & $19.57 \%$ \\
\hline West Africa & $36.96 \%$ \\
\hline Grand Total & $100.00 \%$ \\
\hline
\end{tabular}

Table A2.10: Financial institutions that provided loan/credit last year, disaggregated by gender

\begin{tabular}{|c|c|c|c|c|c|c|}
\hline Financial institution & East Africa & India & L America & SE Asia & West Africa & Grand Total \\
\hline Bank & $5.26 \%$ & $34.62 \%$ & $42.86 \%$ & $47.06 \%$ & $2.78 \%$ & $16.17 \%$ \\
\hline female & $50.00 \%$ & $0.00 \%$ & $100.00 \%$ & $25.00 \%$ & $50.00 \%$ & $37.04 \%$ \\
\hline male & $50.00 \%$ & $100.00 \%$ & $0.00 \%$ & $75.00 \%$ & $50.00 \%$ & $62.96 \%$ \\
\hline Cooperative & $2.63 \%$ & $0.00 \%$ & $7.14 \%$ & $0.00 \%$ & $1.39 \%$ & $1.80 \%$ \\
\hline female & $100.00 \%$ & & $100.00 \%$ & & $0.00 \%$ & $66.67 \%$ \\
\hline male & $0.00 \%$ & & $0.00 \%$ & & $100.00 \%$ & $33.33 \%$ \\
\hline Family & $0.00 \%$ & $3.85 \%$ & $7.14 \%$ & $5.88 \%$ & $4.17 \%$ & $3.59 \%$ \\
\hline female & & $0.00 \%$ & $0.00 \%$ & $100.00 \%$ & $0.00 \%$ & $16.67 \%$ \\
\hline male & & $100.00 \%$ & $100.00 \%$ & $0.00 \%$ & $100.00 \%$ & $83.33 \%$ \\
\hline Friend & $2.63 \%$ & $3.85 \%$ & $7.14 \%$ & $5.88 \%$ & $5.56 \%$ & $4.79 \%$ \\
\hline female & $100.00 \%$ & $100.00 \%$ & $100.00 \%$ & $0.00 \%$ & $75.00 \%$ & $75.00 \%$ \\
\hline male & $0.00 \%$ & $0.00 \%$ & $0.00 \%$ & $100.00 \%$ & $25.00 \%$ & $25.00 \%$ \\
\hline MFI & $7.89 \%$ & $0.00 \%$ & $0.00 \%$ & $0.00 \%$ & $9.72 \%$ & $5.99 \%$ \\
\hline female & $66.67 \%$ & & & & $14.29 \%$ & $30.00 \%$ \\
\hline male & $33.33 \%$ & & & & $85.71 \%$ & $70.00 \%$ \\
\hline Moneylender & $0.00 \%$ & $3.85 \%$ & $0.00 \%$ & $0.00 \%$ & $2.78 \%$ & $1.80 \%$ \\
\hline
\end{tabular}




\begin{tabular}{|c|c|c|c|c|c|c|}
\hline female & & $0.00 \%$ & & & $100.00 \%$ & $66.67 \%$ \\
\hline male & & $100.00 \%$ & & & $0.00 \%$ & $33.33 \%$ \\
\hline Others & $7.89 \%$ & $0.00 \%$ & $0.00 \%$ & $17.65 \%$ & $6.94 \%$ & $6.59 \%$ \\
\hline female & $33.33 \%$ & & & $66.67 \%$ & $40.00 \%$ & $45.45 \%$ \\
\hline male & $66.67 \%$ & & & $33.33 \%$ & $60.00 \%$ & $54.55 \%$ \\
\hline SACCO & $13.16 \%$ & $0.00 \%$ & $0.00 \%$ & $5.88 \%$ & $0.00 \%$ & $3.59 \%$ \\
\hline female & $20.00 \%$ & & & $100.00 \%$ & & $33.33 \%$ \\
\hline male & $80.00 \%$ & & & $0.00 \%$ & & $66.67 \%$ \\
\hline Trader & $0.00 \%$ & $38.46 \%$ & $0.00 \%$ & $0.00 \%$ & $0.00 \%$ & $5.99 \%$ \\
\hline female & & $30.00 \%$ & & & & $30.00 \%$ \\
\hline male & & $70.00 \%$ & & & & $70.00 \%$ \\
\hline VSLA & $21.05 \%$ & $0.00 \%$ & $0.00 \%$ & $5.88 \%$ & $30.56 \%$ & $18.56 \%$ \\
\hline female & $87.50 \%$ & & & $0.00 \%$ & $68.18 \%$ & $70.97 \%$ \\
\hline male & $12.50 \%$ & & & $100.00 \%$ & $31.82 \%$ & $29.03 \%$ \\
\hline Not applicable & $39.47 \%$ & $15.38 \%$ & $35.71 \%$ & $11.76 \%$ & $36.11 \%$ & $31.14 \%$ \\
\hline female & $46.67 \%$ & $25.00 \%$ & $80.00 \%$ & $0.00 \%$ & $30.77 \%$ & $38.46 \%$ \\
\hline male & $53.33 \%$ & $75.00 \%$ & $20.00 \%$ & $100.00 \%$ & $69.23 \%$ & $61.54 \%$ \\
\hline Grand Total & $100.00 \%$ & $100.00 \%$ & $100.00 \%$ & $100.00 \%$ & $100.00 \%$ & $100.00 \%$ \\
\hline
\end{tabular}

Table A2.11: Repayment modality

\begin{tabular}{lllllll} 
Repayment modality & East Africa & India & L America & SE Asia & West Africa & Grand Total \\
\hline After harvesting & $2.86 \%$ & $72.22 \%$ & $0.00 \%$ & $6.67 \%$ & $15.15 \%$ & $16.89 \%$ \\
Every 3 months & $5.71 \%$ & $0.00 \%$ & $0.00 \%$ & $0.00 \%$ & $12.12 \%$ & $6.76 \%$ \\
Every month & $54.29 \%$ & $0.00 \%$ & $14.29 \%$ & $86.67 \%$ & $16.67 \%$ & $30.41 \%$ \\
Every year & $5.71 \%$ & $0.00 \%$ & $50.00 \%$ & $0.00 \%$ & $3.03 \%$ & $7.43 \%$ \\
Other & $2.86 \%$ & $0.00 \%$ & $7.14 \%$ & $0.00 \%$ & $3.03 \%$ & $2.70 \%$ \\
Not applicable & $28.57 \%$ & $27.78 \%$ & $28.57 \%$ & $6.67 \%$ & $50.00 \%$ & $35.81 \%$ \\
\hline Grand Total & $\mathbf{1 0 0 . 0 0 \%}$ & $\mathbf{1 0 0 . 0 0 \%}$ & $\mathbf{1 0 0 . 0 0 \%}$ & $\mathbf{1 0 0 . 0 0 \%}$ & $\mathbf{1 0 0 . 0 0 \%}$ & $\mathbf{1 0 0 . 0 0 \%}$
\end{tabular}

Table A2.12: Reasons for not asking credit from a bank

\begin{tabular}{|c|c|c|c|c|c|c|}
\hline Reasons & East Africa & India & $\begin{array}{l}\mathrm{L} \\
\text { America }\end{array}$ & SE Asia & $\begin{array}{l}\text { West } \\
\text { Africa }\end{array}$ & $\begin{array}{l}\text { Grand } \\
\text { Total }\end{array}$ \\
\hline Don't know procedures & $0.00 \%$ & $0.00 \%$ & $7.14 \%$ & $0.00 \%$ & $4.55 \%$ & $2.70 \%$ \\
\hline $\begin{array}{l}\text { Farming is very risky and banks have no } \\
\text { confidence to farmers }\end{array}$ & $0.00 \%$ & $0.00 \%$ & $7.14 \%$ & $0.00 \%$ & $16.67 \%$ & $8.11 \%$ \\
\hline Interest rate too high & $0.00 \%$ & $0.00 \%$ & $7.14 \%$ & $0.00 \%$ & $3.03 \%$ & $2.03 \%$ \\
\hline Other & $0.00 \%$ & $0.00 \%$ & $0.00 \%$ & $0.00 \%$ & $4.55 \%$ & $2.03 \%$ \\
\hline Procedures complicated & $0.00 \%$ & $0.00 \%$ & $0.00 \%$ & $0.00 \%$ & $6.06 \%$ & $2.70 \%$ \\
\hline Not applicable & $100.00 \%$ & $100.00 \%$ & $78.57 \%$ & $100.00 \%$ & $65.15 \%$ & $82.43 \%$ \\
\hline Grand Total & $100.00 \%$ & $100.00 \%$ & $100.00 \%$ & $100.00 \%$ & $100.00 \%$ & $100.00 \%$ \\
\hline
\end{tabular}




\section{Annex 3 Survey results (part 2-Climate Smart Agriculture and Investments)}

Soil conservation or land preparation technologies or practices

Table A3.1: Soil conservation or land preparation technologies or practices applied, disaggregated by gender

\begin{tabular}{|c|c|c|c|c|c|c|}
\hline Technologies/practices & East Africa & India & L America & SE Asia & West Africa & Grand Total \\
\hline Crop and pasture rotation & $0.00 \%$ & $10.71 \%$ & $4.08 \%$ & $0.00 \%$ & $2.78 \%$ & $3.87 \%$ \\
\hline female & & $0.00 \%$ & $50.00 \%$ & & $66.67 \%$ & $27.27 \%$ \\
\hline male & & $100.00 \%$ & $50.00 \%$ & & $33.33 \%$ & $72.73 \%$ \\
\hline Fire & $0.00 \%$ & $0.00 \%$ & $0.00 \%$ & $0.00 \%$ & $10.19 \%$ & $3.87 \%$ \\
\hline female & & & & & $18.18 \%$ & $18.18 \%$ \\
\hline male & & & & & $81.82 \%$ & $81.82 \%$ \\
\hline Ground cover & $0.00 \%$ & $0.00 \%$ & $8.16 \%$ & $0.00 \%$ & $0.00 \%$ & $1.41 \%$ \\
\hline female & & & $100.00 \%$ & & & $100.00 \%$ \\
\hline Intercropping & $1.79 \%$ & $0.00 \%$ & $2.04 \%$ & $0.00 \%$ & $4.63 \%$ & $2.46 \%$ \\
\hline female & $100.00 \%$ & & $100.00 \%$ & & $40.00 \%$ & $57.14 \%$ \\
\hline male & $0.00 \%$ & & $0.00 \%$ & & $60.00 \%$ & $42.86 \%$ \\
\hline Laser Land Leveller & $0.00 \%$ & $32.14 \%$ & $0.00 \%$ & $0.00 \%$ & $0.00 \%$ & $6.34 \%$ \\
\hline female & & $22.22 \%$ & & & & $22.22 \%$ \\
\hline male & & $77.78 \%$ & & & & $77.78 \%$ \\
\hline Nutrient management & $26.79 \%$ & $5.36 \%$ & $28.57 \%$ & $0.00 \%$ & $7.41 \%$ & $14.08 \%$ \\
\hline female & $46.67 \%$ & $0.00 \%$ & $85.71 \%$ & & $37.50 \%$ & $55.00 \%$ \\
\hline male & $53.33 \%$ & $100.00 \%$ & $14.29 \%$ & & $62.50 \%$ & $45.00 \%$ \\
\hline Other & $17.86 \%$ & $12.50 \%$ & $4.08 \%$ & $0.00 \%$ & $10.19 \%$ & $10.56 \%$ \\
\hline female & $30.00 \%$ & $0.00 \%$ & $100.00 \%$ & & $27.27 \%$ & $26.67 \%$ \\
\hline male & $70.00 \%$ & $100.00 \%$ & $0.00 \%$ & & $72.73 \%$ & $73.33 \%$ \\
\hline Ploughing & $7.14 \%$ & $1.79 \%$ & $26.53 \%$ & $0.00 \%$ & $1.85 \%$ & $7.04 \%$ \\
\hline female & $100.00 \%$ & $0.00 \%$ & $84.62 \%$ & & $0.00 \%$ & $75.00 \%$ \\
\hline male & $0.00 \%$ & $100.00 \%$ & $15.38 \%$ & & $100.00 \%$ & $25.00 \%$ \\
\hline RNA & $0.00 \%$ & $0.00 \%$ & $0.00 \%$ & $0.00 \%$ & $21.30 \%$ & $8.10 \%$ \\
\hline female & & & & & $43.48 \%$ & $43.48 \%$ \\
\hline male & & & & & $56.52 \%$ & $56.52 \%$ \\
\hline Scraping before sowing & $0.00 \%$ & $0.00 \%$ & $0.00 \%$ & $0.00 \%$ & $7.41 \%$ & $2.82 \%$ \\
\hline male & & & & & $100.00 \%$ & $100.00 \%$ \\
\hline Turbo Happy Seeder & $0.00 \%$ & $26.79 \%$ & $0.00 \%$ & $0.00 \%$ & $0.00 \%$ & $5.28 \%$ \\
\hline female & & $20.00 \%$ & & & & $20.00 \%$ \\
\hline male & & $80.00 \%$ & & & & $80.00 \%$ \\
\hline Water management & $42.86 \%$ & $1.79 \%$ & $0.00 \%$ & $0.00 \%$ & $28.70 \%$ & $19.72 \%$ \\
\hline female & $54.17 \%$ & $0.00 \%$ & & & $51.61 \%$ & $51.79 \%$ \\
\hline male & $45.83 \%$ & $100.00 \%$ & & & $48.39 \%$ & $48.21 \%$ \\
\hline Zero/minimum tillage & $0.00 \%$ & $8.93 \%$ & $26.53 \%$ & $0.00 \%$ & $5.56 \%$ & $8.45 \%$ \\
\hline female & & $20.00 \%$ & $84.62 \%$ & & $50.00 \%$ & $62.50 \%$ \\
\hline male & & $80.00 \%$ & $15.38 \%$ & & $50.00 \%$ & $37.50 \%$ \\
\hline Not applicable & $3.57 \%$ & $0.00 \%$ & $0.00 \%$ & $100.00 \%$ & $0.00 \%$ & $5.99 \%$ \\
\hline
\end{tabular}




\begin{tabular}{|c|c|c|c|c|c|c|}
\hline female & $100.00 \%$ & & & $33.33 \%$ & & $41.18 \%$ \\
\hline male & $0.00 \%$ & & & $66.67 \%$ & & $58.82 \%$ \\
\hline Grand Total & $100.00 \%$ & $100.00 \%$ & $100.00 \%$ & $100.00 \%$ & $100.00 \%$ & $100.00 \%$ \\
\hline
\end{tabular}

Table A3.2 : Amount of investment in soil conservation or land preparation technologies or practices applied, disaggregated by gender

\begin{tabular}{|c|c|c|c|c|c|c|}
\hline Amount (\$) & East Africa & India & L America & SE Asia & West Africa & Grand Total \\
\hline 0 & $0.00 \%$ & $5.56 \%$ & $0.00 \%$ & $0.00 \%$ & $38.46 \%$ & $17.69 \%$ \\
\hline female & & $0.00 \%$ & & & $36.00 \%$ & $34.62 \%$ \\
\hline male & & $100.00 \%$ & & & $64.00 \%$ & $65.38 \%$ \\
\hline $0-50$ & $62.86 \%$ & $0.00 \%$ & $21.43 \%$ & $0.00 \%$ & $36.92 \%$ & $33.33 \%$ \\
\hline female & $54.55 \%$ & & $100.00 \%$ & & $45.83 \%$ & $53.06 \%$ \\
\hline male & $45.45 \%$ & & $0.00 \%$ & & $54.17 \%$ & $46.94 \%$ \\
\hline $50-100$ & $0.00 \%$ & $0.00 \%$ & $7.14 \%$ & $0.00 \%$ & $6.15 \%$ & $3.40 \%$ \\
\hline female & & & $100.00 \%$ & & $50.00 \%$ & $60.00 \%$ \\
\hline male & & & $0.00 \%$ & & $50.00 \%$ & $40.00 \%$ \\
\hline $100-500$ & $8.57 \%$ & $27.78 \%$ & $42.86 \%$ & $0.00 \%$ & $3.08 \%$ & $10.88 \%$ \\
\hline female & $33.33 \%$ & $60.00 \%$ & $83.33 \%$ & & $50.00 \%$ & $62.50 \%$ \\
\hline male & $66.67 \%$ & $40.00 \%$ & $16.67 \%$ & & $50.00 \%$ & $37.50 \%$ \\
\hline $500-1000$ & $0.00 \%$ & $5.56 \%$ & $28.57 \%$ & $0.00 \%$ & $0.00 \%$ & $3.40 \%$ \\
\hline female & & $0.00 \%$ & $75.00 \%$ & & & $60.00 \%$ \\
\hline male & & $100.00 \%$ & $25.00 \%$ & & & $40.00 \%$ \\
\hline$>1000$ & $0.00 \%$ & $27.78 \%$ & $0.00 \%$ & $0.00 \%$ & $0.00 \%$ & $3.40 \%$ \\
\hline female & & $20.00 \%$ & & & & $20.00 \%$ \\
\hline male & & $80.00 \%$ & & & & $80.00 \%$ \\
\hline Not Applicable & $28.57 \%$ & $33.33 \%$ & $0.00 \%$ & $100.00 \%$ & $15.38 \%$ & $27.89 \%$ \\
\hline female & $60.00 \%$ & $0.00 \%$ & & $33.33 \%$ & $50.00 \%$ & $39.02 \%$ \\
\hline male & $40.00 \%$ & $100.00 \%$ & & $66.67 \%$ & $50.00 \%$ & $60.98 \%$ \\
\hline (blank) & $0.00 \%$ & $0.00 \%$ & $0.00 \%$ & $0.00 \%$ & $0.00 \%$ & $0.00 \%$ \\
\hline \multicolumn{7}{|l|}{ male } \\
\hline Grand Total & $100.00 \%$ & $100.00 \%$ & $100.00 \%$ & $100.00 \%$ & $100.00 \%$ & $100.00 \%$ \\
\hline
\end{tabular}


Table A3.3: Financial institutions that provided financial products or services for soil conservation or land preparation technologies or practices applied, disaggregated by gender

\begin{tabular}{|c|c|c|c|c|c|c|}
\hline Financial institute & East Africa & India & $\begin{array}{l}\mathrm{L} \\
\text { America }\end{array}$ & SE Asia & $\begin{array}{l}\text { West } \\
\text { Africa }\end{array}$ & $\begin{array}{l}\text { Grand } \\
\text { Total }\end{array}$ \\
\hline bank & $0.00 \%$ & $11.11 \%$ & $0.00 \%$ & $0.00 \%$ & $0.00 \%$ & $1.23 \%$ \\
\hline male & & $100.00 \%$ & & & & $100.00 \%$ \\
\hline Cooperative & $5.00 \%$ & $0.00 \%$ & $0.00 \%$ & $0.00 \%$ & $1.37 \%$ & $1.84 \%$ \\
\hline female & $50.00 \%$ & & & & $0.00 \%$ & $33.33 \%$ \\
\hline male & $50.00 \%$ & & & & $100.00 \%$ & $66.67 \%$ \\
\hline Other & $0.00 \%$ & $0.00 \%$ & $17.65 \%$ & $0.00 \%$ & $6.85 \%$ & $4.91 \%$ \\
\hline female & & & $100.00 \%$ & & $60.00 \%$ & $75.00 \%$ \\
\hline male & & & $0.00 \%$ & & $40.00 \%$ & $25.00 \%$ \\
\hline Remittances funds & $17.50 \%$ & $0.00 \%$ & $0.00 \%$ & $0.00 \%$ & $2.74 \%$ & $5.52 \%$ \\
\hline female & $85.71 \%$ & & & & $100.00 \%$ & $88.89 \%$ \\
\hline male & $14.29 \%$ & & & & $0.00 \%$ & $11.11 \%$ \\
\hline SACCO & $10.00 \%$ & $0.00 \%$ & $0.00 \%$ & $0.00 \%$ & $1.37 \%$ & $3.07 \%$ \\
\hline female & $50.00 \%$ & & & & $100.00 \%$ & $60.00 \%$ \\
\hline male & $50.00 \%$ & & & & $0.00 \%$ & $40.00 \%$ \\
\hline sale of farm products & $0.00 \%$ & $0.00 \%$ & $76.47 \%$ & $0.00 \%$ & $4.11 \%$ & $9.82 \%$ \\
\hline female & & & $84.62 \%$ & & $66.67 \%$ & $81.25 \%$ \\
\hline male & & & $15.38 \%$ & & $33.33 \%$ & $18.75 \%$ \\
\hline Self-financed & $15.00 \%$ & $44.44 \%$ & $5.88 \%$ & $0.00 \%$ & $16.44 \%$ & $16.56 \%$ \\
\hline female & $50.00 \%$ & $25.00 \%$ & $100.00 \%$ & & $33.33 \%$ & $37.04 \%$ \\
\hline male & $50.00 \%$ & $75.00 \%$ & $0.00 \%$ & & $66.67 \%$ & $62.96 \%$ \\
\hline Trader & $5.00 \%$ & $5.56 \%$ & $0.00 \%$ & $0.00 \%$ & $5.48 \%$ & $4.29 \%$ \\
\hline female & $0.00 \%$ & $100.00 \%$ & & & $50.00 \%$ & $42.86 \%$ \\
\hline male & $100.00 \%$ & $0.00 \%$ & & & $50.00 \%$ & $57.14 \%$ \\
\hline VSLA & $0.00 \%$ & $0.00 \%$ & $0.00 \%$ & $0.00 \%$ & $6.85 \%$ & $3.07 \%$ \\
\hline female & & & & & $40.00 \%$ & $40.00 \%$ \\
\hline male & & & & & $60.00 \%$ & $60.00 \%$ \\
\hline Not Applicable & $12.50 \%$ & $38.89 \%$ & $0.00 \%$ & $100.00 \%$ & $49.32 \%$ & $38.65 \%$ \\
\hline female & $60.00 \%$ & $14.29 \%$ & & $33.33 \%$ & $38.89 \%$ & $36.51 \%$ \\
\hline male & $40.00 \%$ & $85.71 \%$ & & $66.67 \%$ & $61.11 \%$ & $63.49 \%$ \\
\hline Merry-go-round & $27.50 \%$ & $0.00 \%$ & $0.00 \%$ & $0.00 \%$ & $4.11 \%$ & $8.59 \%$ \\
\hline female & $54.55 \%$ & & & & $100.00 \%$ & $64.29 \%$ \\
\hline male & $45.45 \%$ & & & & $0.00 \%$ & $35.71 \%$ \\
\hline A money guard & $2.50 \%$ & $0.00 \%$ & $0.00 \%$ & $0.00 \%$ & $1.37 \%$ & $1.23 \%$ \\
\hline female & $0.00 \%$ & & & & $100.00 \%$ & $50.00 \%$ \\
\hline male & $100.00 \%$ & & & & $0.00 \%$ & $50.00 \%$ \\
\hline Input supplier & $2.50 \%$ & $0.00 \%$ & $0.00 \%$ & $0.00 \%$ & $0.00 \%$ & $0.61 \%$ \\
\hline female & $100.00 \%$ & & & & & $100.00 \%$ \\
\hline Savings collectors & $2.50 \%$ & $0.00 \%$ & $0.00 \%$ & $0.00 \%$ & $0.00 \%$ & $0.61 \%$ \\
\hline male & $100.00 \%$ & & & & & $100.00 \%$ \\
\hline Grand Total & $100.00 \%$ & $100.00 \%$ & $100.00 \%$ & $100.00 \%$ & $100.00 \%$ & $100.00 \%$ \\
\hline
\end{tabular}


Table A3.4: Risks in soil conservation or land preparation technologies or practices, disaggregated by gender

\begin{tabular}{|c|c|c|c|c|c|c|}
\hline Risks & East Africa & India & L America & SE Asia & West Africa & Grand Total \\
\hline Diseases & $2.63 \%$ & $0.00 \%$ & $42.86 \%$ & $0.00 \%$ & $0.00 \%$ & $4.38 \%$ \\
\hline female & $100.00 \%$ & & $83.33 \%$ & & & $85.71 \%$ \\
\hline male & $0.00 \%$ & & $16.67 \%$ & & & $14.29 \%$ \\
\hline Drought & $13.16 \%$ & $0.00 \%$ & $7.14 \%$ & $0.00 \%$ & $4.11 \%$ & $5.63 \%$ \\
\hline female & $40.00 \%$ & & $100.00 \%$ & & $33.33 \%$ & $44.44 \%$ \\
\hline male & $60.00 \%$ & & $0.00 \%$ & & $66.67 \%$ & $55.56 \%$ \\
\hline Erosion & $10.53 \%$ & $0.00 \%$ & $0.00 \%$ & $0.00 \%$ & $1.37 \%$ & $3.13 \%$ \\
\hline female & $50.00 \%$ & & & & $0.00 \%$ & $40.00 \%$ \\
\hline male & $50.00 \%$ & & & & $100.00 \%$ & $60.00 \%$ \\
\hline High costs & $28.95 \%$ & $5.00 \%$ & $0.00 \%$ & $0.00 \%$ & $16.44 \%$ & $15.00 \%$ \\
\hline female & $54.55 \%$ & $0.00 \%$ & & & $66.67 \%$ & $58.33 \%$ \\
\hline male & $45.45 \%$ & $100.00 \%$ & & & $33.33 \%$ & $41.67 \%$ \\
\hline Higher weeds & $0.00 \%$ & $5.00 \%$ & $0.00 \%$ & $0.00 \%$ & $1.37 \%$ & $1.25 \%$ \\
\hline male & & $100.00 \%$ & & & $100.00 \%$ & $100.00 \%$ \\
\hline Lower yield & $0.00 \%$ & $5.00 \%$ & $7.14 \%$ & $0.00 \%$ & $0.00 \%$ & $1.25 \%$ \\
\hline female & & $0.00 \%$ & $100.00 \%$ & & & $50.00 \%$ \\
\hline male & & $100.00 \%$ & $0.00 \%$ & & & $50.00 \%$ \\
\hline None & $2.63 \%$ & $85.00 \%$ & $35.71 \%$ & $0.00 \%$ & $38.36 \%$ & $31.88 \%$ \\
\hline female & $100.00 \%$ & $23.53 \%$ & $80.00 \%$ & & $39.29 \%$ & $39.22 \%$ \\
\hline male & $0.00 \%$ & $76.47 \%$ & $20.00 \%$ & & $60.71 \%$ & $60.78 \%$ \\
\hline Other & $31.58 \%$ & $0.00 \%$ & $7.14 \%$ & $0.00 \%$ & $12.33 \%$ & $13.75 \%$ \\
\hline female & $50.00 \%$ & & $100.00 \%$ & & $66.67 \%$ & $59.09 \%$ \\
\hline male & $50.00 \%$ & & $0.00 \%$ & & $33.33 \%$ & $40.91 \%$ \\
\hline Physical damage & $0.00 \%$ & $0.00 \%$ & $0.00 \%$ & $0.00 \%$ & $8.22 \%$ & $3.75 \%$ \\
\hline female & & & & & $16.67 \%$ & $16.67 \%$ \\
\hline male & & & & & $83.33 \%$ & $83.33 \%$ \\
\hline Reptile bites & $0.00 \%$ & $0.00 \%$ & $0.00 \%$ & $0.00 \%$ & $5.48 \%$ & $2.50 \%$ \\
\hline female & & & & & $75.00 \%$ & $75.00 \%$ \\
\hline male & & & & & $25.00 \%$ & $25.00 \%$ \\
\hline Not applicable & $10.53 \%$ & $0.00 \%$ & $0.00 \%$ & $100.00 \%$ & $12.33 \%$ & $17.50 \%$ \\
\hline female & $50.00 \%$ & & & $33.33 \%$ & $11.11 \%$ & $28.57 \%$ \\
\hline male & $50.00 \%$ & & & $66.67 \%$ & $88.89 \%$ & $71.43 \%$ \\
\hline Grand Total & $100.00 \%$ & $100.00 \%$ & $100.00 \%$ & $100.00 \%$ & $100.00 \%$ & $100.00 \%$ \\
\hline
\end{tabular}


Table A3.5: Suggested changes in financial products and services to facilitate soil conservation or land preparation, disaggregated by gender

\begin{tabular}{|c|c|c|c|c|c|c|}
\hline Changes & East Africa & India & $\begin{array}{l}\text { L } \\
\text { America }\end{array}$ & SE Asia & $\begin{array}{l}\text { West } \\
\text { Africa }\end{array}$ & $\begin{array}{l}\text { Grand } \\
\text { Total }\end{array}$ \\
\hline Awareness Creation on Financial services & $0.00 \%$ & $0.00 \%$ & $0.00 \%$ & $0.00 \%$ & $4.17 \%$ & $1.78 \%$ \\
\hline female & & & & & $66.67 \%$ & $66.67 \%$ \\
\hline male & & & & & $33.33 \%$ & $33.33 \%$ \\
\hline Easy Access to financial services & $0.00 \%$ & $0.00 \%$ & $0.00 \%$ & $0.00 \%$ & $11.11 \%$ & $4.73 \%$ \\
\hline female & & & & & $25.00 \%$ & $25.00 \%$ \\
\hline male & & & & & $75.00 \%$ & $75.00 \%$ \\
\hline Lower interest rates & $26.09 \%$ & $15.00 \%$ & $18.75 \%$ & $0.00 \%$ & $2.78 \%$ & $11.83 \%$ \\
\hline female & $41.67 \%$ & $33.33 \%$ & $66.67 \%$ & & $50.00 \%$ & $45.00 \%$ \\
\hline male & $58.33 \%$ & $66.67 \%$ & $33.33 \%$ & & $50.00 \%$ & $55.00 \%$ \\
\hline None & $0.00 \%$ & $35.00 \%$ & $12.50 \%$ & $0.00 \%$ & $22.22 \%$ & $14.79 \%$ \\
\hline female & & $14.29 \%$ & $100.00 \%$ & & $43.75 \%$ & $40.00 \%$ \\
\hline male & & $85.71 \%$ & $0.00 \%$ & & $56.25 \%$ & $60.00 \%$ \\
\hline Other & $26.09 \%$ & $5.00 \%$ & $6.25 \%$ & $0.00 \%$ & $6.94 \%$ & $11.24 \%$ \\
\hline female & $50.00 \%$ & $0.00 \%$ & $100.00 \%$ & & $60.00 \%$ & $52.63 \%$ \\
\hline male & $50.00 \%$ & $100.00 \%$ & $0.00 \%$ & & $40.00 \%$ & $47.37 \%$ \\
\hline They should link us In-Kind & $0.00 \%$ & $0.00 \%$ & $0.00 \%$ & $0.00 \%$ & $6.94 \%$ & $2.96 \%$ \\
\hline female & & & & & $40.00 \%$ & $40.00 \%$ \\
\hline male & & & & & $60.00 \%$ & $60.00 \%$ \\
\hline Training & $28.26 \%$ & $0.00 \%$ & $0.00 \%$ & $0.00 \%$ & $4.17 \%$ & $9.47 \%$ \\
\hline female & $46.15 \%$ & & & & $33.33 \%$ & $43.75 \%$ \\
\hline male & $53.85 \%$ & & & & $66.67 \%$ & $56.25 \%$ \\
\hline More subsidies & $6.52 \%$ & $20.00 \%$ & $62.50 \%$ & $0.00 \%$ & $9.72 \%$ & $14.20 \%$ \\
\hline female & $66.67 \%$ & $25.00 \%$ & $90.00 \%$ & & $71.43 \%$ & $70.83 \%$ \\
\hline male & $33.33 \%$ & $75.00 \%$ & $10.00 \%$ & & $28.57 \%$ & $29.17 \%$ \\
\hline Not applicable & $13.04 \%$ & $25.00 \%$ & $0.00 \%$ & $100.00 \%$ & $31.94 \%$ & $28.99 \%$ \\
\hline female & $66.67 \%$ & $20.00 \%$ & & $33.33 \%$ & $30.43 \%$ & $34.69 \%$ \\
\hline male & $33.33 \%$ & $80.00 \%$ & & $66.67 \%$ & $69.57 \%$ & $65.31 \%$ \\
\hline Grand Total & $100.00 \%$ & $100.00 \%$ & $100.00 \%$ & $100.00 \%$ & $100.00 \%$ & $100.00 \%$ \\
\hline
\end{tabular}

Water use efficiency or conservation technologies and practices

Table A3.6: Water use efficiency or conservation technologies and practices applied, disaggregated by gender

\begin{tabular}{|c|c|c|c|c|c|c|}
\hline Technologies \& practices & East Africa & India & L America & SE Asia & West Africa & Grand Total \\
\hline Alternate wetting and drying & $0.00 \%$ & $7.14 \%$ & $0.00 \%$ & $0.00 \%$ & $0.00 \%$ & $1.42 \%$ \\
\hline female & & $33.33 \%$ & & & & $33.33 \%$ \\
\hline male & & $66.67 \%$ & & & & $66.67 \%$ \\
\hline Bed planting & $0.00 \%$ & $28.57 \%$ & $0.00 \%$ & $0.00 \%$ & $0.00 \%$ & $5.69 \%$ \\
\hline female & & $33.33 \%$ & & & & $33.33 \%$ \\
\hline male & & $66.67 \%$ & & & & $66.67 \%$ \\
\hline Bunding & $0.00 \%$ & $9.52 \%$ & $0.00 \%$ & $0.00 \%$ & $7.23 \%$ & $4.74 \%$ \\
\hline female & & $25.00 \%$ & & & $50.00 \%$ & $40.00 \%$ \\
\hline male & & $75.00 \%$ & & & $50.00 \%$ & $60.00 \%$ \\
\hline Drip irrigation & $0.00 \%$ & $0.00 \%$ & $38.24 \%$ & $0.00 \%$ & $0.00 \%$ & $6.16 \%$ \\
\hline female & & & $92.31 \%$ & & & $92.31 \%$ \\
\hline male & & & $7.69 \%$ & & & $7.69 \%$ \\
\hline DSR & $0.00 \%$ & $11.90 \%$ & $0.00 \%$ & $0.00 \%$ & $0.00 \%$ & $2.37 \%$ \\
\hline
\end{tabular}




\begin{tabular}{|c|c|c|c|c|c|c|}
\hline female & & $60.00 \%$ & & & & $60.00 \%$ \\
\hline male & & $40.00 \%$ & & & & $40.00 \%$ \\
\hline irrigation & $29.73 \%$ & $0.00 \%$ & $0.00 \%$ & $0.00 \%$ & $0.00 \%$ & $5.21 \%$ \\
\hline female & $45.45 \%$ & & & & & $45.45 \%$ \\
\hline male & $54.55 \%$ & & & & & $54.55 \%$ \\
\hline Laser land leveler & $0.00 \%$ & $26.19 \%$ & $0.00 \%$ & $0.00 \%$ & $0.00 \%$ & $5.21 \%$ \\
\hline female & & $18.18 \%$ & & & & $18.18 \%$ \\
\hline male & & $81.82 \%$ & & & & $81.82 \%$ \\
\hline Nutrient management & $2.70 \%$ & $4.76 \%$ & $0.00 \%$ & $0.00 \%$ & $7.23 \%$ & $4.27 \%$ \\
\hline female & $100.00 \%$ & $0.00 \%$ & & & $66.67 \%$ & $55.56 \%$ \\
\hline male & $0.00 \%$ & $100.00 \%$ & & & $33.33 \%$ & $44.44 \%$ \\
\hline Other & $5.41 \%$ & $4.76 \%$ & $8.82 \%$ & $0.00 \%$ & $1.20 \%$ & $3.79 \%$ \\
\hline female & $100.00 \%$ & $0.00 \%$ & $66.67 \%$ & & $100.00 \%$ & $62.50 \%$ \\
\hline male & $0.00 \%$ & $100.00 \%$ & $33.33 \%$ & & $0.00 \%$ & $37.50 \%$ \\
\hline RNA & $0.00 \%$ & $0.00 \%$ & $0.00 \%$ & $0.00 \%$ & $25.30 \%$ & $9.95 \%$ \\
\hline female & & & & & $38.10 \%$ & $38.10 \%$ \\
\hline male & & & & & $61.90 \%$ & $61.90 \%$ \\
\hline Tied ridges & $2.70 \%$ & $0.00 \%$ & $0.00 \%$ & $0.00 \%$ & $24.10 \%$ & $9.95 \%$ \\
\hline female & $100.00 \%$ & & & & $65.00 \%$ & $66.67 \%$ \\
\hline male & $0.00 \%$ & & & & $35.00 \%$ & $33.33 \%$ \\
\hline Water conservation & $35.14 \%$ & $0.00 \%$ & $52.94 \%$ & $0.00 \%$ & $3.61 \%$ & $16.11 \%$ \\
\hline female & $53.85 \%$ & & $72.22 \%$ & & $66.67 \%$ & $64.71 \%$ \\
\hline male & $46.15 \%$ & & $27.78 \%$ & & $33.33 \%$ & $35.29 \%$ \\
\hline Zai Method & $0.00 \%$ & $0.00 \%$ & $0.00 \%$ & $0.00 \%$ & $10.84 \%$ & $4.27 \%$ \\
\hline female & & & & & $33.33 \%$ & $33.33 \%$ \\
\hline male & & & & & $66.67 \%$ & $66.67 \%$ \\
\hline Not applicable & $24.32 \%$ & $7.14 \%$ & $0.00 \%$ & $100.00 \%$ & $20.48 \%$ & $20.85 \%$ \\
\hline female & $55.56 \%$ & $0.00 \%$ & & $33.33 \%$ & $29.41 \%$ & $34.09 \%$ \\
\hline male & $44.44 \%$ & $100.00 \%$ & & $66.67 \%$ & $70.59 \%$ & $65.91 \%$ \\
\hline Grand Total & $100.00 \%$ & $100.00 \%$ & $100.00 \%$ & $100.00 \%$ & $100.00 \%$ & $100.00 \%$ \\
\hline
\end{tabular}

Table A3.7: Amount of investment $(\$)$ in water use efficiency or conservation technologies and practices, disaggregated by gender

\begin{tabular}{|c|c|c|c|c|c|c|c|}
\hline Amount (\$) & East Africa & India & L America & SE Asia & West Africa & (blank) & Grand Total \\
\hline 0 & $0.00 \%$ & $22.22 \%$ & $35.71 \%$ & $0.00 \%$ & $39.39 \%$ & $0.00 \%$ & $23.49 \%$ \\
\hline female & & $25.00 \%$ & $100.00 \%$ & & $38.46 \%$ & & $45.71 \%$ \\
\hline male & & $75.00 \%$ & $0.00 \%$ & & $61.54 \%$ & & $54.29 \%$ \\
\hline $0-50$ & $45.71 \%$ & $5.56 \%$ & $35.71 \%$ & $0.00 \%$ & $25.76 \%$ & $0.00 \%$ & $26.17 \%$ \\
\hline female & $56.25 \%$ & $0.00 \%$ & $80.00 \%$ & & $35.29 \%$ & & $48.72 \%$ \\
\hline male & $43.75 \%$ & $100.00 \%$ & $20.00 \%$ & & $64.71 \%$ & & $51.28 \%$ \\
\hline $50-100$ & $2.86 \%$ & $11.11 \%$ & $7.14 \%$ & $0.00 \%$ & $0.00 \%$ & $0.00 \%$ & $2.68 \%$ \\
\hline female & $100.00 \%$ & $100.00 \%$ & $100.00 \%$ & & & & $100.00 \%$ \\
\hline $100-500$ & $11.43 \%$ & $33.33 \%$ & $21.43 \%$ & $0.00 \%$ & $0.00 \%$ & $0.00 \%$ & $8.72 \%$ \\
\hline female & $0.00 \%$ & $16.67 \%$ & $66.67 \%$ & & & & $23.08 \%$ \\
\hline male & $100.00 \%$ & $83.33 \%$ & $33.33 \%$ & & & & $76.92 \%$ \\
\hline $500-1000$ & $0.00 \%$ & $0.00 \%$ & $0.00 \%$ & $0.00 \%$ & $0.00 \%$ & $100.00 \%$ & $0.67 \%$ \\
\hline (blank) & & & & & & $100.00 \%$ & $100.00 \%$ \\
\hline$>1000$ & $0.00 \%$ & $5.56 \%$ & $0.00 \%$ & $0.00 \%$ & $0.00 \%$ & $0.00 \%$ & $0.67 \%$ \\
\hline male & & $100.00 \%$ & & & & & $100.00 \%$ \\
\hline
\end{tabular}




\begin{tabular}{clllllll}
\hline Not Applicable & $\mathbf{4 0 . 0 0 \%}$ & $\mathbf{2 2 . 2 2} \%$ & $\mathbf{0 . 0 0 \%}$ & $\mathbf{1 0 0 . 0 0 \%}$ & $\mathbf{3 4 . 8 5 \%}$ & $\mathbf{0 . 0 0 \%}$ & $\mathbf{3 7 . 5 8 \%}$ \\
\hline female & $64.29 \%$ & $0.00 \%$ & & $33.33 \%$ & $52.17 \%$ & & $46.43 \%$ \\
male & $35.71 \%$ & $100.00 \%$ & & $66.67 \%$ & $47.83 \%$ & & $53.57 \%$ \\
\hline Grand Total & $\mathbf{1 0 0 . 0 0 \%}$ & $\mathbf{1 0 0 . 0 0 \%}$ & $\mathbf{1 0 0 . 0 0 \%}$ & $\mathbf{1 0 0 . 0 0 \%}$ & $\mathbf{1 0 0 . 0 0 \%}$ & $\mathbf{1 0 0 . 0 0 \%}$ & $\mathbf{1 0 0 . 0 0 \%}$
\end{tabular}

Table A3.8: Sources of finance used for investments in water use efficiency or conservation technologies and practices, disaggregated by gender

\begin{tabular}{|c|c|c|c|c|c|c|}
\hline Sources & East Africa & India & $\begin{array}{l}\mathrm{L} \\
\text { America }\end{array}$ & SE Asia & $\begin{array}{l}\text { West } \\
\text { Africa }\end{array}$ & $\begin{array}{l}\text { Grand } \\
\text { Total }\end{array}$ \\
\hline bank & $0.00 \%$ & $11.11 \%$ & $0.00 \%$ & $0.00 \%$ & $0.00 \%$ & $1.24 \%$ \\
\hline male & & $100.00 \%$ & & & & $100.00 \%$ \\
\hline CCAFS-Ecohabitats project & $0.00 \%$ & $0.00 \%$ & $57.89 \%$ & $0.00 \%$ & $1.47 \%$ & $7.45 \%$ \\
\hline female & & & $90.91 \%$ & & $0.00 \%$ & $83.33 \%$ \\
\hline male & & & $9.09 \%$ & & $100.00 \%$ & $16.67 \%$ \\
\hline Microfinance institution & $2.50 \%$ & $0.00 \%$ & $0.00 \%$ & $0.00 \%$ & $0.00 \%$ & $0.62 \%$ \\
\hline female & $100.00 \%$ & & & & & $100.00 \%$ \\
\hline Other & $0.00 \%$ & $0.00 \%$ & $10.53 \%$ & $0.00 \%$ & $0.00 \%$ & $1.24 \%$ \\
\hline female & & & $100.00 \%$ & & & $100.00 \%$ \\
\hline Remittances funds & $17.50 \%$ & $0.00 \%$ & $0.00 \%$ & $0.00 \%$ & $4.41 \%$ & $6.21 \%$ \\
\hline female & $57.14 \%$ & & & & $66.67 \%$ & $60.00 \%$ \\
\hline male & $42.86 \%$ & & & & $33.33 \%$ & $40.00 \%$ \\
\hline SACCO & $7.50 \%$ & $0.00 \%$ & $0.00 \%$ & $0.00 \%$ & $1.47 \%$ & $2.48 \%$ \\
\hline female & $33.33 \%$ & & & & $0.00 \%$ & $25.00 \%$ \\
\hline male & $66.67 \%$ & & & & $100.00 \%$ & $75.00 \%$ \\
\hline sale of farm products & $0.00 \%$ & $0.00 \%$ & $31.58 \%$ & $0.00 \%$ & $1.47 \%$ & $4.35 \%$ \\
\hline female & & & $66.67 \%$ & & $0.00 \%$ & $57.14 \%$ \\
\hline male & & & $33.33 \%$ & & $100.00 \%$ & $42.86 \%$ \\
\hline Self financed & $12.50 \%$ & $38.89 \%$ & $0.00 \%$ & $0.00 \%$ & $17.65 \%$ & $14.91 \%$ \\
\hline female & $40.00 \%$ & $28.57 \%$ & & & $33.33 \%$ & $33.33 \%$ \\
\hline male & $60.00 \%$ & $71.43 \%$ & & & $66.67 \%$ & $66.67 \%$ \\
\hline Shop keepers & $0.00 \%$ & $0.00 \%$ & $0.00 \%$ & $6.25 \%$ & $0.00 \%$ & $0.62 \%$ \\
\hline male & & & & $100.00 \%$ & & $100.00 \%$ \\
\hline Trader & $2.50 \%$ & $11.11 \%$ & $0.00 \%$ & $0.00 \%$ & $0.00 \%$ & $1.86 \%$ \\
\hline female & $0.00 \%$ & $50.00 \%$ & & & & $33.33 \%$ \\
\hline male & $100.00 \%$ & $50.00 \%$ & & & & $66.67 \%$ \\
\hline VSLA & $0.00 \%$ & $0.00 \%$ & $0.00 \%$ & $0.00 \%$ & $2.94 \%$ & $1.24 \%$ \\
\hline female & & & & & $50.00 \%$ & $50.00 \%$ \\
\hline male & & & & & $50.00 \%$ & $50.00 \%$ \\
\hline Not applicable & $27.50 \%$ & $38.89 \%$ & $0.00 \%$ & $93.75 \%$ & $70.59 \%$ & $50.31 \%$ \\
\hline female & $63.64 \%$ & $14.29 \%$ & & $33.33 \%$ & $43.75 \%$ & $41.98 \%$ \\
\hline male & $36.36 \%$ & $85.71 \%$ & & $66.67 \%$ & $56.25 \%$ & $58.02 \%$ \\
\hline Merry-go-round2 & $25.00 \%$ & $0.00 \%$ & $0.00 \%$ & $0.00 \%$ & $0.00 \%$ & $6.21 \%$ \\
\hline female & $60.00 \%$ & & & & & $60.00 \%$ \\
\hline male & $40.00 \%$ & & & & & $40.00 \%$ \\
\hline Savings collectors & $2.50 \%$ & $0.00 \%$ & $0.00 \%$ & $0.00 \%$ & $0.00 \%$ & $0.62 \%$ \\
\hline male & $100.00 \%$ & & & & & $100.00 \%$ \\
\hline Input supplier & $2.50 \%$ & $0.00 \%$ & $0.00 \%$ & $0.00 \%$ & $0.00 \%$ & $0.62 \%$ \\
\hline male & $100.00 \%$ & & & & & $100.00 \%$ \\
\hline Grand Total & $100.00 \%$ & $100.00 \%$ & $100.00 \%$ & $100.00 \%$ & $100.00 \%$ & $100.00 \%$ \\
\hline
\end{tabular}


Table A3.9: Risks in water use efficiency or conservation technologies and practices, disaggregated by gender

\begin{tabular}{|c|c|c|c|c|c|c|}
\hline Risks & East Africa & India & $\begin{array}{l}\text { L } \\
\text { America }\end{array}$ & SE Asia & $\begin{array}{l}\text { West } \\
\text { Africa }\end{array}$ & $\begin{array}{l}\text { Grand } \\
\text { Total }\end{array}$ \\
\hline Drought & $16.22 \%$ & $0.00 \%$ & $40.00 \%$ & $0.00 \%$ & $0.00 \%$ & $7.84 \%$ \\
\hline female & $50.00 \%$ & & $100.00 \%$ & & & $75.00 \%$ \\
\hline male & $50.00 \%$ & & $0.00 \%$ & & & $25.00 \%$ \\
\hline Erosion & $0.00 \%$ & $0.00 \%$ & $0.00 \%$ & $0.00 \%$ & $4.41 \%$ & $1.96 \%$ \\
\hline female & & & & & $66.67 \%$ & $66.67 \%$ \\
\hline male & & & & & $33.33 \%$ & $33.33 \%$ \\
\hline Expensive to construct water pan & $10.81 \%$ & $0.00 \%$ & $0.00 \%$ & $0.00 \%$ & $0.00 \%$ & $2.61 \%$ \\
\hline female & $75.00 \%$ & & & & & $75.00 \%$ \\
\hline male & $25.00 \%$ & & & & & $25.00 \%$ \\
\hline Injuries digging pits and ridges & $2.70 \%$ & $0.00 \%$ & $0.00 \%$ & $0.00 \%$ & $17.65 \%$ & $8.50 \%$ \\
\hline female & $0.00 \%$ & & & & $50.00 \%$ & $46.15 \%$ \\
\hline male & $100.00 \%$ & & & & $50.00 \%$ & $53.85 \%$ \\
\hline Labour intensive & $5.41 \%$ & $0.00 \%$ & $0.00 \%$ & $0.00 \%$ & $2.94 \%$ & $2.61 \%$ \\
\hline female & $0.00 \%$ & & & & $50.00 \%$ & $25.00 \%$ \\
\hline male & $100.00 \%$ & & & & $50.00 \%$ & $75.00 \%$ \\
\hline None & $0.00 \%$ & $61.11 \%$ & $33.33 \%$ & $0.00 \%$ & $33.82 \%$ & $25.49 \%$ \\
\hline female & & $36.36 \%$ & $60.00 \%$ & & $43.48 \%$ & $43.59 \%$ \\
\hline male & & $63.64 \%$ & $40.00 \%$ & & $56.52 \%$ & $56.41 \%$ \\
\hline Not enough reservoirs & $0.00 \%$ & $0.00 \%$ & $26.67 \%$ & $0.00 \%$ & $1.47 \%$ & $3.27 \%$ \\
\hline female & & & $100.00 \%$ & & $100.00 \%$ & $100.00 \%$ \\
\hline Pests and diseases & $21.62 \%$ & $0.00 \%$ & $0.00 \%$ & $0.00 \%$ & $0.00 \%$ & $5.23 \%$ \\
\hline female & $62.50 \%$ & & & & & $62.50 \%$ \\
\hline male & $37.50 \%$ & & & & & $37.50 \%$ \\
\hline Siltation of water pan & $10.81 \%$ & $0.00 \%$ & $0.00 \%$ & $0.00 \%$ & $0.00 \%$ & $2.61 \%$ \\
\hline female & $75.00 \%$ & & & & & $75.00 \%$ \\
\hline male & $25.00 \%$ & & & & & $25.00 \%$ \\
\hline Snake and scorpion bites & $0.00 \%$ & $0.00 \%$ & $0.00 \%$ & $0.00 \%$ & $5.88 \%$ & $2.61 \%$ \\
\hline female & & & & & $50.00 \%$ & $50.00 \%$ \\
\hline male & & & & & $50.00 \%$ & $50.00 \%$ \\
\hline Weeds & $0.00 \%$ & $16.67 \%$ & $0.00 \%$ & $0.00 \%$ & $0.00 \%$ & $1.96 \%$ \\
\hline male & & $100.00 \%$ & & & & $100.00 \%$ \\
\hline Not applicable & $32.43 \%$ & $22.22 \%$ & $0.00 \%$ & $100.00 \%$ & $33.82 \%$ & $35.29 \%$ \\
\hline female & $58.33 \%$ & $0.00 \%$ & & $33.33 \%$ & $34.78 \%$ & $37.04 \%$ \\
\hline male & $41.67 \%$ & $100.00 \%$ & & $66.67 \%$ & $65.22 \%$ & $62.96 \%$ \\
\hline Grand Total & $100.00 \%$ & $100.00 \%$ & $100.00 \%$ & $100.00 \%$ & $100.00 \%$ & $100.00 \%$ \\
\hline
\end{tabular}


Table A3.10: Suggested changes in financial products and services to facilitate water use efficiency or conservation technologies and practices, disaggregated by gender

\begin{tabular}{|c|c|c|c|c|c|c|}
\hline Changes & East Africa & India & $\begin{array}{l}\text { L } \\
\text { America }\end{array}$ & SE Asia & $\begin{array}{l}\text { West } \\
\text { Africa }\end{array}$ & $\begin{array}{l}\text { Grand } \\
\text { Total }\end{array}$ \\
\hline Lower interest rates & $2.63 \%$ & $11.11 \%$ & $23.53 \%$ & $0.00 \%$ & $11.94 \%$ & $9.68 \%$ \\
\hline female & $100.00 \%$ & $50.00 \%$ & $75.00 \%$ & & $62.50 \%$ & $66.67 \%$ \\
\hline male & $0.00 \%$ & $50.00 \%$ & $25.00 \%$ & & $37.50 \%$ & $33.33 \%$ \\
\hline More subsidy & $0.00 \%$ & $0.00 \%$ & $29.41 \%$ & $0.00 \%$ & $0.00 \%$ & $3.23 \%$ \\
\hline female & & & $100.00 \%$ & & & $100.00 \%$ \\
\hline More subsidy for adaptation & $15.79 \%$ & $0.00 \%$ & $23.53 \%$ & $0.00 \%$ & $5.97 \%$ & $9.03 \%$ \\
\hline female & $50.00 \%$ & & $50.00 \%$ & & $75.00 \%$ & $57.14 \%$ \\
\hline male & $50.00 \%$ & & $50.00 \%$ & & $25.00 \%$ & $42.86 \%$ \\
\hline None & $0.00 \%$ & $44.44 \%$ & $5.88 \%$ & $0.00 \%$ & $22.39 \%$ & $15.48 \%$ \\
\hline female & & $25.00 \%$ & $100.00 \%$ & & $46.67 \%$ & $41.67 \%$ \\
\hline male & & $75.00 \%$ & $0.00 \%$ & & $53.33 \%$ & $58.33 \%$ \\
\hline Soft loan & $15.79 \%$ & $0.00 \%$ & $0.00 \%$ & $0.00 \%$ & $4.48 \%$ & $5.81 \%$ \\
\hline female & $50.00 \%$ & & & & $33.33 \%$ & $44.44 \%$ \\
\hline male & $50.00 \%$ & & & & $66.67 \%$ & $55.56 \%$ \\
\hline Tractor services & $0.00 \%$ & $0.00 \%$ & $0.00 \%$ & $0.00 \%$ & $13.43 \%$ & $5.81 \%$ \\
\hline female & & & & & $33.33 \%$ & $33.33 \%$ \\
\hline male & & & & & $66.67 \%$ & $66.67 \%$ \\
\hline Training & $21.05 \%$ & $0.00 \%$ & $5.88 \%$ & $0.00 \%$ & $1.49 \%$ & $6.45 \%$ \\
\hline female & $50.00 \%$ & & $100.00 \%$ & & $100.00 \%$ & $60.00 \%$ \\
\hline male & $50.00 \%$ & & $0.00 \%$ & & $0.00 \%$ & $40.00 \%$ \\
\hline Training on irrigation & $13.16 \%$ & $0.00 \%$ & $0.00 \%$ & $0.00 \%$ & $0.00 \%$ & $3.23 \%$ \\
\hline female & $40.00 \%$ & & & & & $40.00 \%$ \\
\hline male & $60.00 \%$ & & & & & $60.00 \%$ \\
\hline Not applicable & $31.58 \%$ & $44.44 \%$ & $11.76 \%$ & $100.00 \%$ & $40.30 \%$ & $41.29 \%$ \\
\hline female & $66.67 \%$ & $12.50 \%$ & $100.00 \%$ & $33.33 \%$ & $33.33 \%$ & $39.06 \%$ \\
\hline male & $33.33 \%$ & $87.50 \%$ & $0.00 \%$ & $66.67 \%$ & $66.67 \%$ & $60.94 \%$ \\
\hline Grand Total & $100.00 \%$ & $100.00 \%$ & $100.00 \%$ & $100.00 \%$ & $100.00 \%$ & $100.00 \%$ \\
\hline
\end{tabular}

Weather forecasting services and/or index based insurance

Table A3.11: Weather forecasting services applied and/or index based insurance in use, disaggregated by gender

\begin{tabular}{|c|c|c|c|c|c|c|}
\hline Technologies \& practices & East Africa & India & L America & SE Asia & West Africa & Grand Total \\
\hline Agro advisory & $0.00 \%$ & $21.62 \%$ & $0.00 \%$ & $0.00 \%$ & $53.03 \%$ & $24.71 \%$ \\
\hline female & & $12.50 \%$ & & & $45.71 \%$ & $39.53 \%$ \\
\hline male & & $87.50 \%$ & & & $54.29 \%$ & $60.47 \%$ \\
\hline Ask my neighbour & $0.00 \%$ & $5.41 \%$ & $0.00 \%$ & $4.55 \%$ & $0.00 \%$ & $1.72 \%$ \\
\hline female & & $100.00 \%$ & & $0.00 \%$ & & $66.67 \%$ \\
\hline male & & $0.00 \%$ & & $100.00 \%$ & & $33.33 \%$ \\
\hline Crop Insurance & $0.00 \%$ & $24.32 \%$ & $0.00 \%$ & $0.00 \%$ & $0.00 \%$ & $5.17 \%$ \\
\hline male & & $100.00 \%$ & & & & $100.00 \%$ \\
\hline Indigenous knowledge & $2.86 \%$ & $0.00 \%$ & $0.00 \%$ & $4.55 \%$ & $0.00 \%$ & $1.15 \%$ \\
\hline female & $100.00 \%$ & & & $0.00 \%$ & & $50.00 \%$ \\
\hline male & $0.00 \%$ & & & $100.00 \%$ & & $50.00 \%$ \\
\hline Internet & $0.00 \%$ & $21.62 \%$ & $0.00 \%$ & $13.64 \%$ & $0.00 \%$ & $6.32 \%$ \\
\hline female & & $12.50 \%$ & & $33.33 \%$ & & $18.18 \%$ \\
\hline
\end{tabular}




\begin{tabular}{|c|c|c|c|c|c|c|}
\hline male & & $87.50 \%$ & & $66.67 \%$ & & $81.82 \%$ \\
\hline None & $2.86 \%$ & $5.41 \%$ & $85.71 \%$ & $0.00 \%$ & $1.52 \%$ & $9.20 \%$ \\
\hline female & $100.00 \%$ & $100.00 \%$ & $83.33 \%$ & & $0.00 \%$ & $81.25 \%$ \\
\hline male & $0.00 \%$ & $0.00 \%$ & $16.67 \%$ & & $100.00 \%$ & $18.75 \%$ \\
\hline Phone & $0.00 \%$ & $0.00 \%$ & $0.00 \%$ & $9.09 \%$ & $0.00 \%$ & $1.15 \%$ \\
\hline female & & & & $100.00 \%$ & & $100.00 \%$ \\
\hline Radio & $14.29 \%$ & $0.00 \%$ & $0.00 \%$ & $9.09 \%$ & $0.00 \%$ & $4.02 \%$ \\
\hline female & $100.00 \%$ & & & $50.00 \%$ & & $85.71 \%$ \\
\hline male & $0.00 \%$ & & & $50.00 \%$ & & $14.29 \%$ \\
\hline SMS service & $0.00 \%$ & $21.62 \%$ & $0.00 \%$ & $0.00 \%$ & $0.00 \%$ & $4.60 \%$ \\
\hline female & & $12.50 \%$ & & & & $12.50 \%$ \\
\hline male & & $87.50 \%$ & & & & $87.50 \%$ \\
\hline TV & $2.86 \%$ & $0.00 \%$ & $0.00 \%$ & $59.09 \%$ & $0.00 \%$ & $8.05 \%$ \\
\hline female & $100.00 \%$ & & & $30.77 \%$ & & $35.71 \%$ \\
\hline male & $0.00 \%$ & & & $69.23 \%$ & & $64.29 \%$ \\
\hline Yes & $0.00 \%$ & $0.00 \%$ & $14.29 \%$ & $0.00 \%$ & $36.36 \%$ & $14.94 \%$ \\
\hline female & & & $100.00 \%$ & & $37.50 \%$ & $42.31 \%$ \\
\hline male & & & $0.00 \%$ & & $62.50 \%$ & $57.69 \%$ \\
\hline Not applicable & $77.14 \%$ & $0.00 \%$ & $0.00 \%$ & $0.00 \%$ & $9.09 \%$ & $18.97 \%$ \\
\hline female & $40.74 \%$ & & & & $50.00 \%$ & $42.42 \%$ \\
\hline male & $59.26 \%$ & & & & $50.00 \%$ & $57.58 \%$ \\
\hline Grand Total & $100.00 \%$ & $100.00 \%$ & $100.00 \%$ & $100.00 \%$ & $100.00 \%$ & $100.00 \%$ \\
\hline
\end{tabular}

Table A3.12: Amount of investment $(\$)$ in weather forecasting services and/or index based insurance, disaggregated by gender

\begin{tabular}{|c|c|c|c|c|c|c|c|}
\hline Amount & East Africa & India & L America & SE Asia & West Africa & (blank) & Grand Total \\
\hline 0 & $0.00 \%$ & $33.33 \%$ & $14.29 \%$ & $0.00 \%$ & $48.48 \%$ & $0.00 \%$ & $26.85 \%$ \\
\hline female & & $33.33 \%$ & $100.00 \%$ & & $31.25 \%$ & & $35.00 \%$ \\
\hline male & & $66.67 \%$ & $0.00 \%$ & & $68.75 \%$ & & $65.00 \%$ \\
\hline $0-50$ & $14.29 \%$ & $27.78 \%$ & $0.00 \%$ & $0.00 \%$ & $19.70 \%$ & $0.00 \%$ & $15.44 \%$ \\
\hline female & $40.00 \%$ & $0.00 \%$ & & & $30.77 \%$ & & $26.09 \%$ \\
\hline male & $60.00 \%$ & $100.00 \%$ & & & $69.23 \%$ & & $73.91 \%$ \\
\hline $50-100$ & $0.00 \%$ & $5.56 \%$ & $0.00 \%$ & $0.00 \%$ & $1.52 \%$ & $0.00 \%$ & $1.34 \%$ \\
\hline female & & $0.00 \%$ & & & $100.00 \%$ & & $50.00 \%$ \\
\hline male & & $100.00 \%$ & & & $0.00 \%$ & & $50.00 \%$ \\
\hline $100-500$ & $0.00 \%$ & $0.00 \%$ & $0.00 \%$ & $0.00 \%$ & $1.52 \%$ & $0.00 \%$ & $0.67 \%$ \\
\hline male & & & & & $100.00 \%$ & & $100.00 \%$ \\
\hline $500-1000$ & $0.00 \%$ & $5.56 \%$ & $0.00 \%$ & $0.00 \%$ & $0.00 \%$ & $0.00 \%$ & $0.67 \%$ \\
\hline male & & $100.00 \%$ & & & & & $100.00 \%$ \\
\hline$>1000$ & $0.00 \%$ & $0.00 \%$ & $0.00 \%$ & $0.00 \%$ & $0.00 \%$ & $100.00 \%$ & $0.67 \%$ \\
\hline (blank) & & & & & & $100.00 \%$ & $100.00 \%$ \\
\hline Not applicable & $85.71 \%$ & $27.78 \%$ & $85.71 \%$ & $100.00 \%$ & $28.79 \%$ & $0.00 \%$ & $54.36 \%$ \\
\hline female & $56.67 \%$ & $40.00 \%$ & $83.33 \%$ & $33.33 \%$ & $68.42 \%$ & & $58.02 \%$ \\
\hline male & $43.33 \%$ & $60.00 \%$ & $16.67 \%$ & $66.67 \%$ & $31.58 \%$ & & $41.98 \%$ \\
\hline Grand Total & $100.00 \%$ & $100.00 \%$ & $100.00 \%$ & $100.00 \%$ & $100.00 \%$ & $100.00 \%$ & $100.00 \%$ \\
\hline
\end{tabular}


Table A3.13: Sources used to invest in weather forecasting services and/or index based insurance, disaggregated by gender

\begin{tabular}{|c|c|c|c|c|c|c|}
\hline Sources & East Africa & India & $\begin{array}{l}\mathbf{L} \\
\text { America }\end{array}$ & SE Asia & $\begin{array}{l}\text { West } \\
\text { Africa }\end{array}$ & $\begin{array}{l}\text { Grand } \\
\text { Total }\end{array}$ \\
\hline Bank & $0.00 \%$ & $11.11 \%$ & $0.00 \%$ & $0.00 \%$ & $0.00 \%$ & $1.32 \%$ \\
\hline male & & $100.00 \%$ & & & & $100.00 \%$ \\
\hline CCAFS-Ecohabitats project & $0.00 \%$ & $0.00 \%$ & $14.29 \%$ & $0.00 \%$ & $5.88 \%$ & $3.97 \%$ \\
\hline female & & & $100.00 \%$ & & $75.00 \%$ & $83.33 \%$ \\
\hline male & & & $0.00 \%$ & & $25.00 \%$ & $16.67 \%$ \\
\hline Cooperative & $0.00 \%$ & $0.00 \%$ & $0.00 \%$ & $0.00 \%$ & $1.47 \%$ & $0.66 \%$ \\
\hline male & & & & & $100.00 \%$ & $100.00 \%$ \\
\hline ESOKO & $0.00 \%$ & $0.00 \%$ & $0.00 \%$ & $0.00 \%$ & $10.29 \%$ & $4.64 \%$ \\
\hline female & & & & & $42.86 \%$ & $42.86 \%$ \\
\hline male & & & & & $57.14 \%$ & $57.14 \%$ \\
\hline Merry-go-round & $11.11 \%$ & $0.00 \%$ & $0.00 \%$ & $0.00 \%$ & $0.00 \%$ & $2.65 \%$ \\
\hline female & $100.00 \%$ & & & & & $100.00 \%$ \\
\hline Other & $0.00 \%$ & $0.00 \%$ & $0.00 \%$ & $0.00 \%$ & $4.41 \%$ & $1.99 \%$ \\
\hline female & & & & & $33.33 \%$ & $33.33 \%$ \\
\hline male & & & & & $66.67 \%$ & $66.67 \%$ \\
\hline Remittances funds & $5.56 \%$ & $0.00 \%$ & $0.00 \%$ & $0.00 \%$ & $1.47 \%$ & $1.99 \%$ \\
\hline female & $100.00 \%$ & & & & $100.00 \%$ & $100.00 \%$ \\
\hline Self-financed & $8.33 \%$ & $27.78 \%$ & $0.00 \%$ & $0.00 \%$ & $10.29 \%$ & $9.93 \%$ \\
\hline female & $0.00 \%$ & $0.00 \%$ & & & $57.14 \%$ & $26.67 \%$ \\
\hline male & $100.00 \%$ & $100.00 \%$ & & & $42.86 \%$ & $73.33 \%$ \\
\hline VSLA & $0.00 \%$ & $0.00 \%$ & $0.00 \%$ & $0.00 \%$ & $1.47 \%$ & $0.66 \%$ \\
\hline male & & & & & $100.00 \%$ & $100.00 \%$ \\
\hline Not applicable & $75.00 \%$ & $61.11 \%$ & $85.71 \%$ & $100.00 \%$ & $64.71 \%$ & $72.19 \%$ \\
\hline female & $51.85 \%$ & $36.36 \%$ & $83.33 \%$ & $33.33 \%$ & $40.91 \%$ & $46.79 \%$ \\
\hline male & $48.15 \%$ & $63.64 \%$ & $16.67 \%$ & $66.67 \%$ & $59.09 \%$ & $53.21 \%$ \\
\hline Grand Total & $100.00 \%$ & $100.00 \%$ & $100.00 \%$ & $100.00 \%$ & $100.00 \%$ & $100.00 \%$ \\
\hline
\end{tabular}

Table A3.14: Risks in weather forecasting services and/or index based insurance, disaggregated by gender

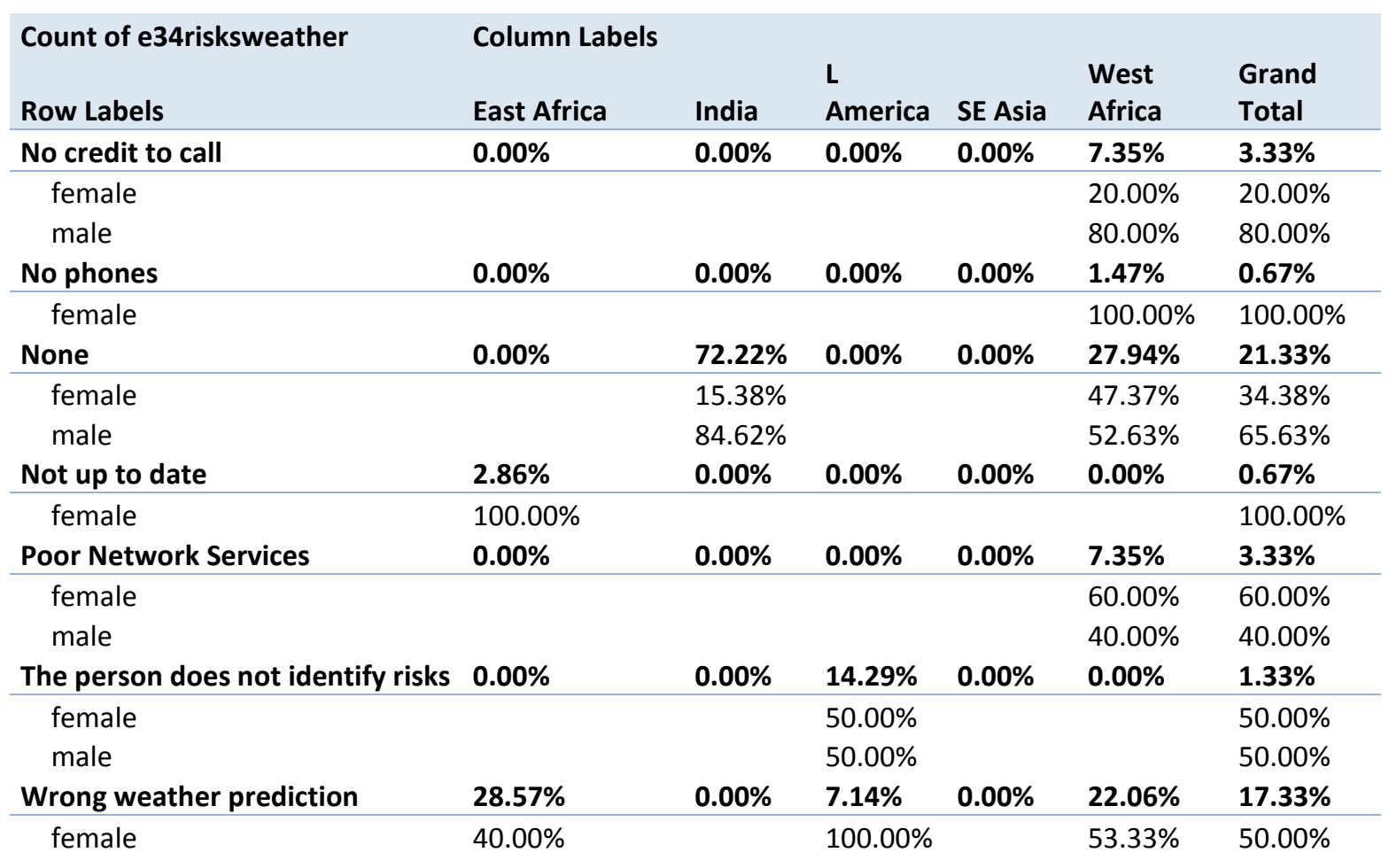




\begin{tabular}{cllllll} 
male & $60.00 \%$ & & $0.00 \%$ & & $46.67 \%$ & $50.00 \%$ \\
Not applicable & $\mathbf{6 8 . 5 7 \%}$ & $\mathbf{2 7 . 7 8 \%}$ & $\mathbf{7 8 . 5 7 \%}$ & $\mathbf{1 0 0 . 0 0 \%}$ & $\mathbf{3 3 . 8 2 \%}$ & $\mathbf{5 2 . 0 0 \%}$ \\
\hline female & $58.33 \%$ & $40.00 \%$ & $90.91 \%$ & $33.33 \%$ & $30.43 \%$ & $48.72 \%$ \\
male & $41.67 \%$ & $60.00 \%$ & $9.09 \%$ & $66.67 \%$ & $69.57 \%$ & $51.28 \%$ \\
\hline Grand Total & $\mathbf{1 0 0 . 0 0 \%}$ & $\mathbf{1 0 0 . 0 0 \%}$ & $\mathbf{1 0 0 . 0 0 \%}$ & $\mathbf{1 0 0 . 0 0 \%}$ & $\mathbf{1 0 0 . 0 0 \%}$ & $\mathbf{1 0 0 . 0 0 \%}$
\end{tabular}

Table A3.15: Suggested changes in financial products and services to facilitate weather forecasting services and/or index based insurance, disaggregated by gender

\begin{tabular}{|c|c|c|c|c|c|c|}
\hline Changes & East Africa & India & $\begin{array}{l}\text { L } \\
\text { America }\end{array}$ & SE Asia & $\begin{array}{l}\text { West } \\
\text { Africa }\end{array}$ & $\begin{array}{l}\text { Grand } \\
\text { Total }\end{array}$ \\
\hline Flexible Loans & $8.11 \%$ & $0.00 \%$ & $0.00 \%$ & $0.00 \%$ & $8.33 \%$ & $5.77 \%$ \\
\hline female & $66.67 \%$ & & & & $83.33 \%$ & $77.78 \%$ \\
\hline male & $33.33 \%$ & & & & $16.67 \%$ & $22.22 \%$ \\
\hline Free weather forecast & $0.00 \%$ & $0.00 \%$ & $21.43 \%$ & $0.00 \%$ & $0.00 \%$ & $1.92 \%$ \\
\hline female & & & $66.67 \%$ & & & $66.67 \%$ \\
\hline male & & & $33.33 \%$ & & & $33.33 \%$ \\
\hline Lower interest rates & $0.00 \%$ & $5.56 \%$ & $0.00 \%$ & $0.00 \%$ & $15.28 \%$ & $7.69 \%$ \\
\hline female & & $0.00 \%$ & & & $63.64 \%$ & $58.33 \%$ \\
\hline male & & $100.00 \%$ & & & $36.36 \%$ & $41.67 \%$ \\
\hline Market information & $5.41 \%$ & $0.00 \%$ & $0.00 \%$ & $0.00 \%$ & $0.00 \%$ & $1.28 \%$ \\
\hline male & $100.00 \%$ & & & & & $100.00 \%$ \\
\hline $\begin{array}{l}\text { More location and language specific } \\
\text { forecast }\end{array}$ & $0.00 \%$ & $0.00 \%$ & $0.00 \%$ & $0.00 \%$ & $6.94 \%$ & $3.21 \%$ \\
\hline male & & & & & $100.00 \%$ & $100.00 \%$ \\
\hline More location specific forecast & $0.00 \%$ & $0.00 \%$ & $0.00 \%$ & $0.00 \%$ & $9.72 \%$ & $4.49 \%$ \\
\hline female & & & & & $28.57 \%$ & $28.57 \%$ \\
\hline male & & & & & $71.43 \%$ & $71.43 \%$ \\
\hline More subsidy & $16.22 \%$ & $0.00 \%$ & $0.00 \%$ & $0.00 \%$ & $6.94 \%$ & $7.05 \%$ \\
\hline female & $50.00 \%$ & & & & $60.00 \%$ & $54.55 \%$ \\
\hline male & $50.00 \%$ & & & & $40.00 \%$ & $45.45 \%$ \\
\hline None & $0.00 \%$ & $38.89 \%$ & $7.14 \%$ & $0.00 \%$ & $20.83 \%$ & $14.74 \%$ \\
\hline female & & $14.29 \%$ & $100.00 \%$ & & $46.67 \%$ & $39.13 \%$ \\
\hline male & & $85.71 \%$ & $0.00 \%$ & & $53.33 \%$ & $60.87 \%$ \\
\hline Training & $13.51 \%$ & $0.00 \%$ & $7.14 \%$ & $0.00 \%$ & $0.00 \%$ & $3.85 \%$ \\
\hline female & $60.00 \%$ & & $0.00 \%$ & & & $50.00 \%$ \\
\hline male & $40.00 \%$ & & $100.00 \%$ & & & $50.00 \%$ \\
\hline Not applicable & $56.76 \%$ & $55.56 \%$ & $64.29 \%$ & $100.00 \%$ & $31.94 \%$ & $50.00 \%$ \\
\hline female & $57.14 \%$ & $30.00 \%$ & $100.00 \%$ & $33.33 \%$ & $39.13 \%$ & $48.72 \%$ \\
\hline male & $42.86 \%$ & $70.00 \%$ & $0.00 \%$ & $66.67 \%$ & $60.87 \%$ & $51.28 \%$ \\
\hline Grand Total & $100.00 \%$ & $100.00 \%$ & $100.00 \%$ & $100.00 \%$ & $100.00 \%$ & $100.00 \%$ \\
\hline
\end{tabular}

Nutrient management technologies and practices

Table A3.16: Types of nutrient management technologies and practices applied, disaggregated by gender

\begin{tabular}{cllllll} 
Technologies \& practices & East Africa & India & $\begin{array}{l}\text { L } \\
\text { America }\end{array}$ & SE Asia & $\begin{array}{l}\text { West } \\
\text { Africa }\end{array}$ & $\begin{array}{l}\text { Grand } \\
\text { Total }\end{array}$ \\
\hline Chemical fertilizer & $\mathbf{2 8 . 0 7 \%}$ & $\mathbf{0 . 0 0 \%}$ & $\mathbf{2 0 . 4 5 \%}$ & $\mathbf{0 . 0 0 \%}$ & $\mathbf{1 5 . 2 4 \%}$ & $\mathbf{1 5 . 0 7 \%}$ \\
\hline $\begin{array}{c}\text { female } \\
\text { male }\end{array}$ & $\mathbf{4 3 . 7 5 \%}$ & & $88.89 \%$ & & $50.00 \%$ & $56.10 \%$ \\
Cover crop & $56.25 \%$ & & $11.11 \%$ & & $50.00 \%$ & $43.90 \%$ \\
\hline female & $\mathbf{1 . 7 5 \%}$ & $\mathbf{7 . 8 4 \%}$ & $\mathbf{0 . 0 0 \%}$ & $\mathbf{0 . 0 0 \%}$ & $\mathbf{0 . 0 0 \%}$ & $\mathbf{1 . 8 4 \%}$ \\
$\quad$ male & $100.00 \%$ & $0.00 \%$ & & & & $\mathbf{2 0 . 0 0 \%}$ \\
& $0.00 \%$ & $100.00 \%$ & & & & $80.00 \%$
\end{tabular}




\begin{tabular}{|c|c|c|c|c|c|c|}
\hline Crop residues on top soils & $7.02 \%$ & $0.00 \%$ & $22.73 \%$ & $0.00 \%$ & $1.90 \%$ & $5.88 \%$ \\
\hline female & $25.00 \%$ & & $80.00 \%$ & & $50.00 \%$ & $62.50 \%$ \\
\hline male & $75.00 \%$ & & $20.00 \%$ & & $50.00 \%$ & $37.50 \%$ \\
\hline Crop Rotation & $5.26 \%$ & $0.00 \%$ & $0.00 \%$ & $0.00 \%$ & $7.62 \%$ & $4.04 \%$ \\
\hline female & $66.67 \%$ & & & & $50.00 \%$ & $54.55 \%$ \\
\hline male & $33.33 \%$ & & & & $50.00 \%$ & $45.45 \%$ \\
\hline Green seeker Crop Sensing System & $0.00 \%$ & $27.45 \%$ & $0.00 \%$ & $0.00 \%$ & $0.00 \%$ & $5.15 \%$ \\
\hline female & & $28.57 \%$ & & & & $28.57 \%$ \\
\hline male & & $71.43 \%$ & & & & $71.43 \%$ \\
\hline Growing leguminous crop & $1.75 \%$ & $0.00 \%$ & $0.00 \%$ & $0.00 \%$ & $0.95 \%$ & $0.74 \%$ \\
\hline female & $0.00 \%$ & & & & $100.00 \%$ & $50.00 \%$ \\
\hline male & $100.00 \%$ & & & & $0.00 \%$ & $50.00 \%$ \\
\hline Improved seeds & $7.02 \%$ & $0.00 \%$ & $0.00 \%$ & $0.00 \%$ & $0.00 \%$ & $1.47 \%$ \\
\hline female & $50.00 \%$ & & & & & $50.00 \%$ \\
\hline male & $50.00 \%$ & & & & & $50.00 \%$ \\
\hline Integrated nutrient management & $0.00 \%$ & $29.41 \%$ & $0.00 \%$ & $0.00 \%$ & $0.00 \%$ & $5.51 \%$ \\
\hline female & & $26.67 \%$ & & & & $26.67 \%$ \\
\hline male & & $73.33 \%$ & & & & $73.33 \%$ \\
\hline Manure & $29.82 \%$ & $3.92 \%$ & $27.27 \%$ & $0.00 \%$ & $33.33 \%$ & $24.26 \%$ \\
\hline female & $70.59 \%$ & $50.00 \%$ & $91.67 \%$ & & $42.86 \%$ & $59.09 \%$ \\
\hline male & $29.41 \%$ & $50.00 \%$ & $8.33 \%$ & & $57.14 \%$ & $40.91 \%$ \\
\hline Mix cropping & $3.51 \%$ & $0.00 \%$ & $0.00 \%$ & $0.00 \%$ & $2.86 \%$ & $1.84 \%$ \\
\hline female & $100.00 \%$ & & & & $33.33 \%$ & $60.00 \%$ \\
\hline male & $0.00 \%$ & & & & $66.67 \%$ & $40.00 \%$ \\
\hline Other & $3.51 \%$ & $0.00 \%$ & $0.00 \%$ & $0.00 \%$ & $7.62 \%$ & $3.68 \%$ \\
\hline female & $50.00 \%$ & & & & $50.00 \%$ & $50.00 \%$ \\
\hline male & $50.00 \%$ & & & & $50.00 \%$ & $50.00 \%$ \\
\hline PH neutralization with lime & $0.00 \%$ & $0.00 \%$ & $29.55 \%$ & $0.00 \%$ & $0.00 \%$ & $4.78 \%$ \\
\hline female & & & $84.62 \%$ & & & $84.62 \%$ \\
\hline male & & & $15.38 \%$ & & & $15.38 \%$ \\
\hline Compost2 & $1.75 \%$ & $25.49 \%$ & $0.00 \%$ & $0.00 \%$ & $16.19 \%$ & $11.40 \%$ \\
\hline female & $0.00 \%$ & $15.38 \%$ & & & $52.94 \%$ & $35.48 \%$ \\
\hline male & $100.00 \%$ & $84.62 \%$ & & & $47.06 \%$ & $64.52 \%$ \\
\hline Not applicable & $10.53 \%$ & $5.88 \%$ & $0.00 \%$ & $100.00 \%$ & $14.29 \%$ & $14.34 \%$ \\
\hline female & $66.67 \%$ & $0.00 \%$ & & $33.33 \%$ & $26.67 \%$ & $33.33 \%$ \\
\hline male & $33.33 \%$ & $100.00 \%$ & & $66.67 \%$ & $73.33 \%$ & $66.67 \%$ \\
\hline Grand Total & $100.00 \%$ & $100.00 \%$ & $100.00 \%$ & $100.00 \%$ & $100.00 \%$ & $100.00 \%$ \\
\hline
\end{tabular}

Table A3.17: Investment amount (\$) in nutrient management technologies and practices in the past year, disaggregated by gender

\begin{tabular}{cllllll} 
Amount(\$) & East Africa & India & LAmerica & SE Asia & West Africa & Grand Total \\
\hline $\mathbf{0}$ & $\mathbf{2 . 8 6 \%}$ & $\mathbf{1 1 . 1 1 \%}$ & $\mathbf{0 . 0 0 \%}$ & $\mathbf{0 . 0 0 \%}$ & $\mathbf{2 5 . 7 6 \%}$ & $\mathbf{1 3 . 5 1 \%}$ \\
\hline female & $100.00 \%$ & $0.00 \%$ & & & $17.65 \%$ & $20.00 \%$ \\
male & $0.00 \%$ & $100.00 \%$ & & & $82.35 \%$ & $80.00 \%$ \\
$\mathbf{0 - 5 0}$ & $\mathbf{6 2 . 8 6 \%}$ & $\mathbf{0 . 0 0 \%}$ & $\mathbf{1 4 . 2 9} \%$ & $\mathbf{0 . 0 0 \%}$ & $\mathbf{2 8 . 7 9 \%}$ & $\mathbf{2 9 . 0 5 \%}$ \\
\hline female & $54.55 \%$ & & $100.00 \%$ & & $47.37 \%$ & $53.49 \%$ \\
male & $45.45 \%$ & & $0.00 \%$ & & $52.63 \%$ & $46.51 \%$
\end{tabular}




\begin{tabular}{|c|c|c|c|c|c|c|}
\hline $50-100$ & $5.71 \%$ & $11.11 \%$ & $14.29 \%$ & $0.00 \%$ & $9.09 \%$ & $8.11 \%$ \\
\hline female & $50.00 \%$ & $50.00 \%$ & $100.00 \%$ & & $66.67 \%$ & $66.67 \%$ \\
\hline male & $50.00 \%$ & $50.00 \%$ & $0.00 \%$ & & $33.33 \%$ & $33.33 \%$ \\
\hline $100-500$ & $2.86 \%$ & $33.33 \%$ & $42.86 \%$ & $0.00 \%$ & $13.64 \%$ & $14.86 \%$ \\
\hline female & $0.00 \%$ & $50.00 \%$ & $83.33 \%$ & & $55.56 \%$ & $59.09 \%$ \\
\hline male & $100.00 \%$ & $50.00 \%$ & $16.67 \%$ & & $44.44 \%$ & $40.91 \%$ \\
\hline $500-1000$ & $0.00 \%$ & $16.67 \%$ & $28.57 \%$ & $0.00 \%$ & $0.00 \%$ & $4.73 \%$ \\
\hline female & & $0.00 \%$ & $75.00 \%$ & & & $42.86 \%$ \\
\hline male & & $100.00 \%$ & $25.00 \%$ & & & $57.14 \%$ \\
\hline$>1000$ & $0.00 \%$ & $11.11 \%$ & $0.00 \%$ & $0.00 \%$ & $0.00 \%$ & $1.35 \%$ \\
\hline male & & $100.00 \%$ & & & & $100.00 \%$ \\
\hline Not Applicable & $25.71 \%$ & $16.67 \%$ & $0.00 \%$ & $100.00 \%$ & $22.73 \%$ & $28.38 \%$ \\
\hline female & $55.56 \%$ & $0.00 \%$ & & $33.33 \%$ & $46.67 \%$ & $40.48 \%$ \\
\hline male & $44.44 \%$ & $100.00 \%$ & & $66.67 \%$ & $53.33 \%$ & $59.52 \%$ \\
\hline Grand Total & $100.00 \%$ & $100.00 \%$ & $100.00 \%$ & $100.00 \%$ & $100.00 \%$ & $100.00 \%$ \\
\hline
\end{tabular}

Table A3.18: Sources of finance used for paying nutrient management technologies and practices last year, disaggregated by gender

\begin{tabular}{|c|c|c|c|c|c|c|}
\hline Sources & East Africa & India & $\begin{array}{l}\text { L } \\
\text { America }\end{array}$ & SE Asia & $\begin{array}{l}\text { West } \\
\text { Africa }\end{array}$ & $\begin{array}{l}\text { Grand } \\
\text { Total }\end{array}$ \\
\hline A money guard & $2.33 \%$ & $0.00 \%$ & $0.00 \%$ & $0.00 \%$ & $1.33 \%$ & $1.21 \%$ \\
\hline female & $0.00 \%$ & & & & $100.00 \%$ & $50.00 \%$ \\
\hline male & $100.00 \%$ & & & & $0.00 \%$ & $50.00 \%$ \\
\hline Bank & $0.00 \%$ & $5.56 \%$ & $0.00 \%$ & $0.00 \%$ & $0.00 \%$ & $0.61 \%$ \\
\hline male & & $100.00 \%$ & & & & $100.00 \%$ \\
\hline Input supplier & $13.95 \%$ & $0.00 \%$ & $0.00 \%$ & $0.00 \%$ & $1.33 \%$ & $4.24 \%$ \\
\hline female & $50.00 \%$ & & & & $0.00 \%$ & $42.86 \%$ \\
\hline male & $50.00 \%$ & & & & $100.00 \%$ & $57.14 \%$ \\
\hline Merry-go-round & $23.26 \%$ & $0.00 \%$ & $0.00 \%$ & $0.00 \%$ & $4.00 \%$ & $7.88 \%$ \\
\hline female & $70.00 \%$ & & & & $100.00 \%$ & $76.92 \%$ \\
\hline male & $30.00 \%$ & & & & $0.00 \%$ & $23.08 \%$ \\
\hline Other & $0.00 \%$ & $0.00 \%$ & $7.14 \%$ & $0.00 \%$ & $5.33 \%$ & $3.03 \%$ \\
\hline female & & & $100.00 \%$ & & $100.00 \%$ & $100.00 \%$ \\
\hline Remittances funds & $9.30 \%$ & $0.00 \%$ & $0.00 \%$ & $0.00 \%$ & $8.00 \%$ & $6.06 \%$ \\
\hline female & $50.00 \%$ & & & & $66.67 \%$ & $60.00 \%$ \\
\hline male & $50.00 \%$ & & & & $33.33 \%$ & $40.00 \%$ \\
\hline SACCO & $6.98 \%$ & $0.00 \%$ & $0.00 \%$ & $0.00 \%$ & $1.33 \%$ & $2.42 \%$ \\
\hline female & $33.33 \%$ & & & & $0.00 \%$ & $25.00 \%$ \\
\hline male & $66.67 \%$ & & & & $100.00 \%$ & $75.00 \%$ \\
\hline Sale of farm products & $0.00 \%$ & $0.00 \%$ & $85.71 \%$ & $0.00 \%$ & $5.33 \%$ & $9.70 \%$ \\
\hline female & & & $83.33 \%$ & & $75.00 \%$ & $81.25 \%$ \\
\hline male & & & $16.67 \%$ & & $25.00 \%$ & $18.75 \%$ \\
\hline Savings collectors & $2.33 \%$ & $0.00 \%$ & $0.00 \%$ & $0.00 \%$ & $2.67 \%$ & $1.82 \%$ \\
\hline female & $0.00 \%$ & & & & $50.00 \%$ & $33.33 \%$ \\
\hline
\end{tabular}




\begin{tabular}{|c|c|c|c|c|c|c|}
\hline male & $100.00 \%$ & & & & $50.00 \%$ & $66.67 \%$ \\
\hline Self-financed & $6.98 \%$ & $61.11 \%$ & $7.14 \%$ & $0.00 \%$ & $26.67 \%$ & $21.21 \%$ \\
\hline female & $66.67 \%$ & $27.27 \%$ & $100.00 \%$ & & $45.00 \%$ & $42.86 \%$ \\
\hline male & $33.33 \%$ & $72.73 \%$ & $0.00 \%$ & & $55.00 \%$ & $57.14 \%$ \\
\hline Trader & $4.65 \%$ & $11.11 \%$ & $0.00 \%$ & $0.00 \%$ & $1.33 \%$ & $3.03 \%$ \\
\hline female & $0.00 \%$ & $50.00 \%$ & & & $100.00 \%$ & $40.00 \%$ \\
\hline male & $100.00 \%$ & $50.00 \%$ & & & $0.00 \%$ & $60.00 \%$ \\
\hline VSLA & $4.65 \%$ & $0.00 \%$ & $0.00 \%$ & $0.00 \%$ & $4.00 \%$ & $3.03 \%$ \\
\hline female & $50.00 \%$ & & & & $33.33 \%$ & $40.00 \%$ \\
\hline male & $50.00 \%$ & & & & $66.67 \%$ & $60.00 \%$ \\
\hline Cooperative & $2.33 \%$ & $0.00 \%$ & $0.00 \%$ & $0.00 \%$ & $0.00 \%$ & $0.61 \%$ \\
\hline female & $100.00 \%$ & & & & & $100.00 \%$ \\
\hline Not applicable & $23.26 \%$ & $22.22 \%$ & $0.00 \%$ & $100.00 \%$ & $38.67 \%$ & $35.15 \%$ \\
\hline female & $60.00 \%$ & $0.00 \%$ & & $33.33 \%$ & $27.59 \%$ & $32.76 \%$ \\
\hline male & $40.00 \%$ & $100.00 \%$ & & $66.67 \%$ & $72.41 \%$ & $67.24 \%$ \\
\hline Grand Total & $100.00 \%$ & $100.00 \%$ & $100.00 \%$ & $100.00 \%$ & $100.00 \%$ & $100.00 \%$ \\
\hline
\end{tabular}

Table A3.19: Risks in nutrient management technologies and practices, disaggregated by gender

\begin{tabular}{|c|c|c|c|c|c|c|}
\hline Risks & East Africa & India & $\begin{array}{l}\text { L } \\
\text { America }\end{array}$ & SE Asia & $\begin{array}{l}\text { West } \\
\text { Africa }\end{array}$ & $\begin{array}{l}\text { Grand } \\
\text { Total }\end{array}$ \\
\hline Availability of materials & $5.41 \%$ & $0.00 \%$ & $0.00 \%$ & $0.00 \%$ & $1.47 \%$ & $1.91 \%$ \\
\hline female & $50.00 \%$ & & & & $100.00 \%$ & $66.67 \%$ \\
\hline male & $50.00 \%$ & & & & $0.00 \%$ & $33.33 \%$ \\
\hline Climatic conditions & $8.11 \%$ & $0.00 \%$ & $0.00 \%$ & $0.00 \%$ & $0.00 \%$ & $1.91 \%$ \\
\hline female & $33.33 \%$ & & & & & $33.33 \%$ \\
\hline male & $66.67 \%$ & & & & & $66.67 \%$ \\
\hline Drought & $16.22 \%$ & $0.00 \%$ & $10.53 \%$ & $0.00 \%$ & $1.47 \%$ & $5.73 \%$ \\
\hline female & $33.33 \%$ & & $100.00 \%$ & & $100.00 \%$ & $55.56 \%$ \\
\hline male & $66.67 \%$ & & $0.00 \%$ & & $0.00 \%$ & $44.44 \%$ \\
\hline Erosion & $2.70 \%$ & $0.00 \%$ & $0.00 \%$ & $0.00 \%$ & $1.47 \%$ & $1.27 \%$ \\
\hline male & $100.00 \%$ & & & & $100.00 \%$ & $100.00 \%$ \\
\hline Excessive rainfall & $0.00 \%$ & $0.00 \%$ & $15.79 \%$ & $0.00 \%$ & $0.00 \%$ & $1.91 \%$ \\
\hline female & & & $100.00 \%$ & & & $100.00 \%$ \\
\hline Expensive & $13.51 \%$ & $0.00 \%$ & $0.00 \%$ & $0.00 \%$ & $2.94 \%$ & $4.46 \%$ \\
\hline female & $60.00 \%$ & & & & $50.00 \%$ & $57.14 \%$ \\
\hline male & $40.00 \%$ & & & & $50.00 \%$ & $42.86 \%$ \\
\hline Injuries digging pits and ridges & $0.00 \%$ & $0.00 \%$ & $0.00 \%$ & $0.00 \%$ & $14.71 \%$ & $6.37 \%$ \\
\hline female & & & & & $70.00 \%$ & $70.00 \%$ \\
\hline male & & & & & $30.00 \%$ & $30.00 \%$ \\
\hline Labour intensive & $0.00 \%$ & $11.11 \%$ & $0.00 \%$ & $0.00 \%$ & $4.41 \%$ & $3.18 \%$ \\
\hline male & & $100.00 \%$ & & & $100.00 \%$ & $100.00 \%$ \\
\hline Leaching & $5.41 \%$ & $0.00 \%$ & $0.00 \%$ & $0.00 \%$ & $0.00 \%$ & $1.27 \%$ \\
\hline female & $50.00 \%$ & & & & & $50.00 \%$ \\
\hline male & $50.00 \%$ & & & & & $50.00 \%$ \\
\hline None & $0.00 \%$ & $72.22 \%$ & $21.05 \%$ & $0.00 \%$ & $23.53 \%$ & $21.02 \%$ \\
\hline female & & $30.77 \%$ & $75.00 \%$ & & $43.75 \%$ & $42.42 \%$ \\
\hline male & & $69.23 \%$ & $25.00 \%$ & & $56.25 \%$ & $57.58 \%$ \\
\hline Other & $10.81 \%$ & $0.00 \%$ & $5.26 \%$ & $0.00 \%$ & $4.41 \%$ & $5.10 \%$ \\
\hline female & $50.00 \%$ & & $100.00 \%$ & & $33.33 \%$ & $50.00 \%$ \\
\hline male & $50.00 \%$ & & $0.00 \%$ & & $66.67 \%$ & $50.00 \%$ \\
\hline Pests and diseases & $2.70 \%$ & $0.00 \%$ & $42.11 \%$ & $0.00 \%$ & $0.00 \%$ & $5.73 \%$ \\
\hline female & $100.00 \%$ & & $87.50 \%$ & & & $88.89 \%$ \\
\hline
\end{tabular}




\begin{tabular}{|c|c|c|c|c|c|c|}
\hline male & $0.00 \%$ & & $12.50 \%$ & & & $11.11 \%$ \\
\hline Snake and scorpion bites & $0.00 \%$ & $0.00 \%$ & $0.00 \%$ & $0.00 \%$ & $11.76 \%$ & $5.10 \%$ \\
\hline female & & & & & $62.50 \%$ & $62.50 \%$ \\
\hline male & & & & & $37.50 \%$ & $37.50 \%$ \\
\hline $\begin{array}{l}\text { Poor knowledge of } \\
\text { fertilizer }\end{array}$ & $5.41 \%$ & $0.00 \%$ & $5.26 \%$ & $0.00 \%$ & $1.47 \%$ & $2.55 \%$ \\
\hline female & $50.00 \%$ & & $100.00 \%$ & & $0.00 \%$ & $50.00 \%$ \\
\hline male & $50.00 \%$ & & $0.00 \%$ & & $100.00 \%$ & $50.00 \%$ \\
\hline Not applicable & $29.73 \%$ & $16.67 \%$ & $0.00 \%$ & $100.00 \%$ & $32.35 \%$ & $32.48 \%$ \\
\hline female & $63.64 \%$ & $0.00 \%$ & & $33.33 \%$ & $31.82 \%$ & $37.25 \%$ \\
\hline male & $36.36 \%$ & $100.00 \%$ & & $66.67 \%$ & $68.18 \%$ & $62.75 \%$ \\
\hline Grand Total & $100.00 \%$ & $100.00 \%$ & $100.00 \%$ & $100.00 \%$ & $100.00 \%$ & $100.00 \%$ \\
\hline
\end{tabular}

Table A3.20: Suggested changes in financial products and services to facilitate nutrient management technologies and practices, disaggregated by gender

\begin{tabular}{|c|c|c|c|c|c|c|}
\hline Changes & East Africa & India & $\begin{array}{l}\mathrm{L} \\
\text { America }\end{array}$ & SE Asia & $\begin{array}{l}\text { West } \\
\text { Africa }\end{array}$ & $\begin{array}{l}\text { Grand } \\
\text { Total }\end{array}$ \\
\hline Lower interest rates & $22.73 \%$ & $0.00 \%$ & $23.53 \%$ & $0.00 \%$ & $10.61 \%$ & $13.13 \%$ \\
\hline female & $40.00 \%$ & & $75.00 \%$ & & $42.86 \%$ & $47.62 \%$ \\
\hline male & $60.00 \%$ & & $25.00 \%$ & & $57.14 \%$ & $52.38 \%$ \\
\hline None & $0.00 \%$ & $44.44 \%$ & $11.76 \%$ & $0.00 \%$ & $18.18 \%$ & $13.75 \%$ \\
\hline female & & $25.00 \%$ & $100.00 \%$ & & $41.67 \%$ & $40.91 \%$ \\
\hline male & & $75.00 \%$ & $0.00 \%$ & & $58.33 \%$ & $59.09 \%$ \\
\hline Other & $4.55 \%$ & $0.00 \%$ & $0.00 \%$ & $0.00 \%$ & $1.52 \%$ & $1.88 \%$ \\
\hline female & $50.00 \%$ & & & & $100.00 \%$ & $66.67 \%$ \\
\hline male & $50.00 \%$ & & & & $0.00 \%$ & $33.33 \%$ \\
\hline Soft loans & $6.82 \%$ & $5.56 \%$ & $5.88 \%$ & $0.00 \%$ & $4.55 \%$ & $5.00 \%$ \\
\hline female & $33.33 \%$ & $100.00 \%$ & $100.00 \%$ & & $66.67 \%$ & $62.50 \%$ \\
\hline male & $66.67 \%$ & $0.00 \%$ & $0.00 \%$ & & $33.33 \%$ & $37.50 \%$ \\
\hline $\begin{array}{l}\text { Specific funds for adaptation to cli } \\
\text { change }\end{array}$ & $0.00 \%$ & $0.00 \%$ & $41.18 \%$ & $0.00 \%$ & $0.00 \%$ & $4.38 \%$ \\
\hline female & & & $71.43 \%$ & & & $71.43 \%$ \\
\hline male & & & $28.57 \%$ & & & $28.57 \%$ \\
\hline Subsidies with suppliers of inputs & $0.00 \%$ & $0.00 \%$ & $5.88 \%$ & $0.00 \%$ & $3.03 \%$ & $1.88 \%$ \\
\hline female & & & $100.00 \%$ & & $0.00 \%$ & $33.33 \%$ \\
\hline male & & & $0.00 \%$ & & $100.00 \%$ & $66.67 \%$ \\
\hline Subsidy on Fertilizers and Manure & $9.09 \%$ & $0.00 \%$ & $11.76 \%$ & $0.00 \%$ & $12.12 \%$ & $8.75 \%$ \\
\hline female & $75.00 \%$ & & $100.00 \%$ & & $75.00 \%$ & $78.57 \%$ \\
\hline male & $25.00 \%$ & & $0.00 \%$ & & $25.00 \%$ & $21.43 \%$ \\
\hline Training & $27.27 \%$ & $0.00 \%$ & $0.00 \%$ & $0.00 \%$ & $1.52 \%$ & $8.13 \%$ \\
\hline female & $41.67 \%$ & & & & $100.00 \%$ & $46.15 \%$ \\
\hline male & $58.33 \%$ & & & & $0.00 \%$ & $53.85 \%$ \\
\hline Not applicable & $29.55 \%$ & $50.00 \%$ & $0.00 \%$ & $100.00 \%$ & $48.48 \%$ & $43.13 \%$ \\
\hline female & $61.54 \%$ & $11.11 \%$ & & $33.33 \%$ & $31.25 \%$ & $34.78 \%$ \\
\hline male & $38.46 \%$ & $88.89 \%$ & & $66.67 \%$ & $68.75 \%$ & $65.22 \%$ \\
\hline Grand Total & $100.00 \%$ & $100.00 \%$ & $100.00 \%$ & $100.00 \%$ & $100.00 \%$ & $100.00 \%$ \\
\hline
\end{tabular}


Other climate smart technologies or practices applied

Table A3.21: Other climate smart technologies or practices applied, disaggregated by gender

\begin{tabular}{|c|c|c|c|c|c|c|}
\hline Technologies \& practices & East Africa & India & $\begin{array}{l}\mathbf{L} \\
\text { America }\end{array}$ & SE Asia & $\begin{array}{l}\text { West } \\
\text { Africa }\end{array}$ & $\begin{array}{l}\text { Grand } \\
\text { Total }\end{array}$ \\
\hline Agroforestry & $17.50 \%$ & $5.56 \%$ & $0.00 \%$ & $0.00 \%$ & $8.99 \%$ & $8.21 \%$ \\
\hline female & $28.57 \%$ & $0.00 \%$ & & & $12.50 \%$ & $18.75 \%$ \\
\hline male & $71.43 \%$ & $100.00 \%$ & & & $87.50 \%$ & $81.25 \%$ \\
\hline Animal rearing & $17.50 \%$ & $0.00 \%$ & $0.00 \%$ & $0.00 \%$ & $20.22 \%$ & $12.82 \%$ \\
\hline female & $85.71 \%$ & & & & $66.67 \%$ & $72.00 \%$ \\
\hline male & $14.29 \%$ & & & & $33.33 \%$ & $28.00 \%$ \\
\hline Cherry tomato varieties & $0.00 \%$ & $0.00 \%$ & $12.12 \%$ & $0.00 \%$ & $0.00 \%$ & $2.05 \%$ \\
\hline female & & & $100.00 \%$ & & & $100.00 \%$ \\
\hline Fish farm/aquaculture & $0.00 \%$ & $0.00 \%$ & $3.03 \%$ & $100.00 \%$ & $0.00 \%$ & $8.21 \%$ \\
\hline female & & & $100.00 \%$ & $33.33 \%$ & & $37.50 \%$ \\
\hline male & & & $0.00 \%$ & $66.67 \%$ & & $62.50 \%$ \\
\hline Food safety home garden & $0.00 \%$ & $0.00 \%$ & $33.33 \%$ & $0.00 \%$ & $1.12 \%$ & $6.15 \%$ \\
\hline female & & & $81.82 \%$ & & $100.00 \%$ & $83.33 \%$ \\
\hline male & & & $18.18 \%$ & & $0.00 \%$ & $16.67 \%$ \\
\hline Livestock management & $10.00 \%$ & $0.00 \%$ & $0.00 \%$ & $0.00 \%$ & $0.00 \%$ & $2.05 \%$ \\
\hline female & $50.00 \%$ & & & & & $50.00 \%$ \\
\hline male & $50.00 \%$ & & & & & $50.00 \%$ \\
\hline None & $0.00 \%$ & $72.22 \%$ & $3.03 \%$ & $0.00 \%$ & $2.25 \%$ & $8.21 \%$ \\
\hline female & & $30.77 \%$ & $100.00 \%$ & & $50.00 \%$ & $37.50 \%$ \\
\hline male & & $69.23 \%$ & $0.00 \%$ & & $50.00 \%$ & $62.50 \%$ \\
\hline Other & $20.00 \%$ & $0.00 \%$ & $3.03 \%$ & $0.00 \%$ & $4.49 \%$ & $6.67 \%$ \\
\hline female & $62.50 \%$ & & $100.00 \%$ & & $50.00 \%$ & $61.54 \%$ \\
\hline male & $37.50 \%$ & & $0.00 \%$ & & $50.00 \%$ & $38.46 \%$ \\
\hline Poultry keeping & $0.00 \%$ & $0.00 \%$ & $0.00 \%$ & $0.00 \%$ & $5.62 \%$ & $2.56 \%$ \\
\hline female & & & & & $80.00 \%$ & $80.00 \%$ \\
\hline male & & & & & $20.00 \%$ & $20.00 \%$ \\
\hline Tree Planting & $5.00 \%$ & $0.00 \%$ & $0.00 \%$ & $0.00 \%$ & $28.09 \%$ & $13.85 \%$ \\
\hline female & $100.00 \%$ & & & & $48.00 \%$ & $51.85 \%$ \\
\hline male & $0.00 \%$ & & & & $52.00 \%$ & $48.15 \%$ \\
\hline Varieties of drought resistant crops & $0.00 \%$ & $0.00 \%$ & $30.30 \%$ & $0.00 \%$ & $0.00 \%$ & $5.13 \%$ \\
\hline female & & & $80.00 \%$ & & & $80.00 \%$ \\
\hline male & & & $20.00 \%$ & & & $20.00 \%$ \\
\hline Wind break trees & $0.00 \%$ & $0.00 \%$ & $15.15 \%$ & $0.00 \%$ & $0.00 \%$ & $2.56 \%$ \\
\hline female & & & $80.00 \%$ & & & $80.00 \%$ \\
\hline male & & & $20.00 \%$ & & & $20.00 \%$ \\
\hline Not applicable & $30.00 \%$ & $22.22 \%$ & $0.00 \%$ & $0.00 \%$ & $29.21 \%$ & $21.54 \%$ \\
\hline female & $50.00 \%$ & $0.00 \%$ & & & $38.46 \%$ & $38.10 \%$ \\
\hline male & $50.00 \%$ & $100.00 \%$ & & & $61.54 \%$ & $61.90 \%$ \\
\hline Grand Total & $100.00 \%$ & $100.00 \%$ & $100.00 \%$ & $100.00 \%$ & $100.00 \%$ & $100.00 \%$ \\
\hline
\end{tabular}


Table A3.22: Investment amount (\$) in other CSA technologies and practices in the past year, disaggregated by gender

\begin{tabular}{|c|c|c|c|c|c|c|}
\hline Amount (\$) & East Africa & India & L America & SE Asia & West Africa & Grand Total \\
\hline 0 & $0.00 \%$ & $0.00 \%$ & $42.86 \%$ & $0.00 \%$ & $37.88 \%$ & $20.95 \%$ \\
\hline female & & & $83.33 \%$ & & $36.00 \%$ & $45.16 \%$ \\
\hline male & & & $16.67 \%$ & & $64.00 \%$ & $54.84 \%$ \\
\hline $0-50$ & $42.86 \%$ & $0.00 \%$ & $0.00 \%$ & $0.00 \%$ & $31.82 \%$ & $24.32 \%$ \\
\hline female & $66.67 \%$ & & & & $52.38 \%$ & $58.33 \%$ \\
\hline male & $33.33 \%$ & & & & $47.62 \%$ & $41.67 \%$ \\
\hline $50-100$ & $5.71 \%$ & $0.00 \%$ & $7.14 \%$ & $0.00 \%$ & $3.03 \%$ & $3.38 \%$ \\
\hline female & $100.00 \%$ & & $0.00 \%$ & & $100.00 \%$ & $80.00 \%$ \\
\hline male & $0.00 \%$ & & $100.00 \%$ & & $0.00 \%$ & $20.00 \%$ \\
\hline $100-500$ & $5.71 \%$ & $5.56 \%$ & $21.43 \%$ & $6.67 \%$ & $4.55 \%$ & $6.76 \%$ \\
\hline female & $100.00 \%$ & $0.00 \%$ & $100.00 \%$ & $0.00 \%$ & $0.00 \%$ & $50.00 \%$ \\
\hline male & $0.00 \%$ & $100.00 \%$ & $0.00 \%$ & $100.00 \%$ & $100.00 \%$ & $50.00 \%$ \\
\hline $500-1000$ & $0.00 \%$ & $0.00 \%$ & $14.29 \%$ & $33.33 \%$ & $0.00 \%$ & $4.73 \%$ \\
\hline female & & & $100.00 \%$ & $40.00 \%$ & & $57.14 \%$ \\
\hline male & & & $0.00 \%$ & $60.00 \%$ & & $42.86 \%$ \\
\hline$>1000$ & $0.00 \%$ & $0.00 \%$ & $0.00 \%$ & $60.00 \%$ & $0.00 \%$ & $6.08 \%$ \\
\hline female & & & & $33.33 \%$ & & $33.33 \%$ \\
\hline male & & & & $66.67 \%$ & & $66.67 \%$ \\
\hline Not Applicable & $45.71 \%$ & $94.44 \%$ & $14.29 \%$ & $0.00 \%$ & $22.73 \%$ & $33.78 \%$ \\
\hline female & $31.25 \%$ & $23.53 \%$ & $100.00 \%$ & & $40.00 \%$ & $34.00 \%$ \\
\hline male & $68.75 \%$ & $76.47 \%$ & $0.00 \%$ & & $60.00 \%$ & $66.00 \%$ \\
\hline Grand Total & $100.00 \%$ & $100.00 \%$ & $100.00 \%$ & $100.00 \%$ & $100.00 \%$ & $100.00 \%$ \\
\hline
\end{tabular}

Table A3.23: Sources of finance used to invest in other CSA technologies and practices in the past year, disaggregated by gender

\begin{tabular}{|c|c|c|c|c|c|c|}
\hline Sources & East Africa & India & L America & SE Asia & West Africa & Grand Total \\
\hline Bank & $0.00 \%$ & $0.00 \%$ & $0.00 \%$ & $33.33 \%$ & $0.00 \%$ & $3.87 \%$ \\
\hline female & & & & $14.29 \%$ & & $14.29 \%$ \\
\hline male & & & & $85.71 \%$ & & $85.71 \%$ \\
\hline CCAFS-Ecohabitats project & $0.00 \%$ & $0.00 \%$ & $52.17 \%$ & $0.00 \%$ & $0.00 \%$ & $6.63 \%$ \\
\hline female & & & $83.33 \%$ & & & $83.33 \%$ \\
\hline male & & & $16.67 \%$ & & & $16.67 \%$ \\
\hline Cooperative & $2.44 \%$ & $0.00 \%$ & $0.00 \%$ & $0.00 \%$ & $1.28 \%$ & $1.10 \%$ \\
\hline female & $100.00 \%$ & & & & $0.00 \%$ & $50.00 \%$ \\
\hline male & $0.00 \%$ & & & & $100.00 \%$ & $50.00 \%$ \\
\hline Input supplier & $4.88 \%$ & $0.00 \%$ & $0.00 \%$ & $0.00 \%$ & $2.56 \%$ & $2.21 \%$ \\
\hline female & $0.00 \%$ & & & & $50.00 \%$ & $25.00 \%$ \\
\hline male & $100.00 \%$ & & & & $50.00 \%$ & $75.00 \%$ \\
\hline Merry-go-round & $26.83 \%$ & $0.00 \%$ & $4.35 \%$ & $23.81 \%$ & $3.85 \%$ & $11.05 \%$ \\
\hline female & $90.91 \%$ & & $100.00 \%$ & $40.00 \%$ & $66.67 \%$ & $75.00 \%$ \\
\hline male & $9.09 \%$ & & $0.00 \%$ & $60.00 \%$ & $33.33 \%$ & $25.00 \%$ \\
\hline Microfinance institution & $2.44 \%$ & $0.00 \%$ & $0.00 \%$ & $0.00 \%$ & $1.28 \%$ & $1.10 \%$ \\
\hline female & $100.00 \%$ & & & & $100.00 \%$ & $100.00 \%$ \\
\hline Other & $0.00 \%$ & $0.00 \%$ & $21.74 \%$ & $4.76 \%$ & $6.41 \%$ & $6.08 \%$ \\
\hline female & & & $80.00 \%$ & $0.00 \%$ & $60.00 \%$ & $63.64 \%$ \\
\hline
\end{tabular}




\begin{tabular}{|c|c|c|c|c|c|c|}
\hline male & & & $20.00 \%$ & $100.00 \%$ & $40.00 \%$ & $36.36 \%$ \\
\hline Remittances funds & $4.88 \%$ & $0.00 \%$ & $0.00 \%$ & $0.00 \%$ & $2.56 \%$ & $2.21 \%$ \\
\hline female & $100.00 \%$ & & & & $50.00 \%$ & $75.00 \%$ \\
\hline male & $0.00 \%$ & & & & $50.00 \%$ & $25.00 \%$ \\
\hline SACCO & $9.76 \%$ & $0.00 \%$ & $0.00 \%$ & $0.00 \%$ & $1.28 \%$ & $2.76 \%$ \\
\hline female & $75.00 \%$ & & & & $100.00 \%$ & $80.00 \%$ \\
\hline male & $25.00 \%$ & & & & $0.00 \%$ & $20.00 \%$ \\
\hline Sale of farm products & $0.00 \%$ & $0.00 \%$ & $13.04 \%$ & $4.76 \%$ & $0.00 \%$ & $2.21 \%$ \\
\hline female & & & $100.00 \%$ & $100.00 \%$ & & $100.00 \%$ \\
\hline Savings collectors & $0.00 \%$ & $0.00 \%$ & $0.00 \%$ & $0.00 \%$ & $3.85 \%$ & $1.66 \%$ \\
\hline female & & & & & $66.67 \%$ & $66.67 \%$ \\
\hline male & & & & & $33.33 \%$ & $33.33 \%$ \\
\hline Self- financed & $7.32 \%$ & $5.56 \%$ & $4.35 \%$ & $28.57 \%$ & $15.38 \%$ & $12.71 \%$ \\
\hline female & $33.33 \%$ & $0.00 \%$ & $100.00 \%$ & $66.67 \%$ & $50.00 \%$ & $52.17 \%$ \\
\hline male & $66.67 \%$ & $100.00 \%$ & $0.00 \%$ & $33.33 \%$ & $50.00 \%$ & $47.83 \%$ \\
\hline Trader & $4.88 \%$ & $0.00 \%$ & $0.00 \%$ & $0.00 \%$ & $3.85 \%$ & $2.76 \%$ \\
\hline female & $0.00 \%$ & & & & $66.67 \%$ & $40.00 \%$ \\
\hline male & $100.00 \%$ & & & & $33.33 \%$ & $60.00 \%$ \\
\hline VSLA & $0.00 \%$ & $0.00 \%$ & $0.00 \%$ & $0.00 \%$ & $7.69 \%$ & $3.31 \%$ \\
\hline female & & & & & $50.00 \%$ & $50.00 \%$ \\
\hline male & & & & & $50.00 \%$ & $50.00 \%$ \\
\hline Not Applicable & $36.59 \%$ & $94.44 \%$ & $4.35 \%$ & $4.76 \%$ & $50.00 \%$ & $40.33 \%$ \\
\hline female & $33.33 \%$ & $23.53 \%$ & $100.00 \%$ & $0.00 \%$ & $33.33 \%$ & $31.51 \%$ \\
\hline male & $66.67 \%$ & $76.47 \%$ & $0.00 \%$ & $100.00 \%$ & $66.67 \%$ & $68.49 \%$ \\
\hline Grand Total & $100.00 \%$ & $100.00 \%$ & $100.00 \%$ & $100.00 \%$ & $100.00 \%$ & $100.00 \%$ \\
\hline
\end{tabular}

Table A3.24: Risks in other CSA technologies and practices, disaggregated by gender

\begin{tabular}{|c|c|c|c|c|c|c|}
\hline Risks & East Africa & India & $\begin{array}{l}\text { L } \\
\text { America }\end{array}$ & SE Asia & $\begin{array}{l}\text { West } \\
\text { Africa }\end{array}$ & $\begin{array}{l}\text { Grand } \\
\text { Total }\end{array}$ \\
\hline Animal grazing & $0.00 \%$ & $0.00 \%$ & $5.26 \%$ & $0.00 \%$ & $5.13 \%$ & $2.69 \%$ \\
\hline female & & & $100.00 \%$ & & $50.00 \%$ & $60.00 \%$ \\
\hline male & & & $0.00 \%$ & & $50.00 \%$ & $40.00 \%$ \\
\hline Bush fire & $0.00 \%$ & $0.00 \%$ & $0.00 \%$ & $0.00 \%$ & $6.41 \%$ & $2.69 \%$ \\
\hline female & & & & & $100.00 \%$ & $100.00 \%$ \\
\hline Cattle theft & $3.92 \%$ & $0.00 \%$ & $0.00 \%$ & $0.00 \%$ & $1.28 \%$ & $1.61 \%$ \\
\hline female & $100.00 \%$ & & & & $0.00 \%$ & $66.67 \%$ \\
\hline male & $0.00 \%$ & & & & $100.00 \%$ & $33.33 \%$ \\
\hline Damage from wind and rain & $7.84 \%$ & $0.00 \%$ & $21.05 \%$ & $5.00 \%$ & $3.85 \%$ & $6.45 \%$ \\
\hline female & $100.00 \%$ & & $100.00 \%$ & $0.00 \%$ & $66.67 \%$ & $83.33 \%$ \\
\hline male & $0.00 \%$ & & $0.00 \%$ & $100.00 \%$ & $33.33 \%$ & $16.67 \%$ \\
\hline Fear of reptile bite & $0.00 \%$ & $0.00 \%$ & $0.00 \%$ & $0.00 \%$ & $2.56 \%$ & $1.08 \%$ \\
\hline female & & & & & $100.00 \%$ & $100.00 \%$ \\
\hline Lack of forage accessibility & $3.92 \%$ & $0.00 \%$ & $0.00 \%$ & $5.00 \%$ & $1.28 \%$ & $2.15 \%$ \\
\hline female & $100.00 \%$ & & & $0.00 \%$ & $0.00 \%$ & $50.00 \%$ \\
\hline male & $0.00 \%$ & & & $100.00 \%$ & $100.00 \%$ & $50.00 \%$ \\
\hline Lack of Technical know how & $0.00 \%$ & $0.00 \%$ & $0.00 \%$ & $0.00 \%$ & $2.56 \%$ & $1.08 \%$ \\
\hline female & & & & & $50.00 \%$ & $50.00 \%$ \\
\hline male & & & & & $50.00 \%$ & $50.00 \%$ \\
\hline None & $0.00 \%$ & $5.56 \%$ & $10.53 \%$ & $0.00 \%$ & $12.82 \%$ & $6.99 \%$ \\
\hline female & & $0.00 \%$ & $50.00 \%$ & & $40.00 \%$ & $38.46 \%$ \\
\hline male & & $100.00 \%$ & $50.00 \%$ & & $60.00 \%$ & $61.54 \%$ \\
\hline
\end{tabular}




\begin{tabular}{|c|c|c|c|c|c|c|}
\hline Not enough (stored) water & $21.57 \%$ & $0.00 \%$ & $21.05 \%$ & $5.00 \%$ & $14.10 \%$ & $14.52 \%$ \\
\hline female & $81.82 \%$ & & $100.00 \%$ & $0.00 \%$ & $45.45 \%$ & $66.67 \%$ \\
\hline male & $18.18 \%$ & & $0.00 \%$ & $100.00 \%$ & $54.55 \%$ & $33.33 \%$ \\
\hline Pest and Diseases kills our animals & $21.57 \%$ & $0.00 \%$ & $0.00 \%$ & $0.00 \%$ & $5.13 \%$ & $8.06 \%$ \\
\hline female & $72.73 \%$ & & & & $25.00 \%$ & $60.00 \%$ \\
\hline male & $27.27 \%$ & & & & $75.00 \%$ & $40.00 \%$ \\
\hline Plagues and diseases & $3.92 \%$ & $0.00 \%$ & $26.32 \%$ & $0.00 \%$ & $2.56 \%$ & $4.84 \%$ \\
\hline female & $100.00 \%$ & & $80.00 \%$ & & $100.00 \%$ & $88.89 \%$ \\
\hline male & $0.00 \%$ & & $20.00 \%$ & & $0.00 \%$ & $11.11 \%$ \\
\hline The use of traditional methods & $0.00 \%$ & $0.00 \%$ & $0.00 \%$ & $10.00 \%$ & $0.00 \%$ & $1.08 \%$ \\
\hline male & & & & $100.00 \%$ & & $100.00 \%$ \\
\hline Trader is set up the price & $0.00 \%$ & $0.00 \%$ & $0.00 \%$ & $10.00 \%$ & $0.00 \%$ & $1.08 \%$ \\
\hline male & & & & $100.00 \%$ & & $100.00 \%$ \\
\hline Unpredictable weather & $7.84 \%$ & $0.00 \%$ & $0.00 \%$ & $0.00 \%$ & $1.28 \%$ & $2.69 \%$ \\
\hline female & $75.00 \%$ & & & & $0.00 \%$ & $60.00 \%$ \\
\hline male & $25.00 \%$ & & & & $100.00 \%$ & $40.00 \%$ \\
\hline Water pollution & $0.00 \%$ & $0.00 \%$ & $0.00 \%$ & $60.00 \%$ & $0.00 \%$ & $6.45 \%$ \\
\hline female & & & & $33.33 \%$ & & $33.33 \%$ \\
\hline male & & & & $66.67 \%$ & & $66.67 \%$ \\
\hline Other & $1.96 \%$ & $0.00 \%$ & $10.53 \%$ & $5.00 \%$ & $1.28 \%$ & $2.69 \%$ \\
\hline female & $100.00 \%$ & & $100.00 \%$ & $100.00 \%$ & $0.00 \%$ & $80.00 \%$ \\
\hline male & $0.00 \%$ & & $0.00 \%$ & $0.00 \%$ & $100.00 \%$ & $20.00 \%$ \\
\hline Capital missing & $5.88 \%$ & $0.00 \%$ & $0.00 \%$ & $0.00 \%$ & $0.00 \%$ & $1.61 \%$ \\
\hline female & $33.33 \%$ & & & & & $33.33 \%$ \\
\hline male & $66.67 \%$ & & & & & $66.67 \%$ \\
\hline Not Applicable & $21.57 \%$ & $94.44 \%$ & $5.26 \%$ & $0.00 \%$ & $39.74 \%$ & $32.26 \%$ \\
\hline female & $27.27 \%$ & $23.53 \%$ & $100.00 \%$ & & $35.48 \%$ & $31.67 \%$ \\
\hline male & $72.73 \%$ & $76.47 \%$ & $0.00 \%$ & & $64.52 \%$ & $68.33 \%$ \\
\hline Grand Total & $100.00 \%$ & $100.00 \%$ & $100.00 \%$ & $100.00 \%$ & $100.00 \%$ & $100.00 \%$ \\
\hline
\end{tabular}

Table A3.25: Suggested changes to facilitate other CSA technologies and practices, disaggregated by gender

\begin{tabular}{|c|c|c|c|c|c|c|}
\hline Changes & East Africa & India & $\begin{array}{l}\mathrm{L} \\
\text { America }\end{array}$ & SE Asia & $\begin{array}{l}\text { West } \\
\text { Africa }\end{array}$ & $\begin{array}{l}\text { Grand } \\
\text { Total }\end{array}$ \\
\hline credit In-Kind & $2.50 \%$ & $0.00 \%$ & $5.00 \%$ & $5.56 \%$ & $4.23 \%$ & $3.59 \%$ \\
\hline female & $0.00 \%$ & & $100.00 \%$ & $100.00 \%$ & $100.00 \%$ & $83.33 \%$ \\
\hline male & $100.00 \%$ & & $0.00 \%$ & $0.00 \%$ & $0.00 \%$ & $16.67 \%$ \\
\hline Higher loans needed & $0.00 \%$ & $0.00 \%$ & $0.00 \%$ & $50.00 \%$ & $0.00 \%$ & $5.39 \%$ \\
\hline female & & & & $11.11 \%$ & & $11.11 \%$ \\
\hline male & & & & $88.89 \%$ & & $88.89 \%$ \\
\hline Lower interest & $2.50 \%$ & $0.00 \%$ & $15.00 \%$ & $5.56 \%$ & $5.63 \%$ & $5.39 \%$ \\
\hline female & $100.00 \%$ & & $66.67 \%$ & $0.00 \%$ & $0.00 \%$ & $33.33 \%$ \\
\hline male & $0.00 \%$ & & $33.33 \%$ & $100.00 \%$ & $100.00 \%$ & $66.67 \%$ \\
\hline None & $0.00 \%$ & $0.00 \%$ & $20.00 \%$ & $22.22 \%$ & $8.45 \%$ & $8.38 \%$ \\
\hline female & & & $100.00 \%$ & $50.00 \%$ & $33.33 \%$ & $57.14 \%$ \\
\hline male & & & $0.00 \%$ & $50.00 \%$ & $66.67 \%$ & $42.86 \%$ \\
\hline Other & $17.50 \%$ & $0.00 \%$ & $0.00 \%$ & $0.00 \%$ & $9.86 \%$ & $8.38 \%$ \\
\hline female & $85.71 \%$ & & & & $57.14 \%$ & $71.43 \%$ \\
\hline male & $14.29 \%$ & & & & $42.86 \%$ & $28.57 \%$ \\
\hline Soft loans & $12.50 \%$ & $0.00 \%$ & $20.00 \%$ & $5.56 \%$ & $5.63 \%$ & $8.38 \%$ \\
\hline
\end{tabular}




\begin{tabular}{|c|c|c|c|c|c|c|}
\hline female & $80.00 \%$ & & $75.00 \%$ & $0.00 \%$ & $0.00 \%$ & $50.00 \%$ \\
\hline male & $20.00 \%$ & & $25.00 \%$ & $100.00 \%$ & $100.00 \%$ & $50.00 \%$ \\
\hline Subsidy & $10.00 \%$ & $0.00 \%$ & $10.00 \%$ & $0.00 \%$ & $1.41 \%$ & $4.19 \%$ \\
\hline female & $50.00 \%$ & & $100.00 \%$ & & $100.00 \%$ & $71.43 \%$ \\
\hline male & $50.00 \%$ & & $0.00 \%$ & & $0.00 \%$ & $28.57 \%$ \\
\hline Subsidy for adaptation measures & $0.00 \%$ & $0.00 \%$ & $20.00 \%$ & $0.00 \%$ & $0.00 \%$ & $2.40 \%$ \\
\hline female & & & $50.00 \%$ & & & $50.00 \%$ \\
\hline male & & & $50.00 \%$ & & & $50.00 \%$ \\
\hline Training & $27.50 \%$ & $0.00 \%$ & $5.00 \%$ & $5.56 \%$ & $9.86 \%$ & $11.98 \%$ \\
\hline female & $45.45 \%$ & & $100.00 \%$ & $0.00 \%$ & $42.86 \%$ & $45.00 \%$ \\
\hline male & $54.55 \%$ & & $0.00 \%$ & $100.00 \%$ & $57.14 \%$ & $55.00 \%$ \\
\hline Not Applicable & $27.50 \%$ & $100.00 \%$ & $5.00 \%$ & $5.56 \%$ & $54.93 \%$ & $41.92 \%$ \\
\hline female & $36.36 \%$ & $22.22 \%$ & $100.00 \%$ & $100.00 \%$ & $43.59 \%$ & $38.57 \%$ \\
\hline male & $63.64 \%$ & $77.78 \%$ & $0.00 \%$ & $0.00 \%$ & $56.41 \%$ & $61.43 \%$ \\
\hline Grand Total & $100.00 \%$ & $100.00 \%$ & $100.00 \%$ & $100.00 \%$ & $100.00 \%$ & $100.00 \%$ \\
\hline
\end{tabular}

Table A3.26: Percentage of respondents willing to invest more if additional access to loans or any other financial incentive, disaggregated by gender

\begin{tabular}{|c|c|c|c|c|c|c|}
\hline Willingness & East Africa & India & LAmerica & SE Asia & $\begin{array}{l}\text { West } \\
\text { Africa }\end{array}$ & $\begin{array}{l}\text { Grand } \\
\text { Total }\end{array}$ \\
\hline no & $2.86 \%$ & $5.56 \%$ & $0.00 \%$ & $26.67 \%$ & $0.00 \%$ & $4.05 \%$ \\
\hline female & $100.00 \%$ & $100.00 \%$ & & $50.00 \%$ & & $66.67 \%$ \\
\hline male & $0.00 \%$ & $0.00 \%$ & & $50.00 \%$ & & $33.33 \%$ \\
\hline yes & $88.57 \%$ & $77.78 \%$ & $100.00 \%$ & $73.33 \%$ & $92.42 \%$ & $88.51 \%$ \\
\hline female & $54.84 \%$ & $21.43 \%$ & $85.71 \%$ & $27.27 \%$ & $40.98 \%$ & $45.80 \%$ \\
\hline male & $45.16 \%$ & $78.57 \%$ & $14.29 \%$ & $72.73 \%$ & $59.02 \%$ & $54.20 \%$ \\
\hline Not applicable & $8.57 \%$ & $16.67 \%$ & $0.00 \%$ & $0.00 \%$ & $7.58 \%$ & $7.43 \%$ \\
\hline female & $33.33 \%$ & $0.00 \%$ & & & $60.00 \%$ & $36.36 \%$ \\
\hline male & $66.67 \%$ & $100.00 \%$ & & & $40.00 \%$ & $63.64 \%$ \\
\hline Grand Total & $100.00 \%$ & $100.00 \%$ & $100.00 \%$ & $100.00 \%$ & $100.00 \%$ & $100.00 \%$ \\
\hline
\end{tabular}

Table A3.27: Percentage of respondents who received training(s)

\begin{tabular}{|c|c|c|c|c|c|c|}
\hline Type of training & East Africa & India & $\begin{array}{l}\text { L } \\
\text { America }\end{array}$ & SE Asia & $\begin{array}{l}\text { West } \\
\text { Africa }\end{array}$ & $\begin{array}{l}\text { Grand } \\
\text { Total }\end{array}$ \\
\hline agri-business development & $24.53 \%$ & $9.52 \%$ & $26.32 \%$ & $21.43 \%$ & $8.33 \%$ & $16.58 \%$ \\
\hline female & $46.15 \%$ & $0.00 \%$ & $80.00 \%$ & $33.33 \%$ & $83.33 \%$ & $53.13 \%$ \\
\hline male & $53.85 \%$ & $100.00 \%$ & $20.00 \%$ & $66.67 \%$ & $16.67 \%$ & $46.88 \%$ \\
\hline CSA technologies or practices & $49.06 \%$ & $47.62 \%$ & $73.68 \%$ & $53.57 \%$ & $75.00 \%$ & $61.66 \%$ \\
\hline female & $65.38 \%$ & $20.00 \%$ & $85.71 \%$ & $33.33 \%$ & $40.74 \%$ & $48.74 \%$ \\
\hline male & $34.62 \%$ & $80.00 \%$ & $14.29 \%$ & $66.67 \%$ & $59.26 \%$ & $51.26 \%$ \\
\hline use of financial products or services & $18.87 \%$ & $4.76 \%$ & $0.00 \%$ & $25.00 \%$ & $2.78 \%$ & $10.36 \%$ \\
\hline female & $60.00 \%$ & $0.00 \%$ & & $42.86 \%$ & $0.00 \%$ & $45.00 \%$ \\
\hline male & $40.00 \%$ & $100.00 \%$ & & $57.14 \%$ & $100.00 \%$ & $55.00 \%$ \\
\hline Not applicable & $7.55 \%$ & $38.10 \%$ & $0.00 \%$ & $0.00 \%$ & $13.89 \%$ & $11.40 \%$ \\
\hline female & $50.00 \%$ & $25.00 \%$ & & & $50.00 \%$ & $40.91 \%$ \\
\hline male & $50.00 \%$ & $75.00 \%$ & & & $50.00 \%$ & $59.09 \%$ \\
\hline Grand Total & $100.00 \%$ & $100.00 \%$ & $100.00 \%$ & $100.00 \%$ & $100.00 \%$ & $100.00 \%$ \\
\hline
\end{tabular}




\section{Annex 4 Questionnaire}

\begin{tabular}{|c|c|c|}
\hline$\underset{\text { CGIAR }}{\text { bj }}$ & $\begin{array}{l}\text { RestaRCH Program on } \\
\text { Climate Change, } \\
\text { Agriculture and } \\
\text { Food Security }\end{array}$ & $\begin{array}{l}\text { Questionnaire } \\
\text { 'Understanding the demand for financial } \\
\text { products and services in CSA' }\end{array}$ \\
\hline & 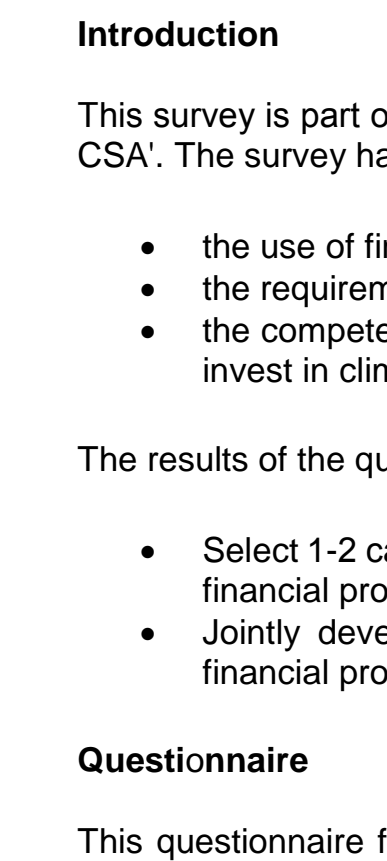 & $\begin{array}{l}\text { iness models, incentives and innovative finance for scaling } \\
\text { geningen University \& Research. It aims to understand: } \\
\text { ices by smallholder farmers and SMEs } \\
\text { s and SMEs for financial products and services } \\
\text { nable them to use these financial products and services to } \\
\text { o: } \\
\text { study factors, conditions and impact of 'packages' including } \\
\text { city building and climate smart business development } \\
\text { the requirements of smallholder farmers and SMEs for } \\
\text { est in CSA }\end{array}$ \\
\hline
\end{tabular}


have identified at an earlier stage. If more than two potential case studies per region have been identified, you are asked to focus on the two most promising ones. For each of the potential case studies, you are kindly requested to conduct 15 interviews. The data will be collected via the semi-structured questionnaire presented hereafter.

Depending the potential case study, respondents of the questionnaire will be:

- Female and male smallholder farmers. At least $50 \%$ of the respondents should be female farmers

- SMEs involved in different stages of the value chain (e.g. service providers, input suppliers). At least $25 \%$ of the respondents should be (women-led) SMEs.

Each interview should last no more than 45 minutes.

All answers to the questions are mandatory. If there is no answer possible, please fill out 'not applicable'.

\section{Helpdesk}

The questionnaire is a digital version. However, if preferred you can use a hard copy version in the field. Once the questionnaire has been completed, you can enter the data in the digital form. If you have any questions about the questionnaire, please do not hesitate to contact the helpdesk, Annemarie

\section{Deadline}

Mid March Start pre-testing (3 respondents)

\section{Monday 3 April Closure pre-testing}

Friday 14 April Implementation corrections in the digital system Receipt final version of questionnaire

Monday 15 May Submission results of the questionnaire through the digital system

\section{Sections}

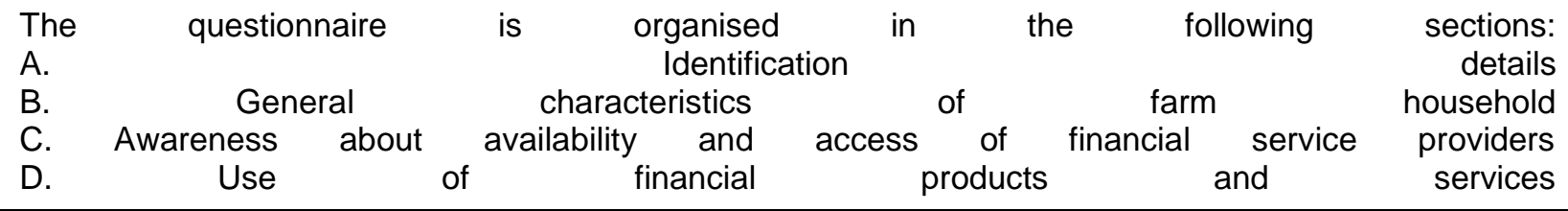




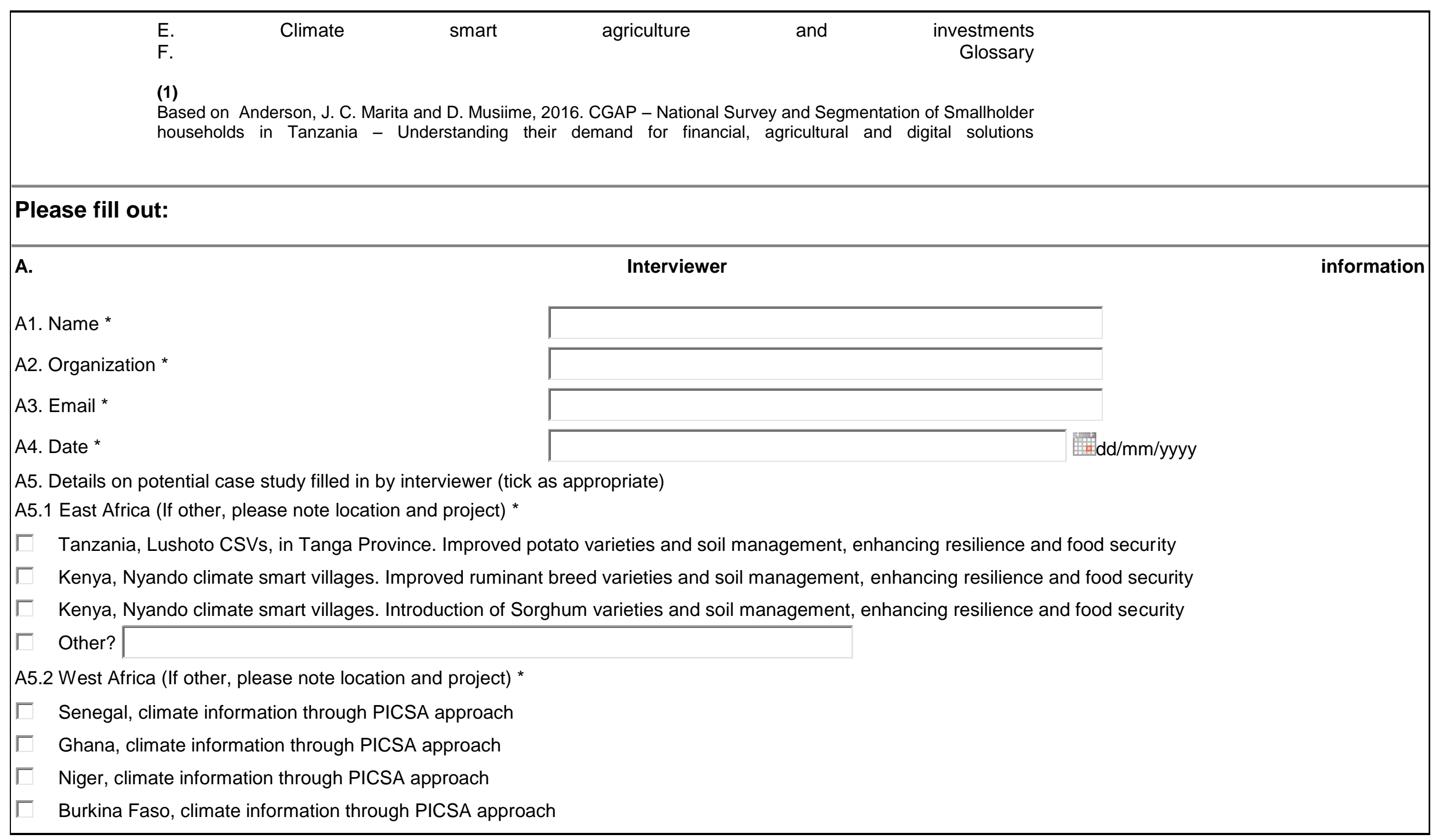


Г Ghana Northern, Agro-advisory and climate information, via ICT platform

$\Gamma \quad$ Other?

A5.3 Latin America (If other, please note location and project) *

$\ulcorner$ Colombia, Cauca CSV, municipality of Popayan. Pest resistant varieties and management

$\ulcorner$ Other?

A5.4 South Asia (If other, please note location and project) *

$\ulcorner\quad$ India: ICT and machinery provision

$\ulcorner$ Bangladesh: ICT and machinery provision

$\ulcorner$ Nepal: ICT and machinery provision

O Other?

A5.5 Southeast Asia (If other, please note location and project) *

$\ulcorner\quad$ Laos, Savannakhet Prov: drought and erratic start of the rainy season. Opportunity for new seed varieties and mechanisation

$\ulcorner\quad$ Vietnam, Bac Lieu Prov: drought and salinity intrusion. Opportunity for new seed varieties and mechanisation

$\ulcorner\quad$ Vietnam, Hoang Phong commune, Hoang Hoa District, Thanh Hoa province: Aquaculture farming for livelihoods and food security

ᄃ Laos, Samphan District, Mai District: Meteorological station providing weather information

$\ulcorner\quad$ Laos, My Loi CSV, Ha Tinh; Dien Bien, Dien Bien. Meteorological station providing weather information

$\ulcorner\quad$ Cambodia, Tra Hat village, Bac Lieu province. Pest resistant varieties and management

$\ulcorner\quad$ Cambodia, Ekxang village, Vientiane Province. Pest resistant varieties and management

$\ulcorner\quad$ Cambodia, Rohal Suong CSV, Battambong. Pest resistant varieties and management

O Other?

\section{Instructions for selection of interviewees:}

- Please chose 15 respondent per case study

- Respondents include female and male smallholder farmers. At least $50 \%$ of the respondents should be female farmers 
- SMEs involved in different stages of the value chain (e.g. service providers, input suppliers). At least $25 \%$ of the respondents should be (women-led) SMEs

Respondent identification details:

A6. Interview number *

A7. Name of respondent *

A8. Gender *

<please make a choice> $>$ Please make a choice (only

>>Please make a choice (only one answer possible):

male

female

A9. Age *

A10. Orientation/location *

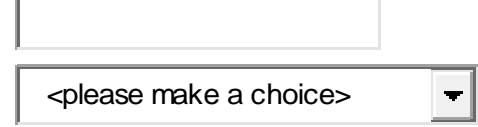

>>Please make a choice (only one answer possible):

rural

<make a choices $\quad+$

$>>$ Please fill in:

country

A12. State/province/region *

A13. District/county *

A14. Village/climate smart village *

A15. If applicable, name of SME *

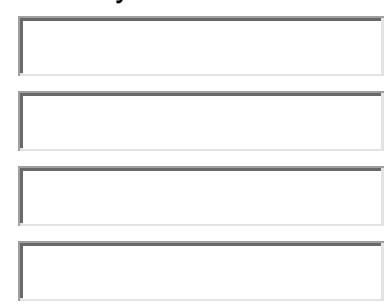

B.

General

characteristics

of

farm

household 
B1a. What is the gender of head of household? *

B1b. What is the age of head of household? *

B2. Number of people in your household *

B3. How many years have you been farming? *

B4. What is the highest education family/farm/company? *

Note: this question includes all family members

living/contributing to the household. E.g. if some member lives

abroad and sends money, should be included.

B5. What is the household's current financial status? *

>> Please make a choice (only one answer possible):

Not enough money for food

Enough money for food and clothes only

Enough money for food and clothes and can save a bit, but not enough to buy expensive goods Afford to buy certain expensive goods

Farm size and production:

(?)

Note: This refers to ALL farm production

B6. How many hectares (ha) of agricultural land do you cultivate? * 


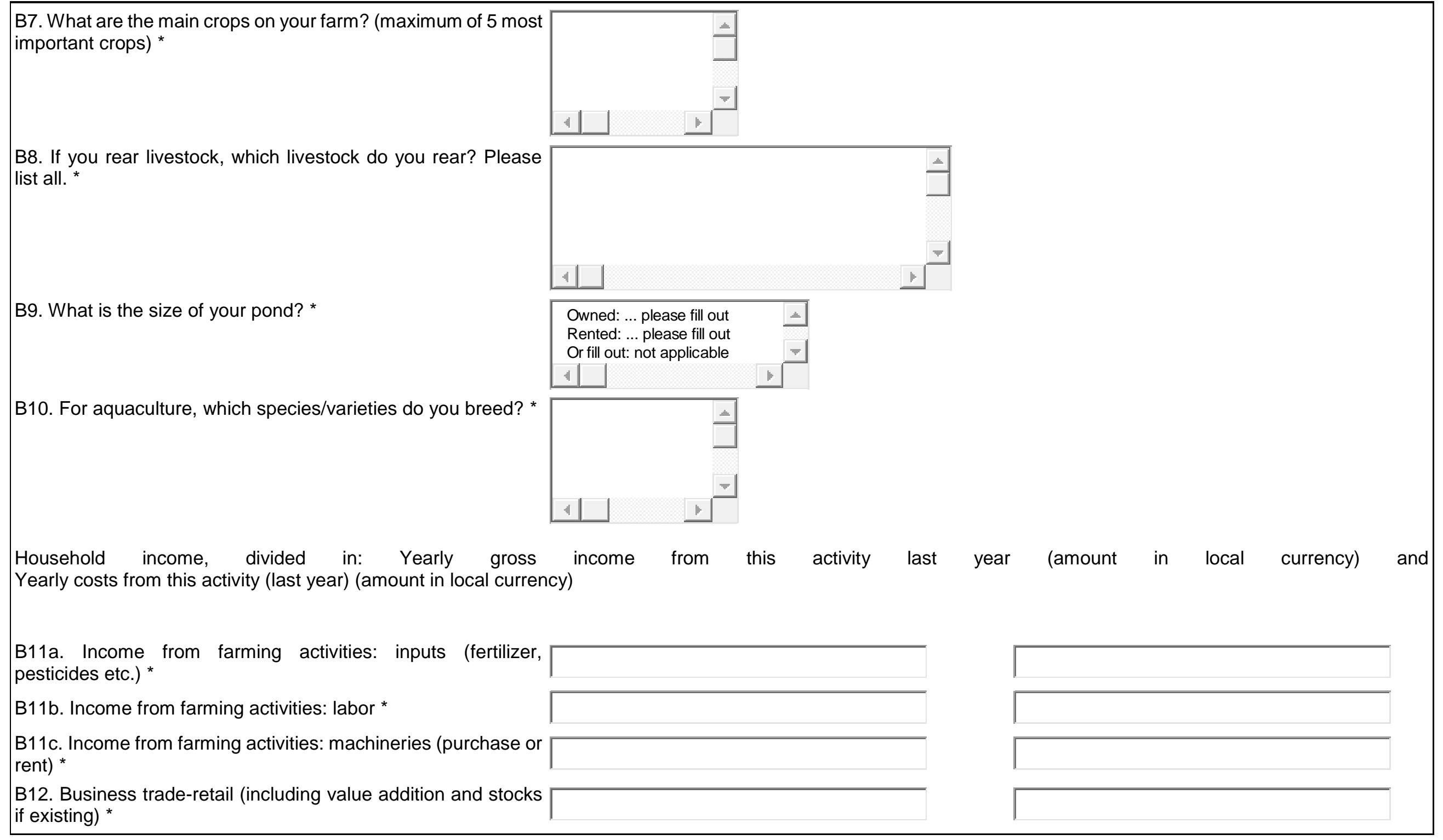




\section{B13. Paid labour on other farms *}

B14. Other business (retail, manufacturing, services) *

B15. Retirement *

B16. Remittances income *

B17. Income from other sources (please specify sources) *

c.

Awareness

about

availability

and

access

of

financial

service

providers

Availability of financial service providers: (Try to list ALL the sources that could be available to the respondent, and not only the sources that he/she actually uses)

C1. PAYMENTS: if you would like to send money to someone else who lives far away, where could you do that?

First column Name of institution, group or person (in case of person, fill out 'person', name is not necessary)

Second column Type or source (bank, MFI, SACCO, moneylender, susu, family/friends, mobile money, etc.; check both formal and informal!)

Name institution

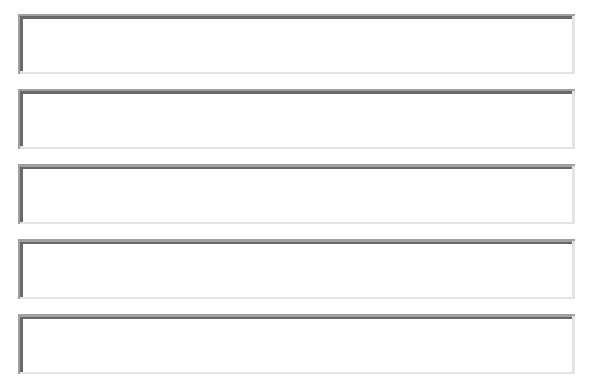

Type or source

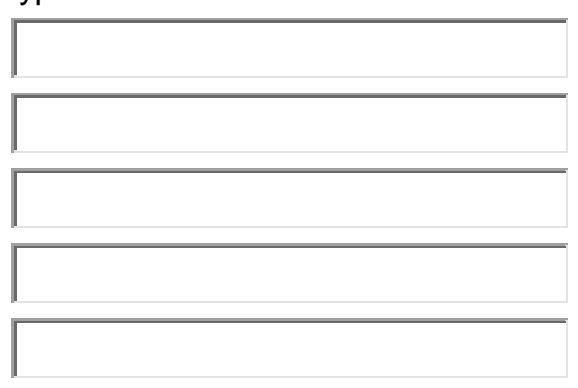

C2. SAVINGS: If you would like to deposit your savings in a safe place, where could you do that?

First column Name of institution, group or person (in case of person, fill out 'person', name is not necessary) 
Second column Type or source (bank, MFI, SACCO, moneylender, susu, family/friends, mobile money, etc.; check both formal and informal!)
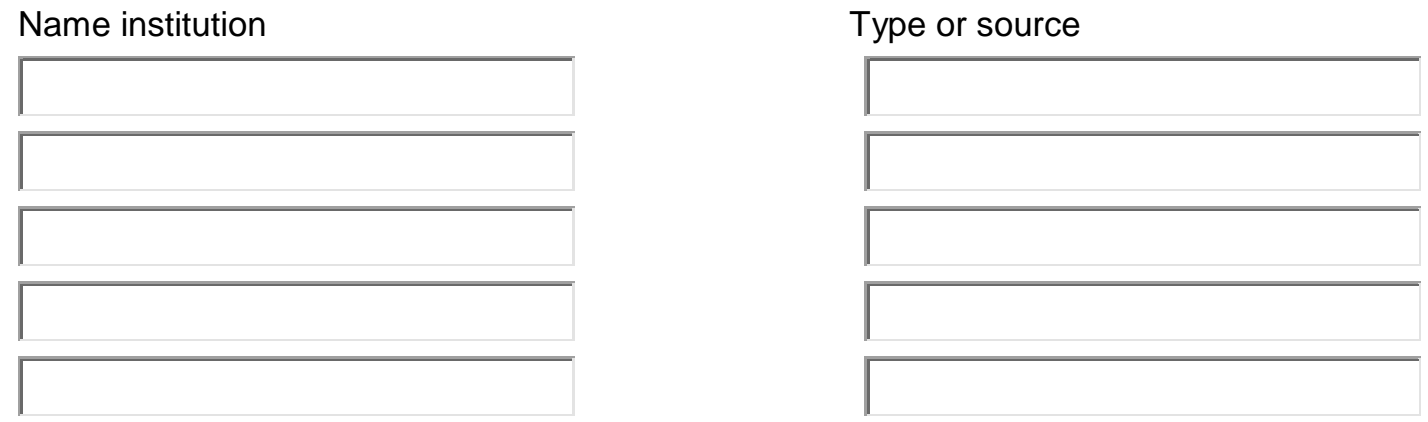

C3. CREDIT: If you would need to borrow money, for your family expenses or for your farm, what are the places where you could go?

First column Name of institution, group or person (in case of person, fill out 'person', name is not necessary)

Second column Type or source (bank, MFI, SACCO, moneylender, susu, family/friends, mobile money, etc.; check both formal and informal!)
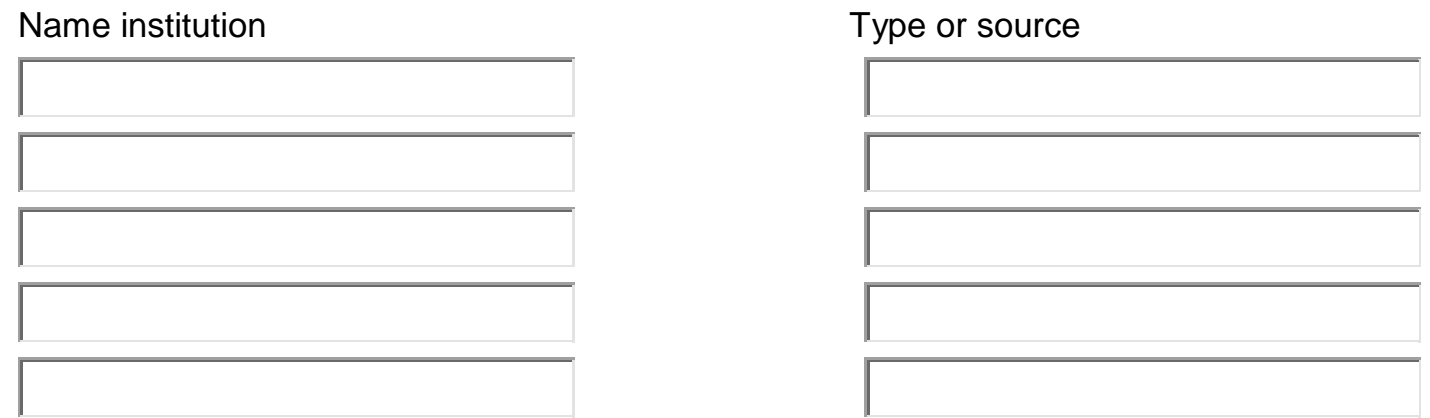

C4. INSURANCE: if you would like to have any type of insurance (for example health insurance or agricultural insurance), where could you get that?

First column Name of institution, group or person (in case of person, fill out 'person', name is not necessary) 
Second column Type or source (bank, MFI, SACCO, moneylender, susu, family/friends, mobile money, etc.; check both formal and informal!)

Name institution

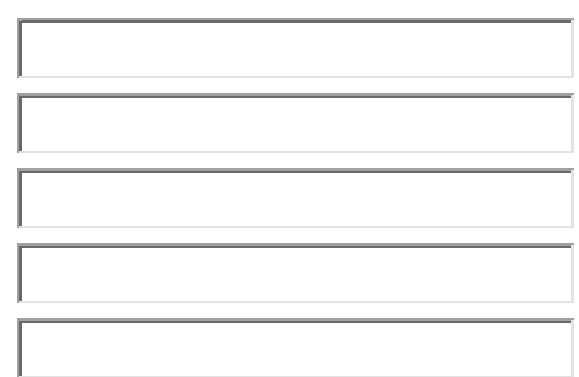

C5. What are your most important sources to improve $\Gamma$ Self-learning

knowledge on financial products and services? (3 most important) *

\author{
Г Facilitating agencies \\ Г Internet \\ $\ulcorner$ News, magazines, books \\ Г Trainings \\ Г Development partners \\ Г Government extension services \\ Г Farmers associations \\ Г SMS services \\ Г Radio \\ ГSchool \\ $\Gamma$ Spouse \\ - Friends/ family \\ Г Community members \\ Г Traders/ middlemen \\ Г Input supplier
}

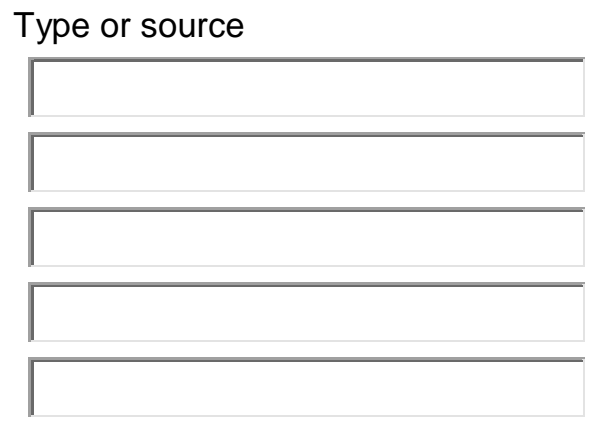




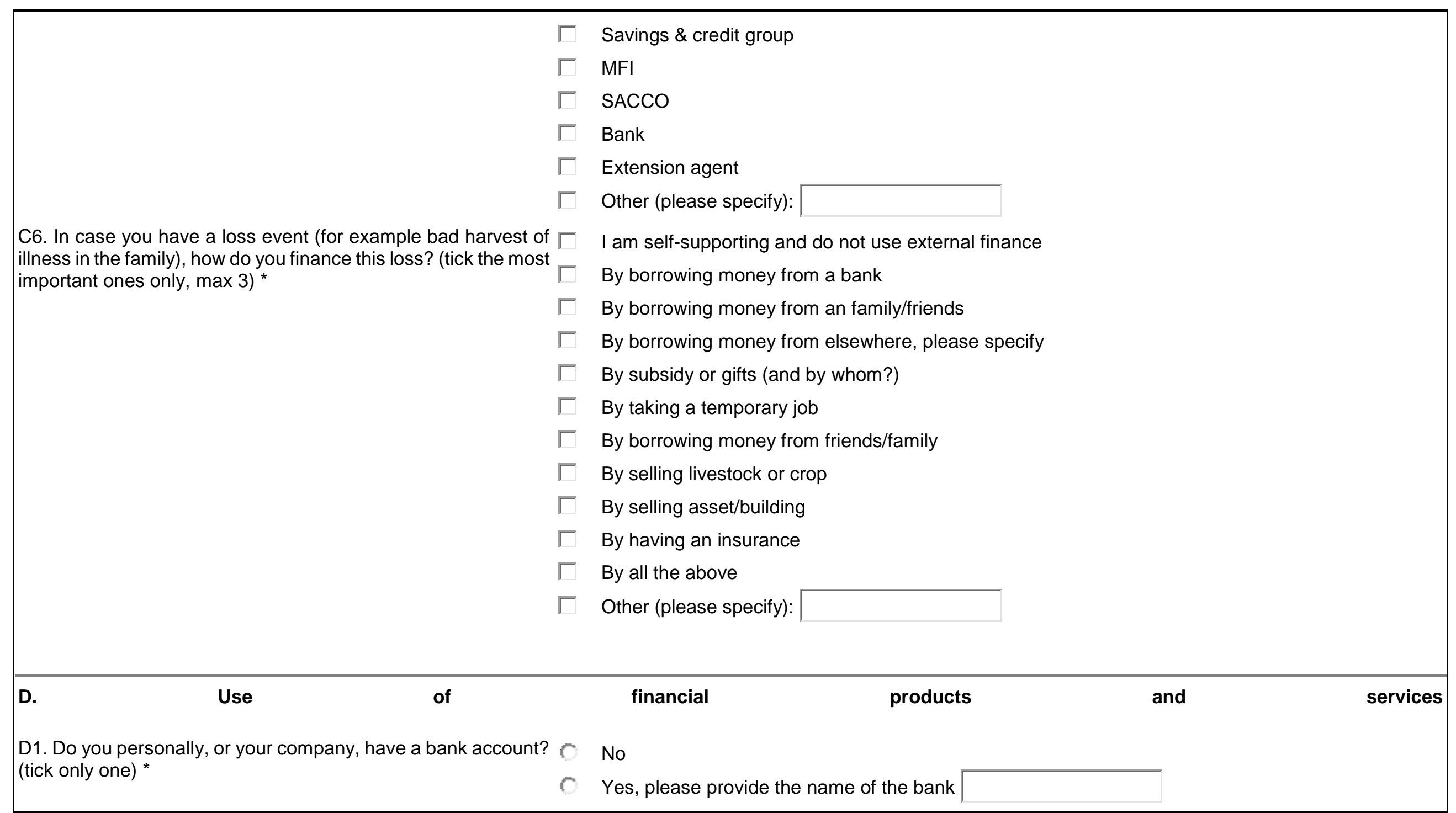




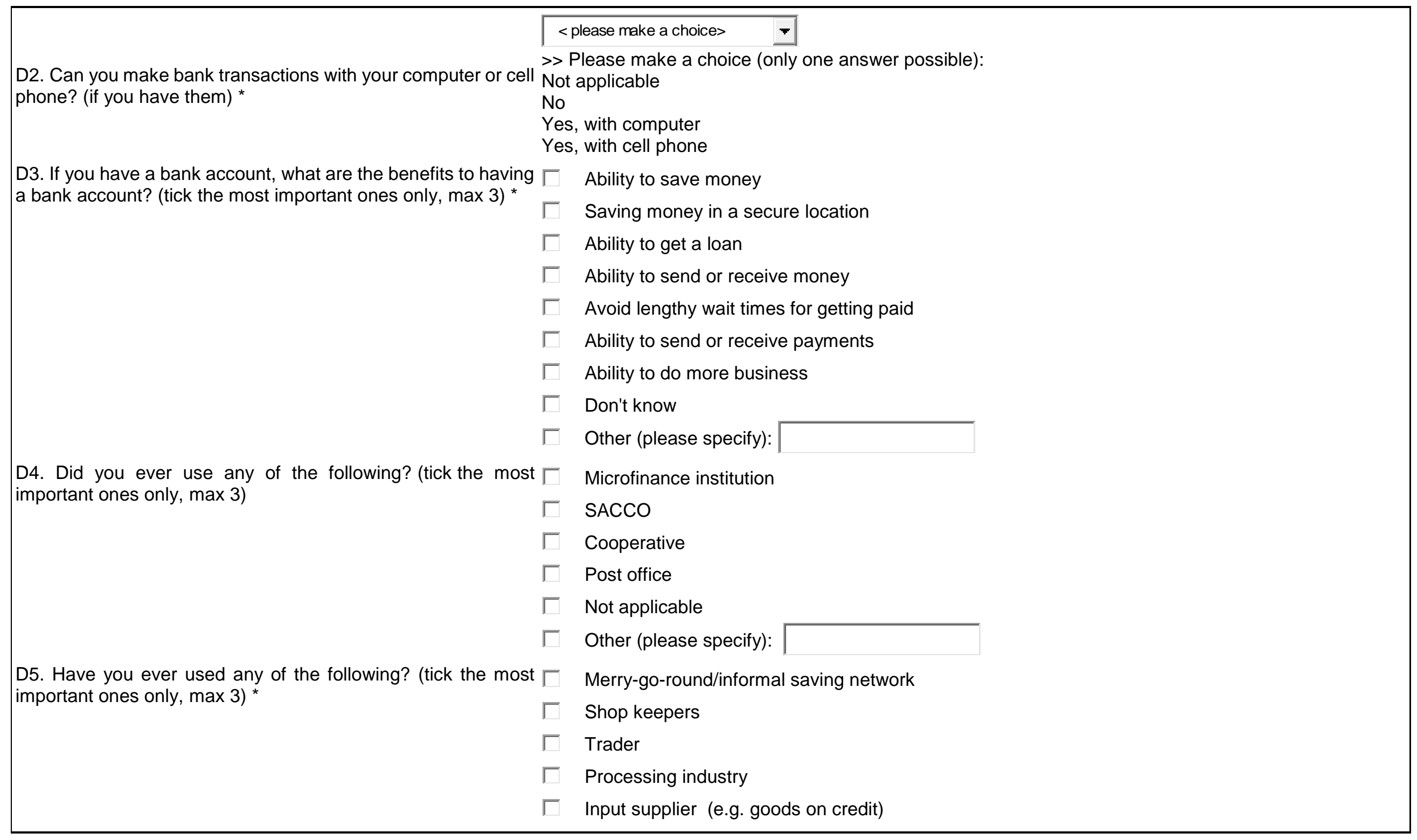




\begin{tabular}{|c|c|c|}
\hline & Г & $\begin{array}{l}\text { A money guard/someone in workplace or neighbourhood that collects and keeps savings (usually } \\
\text { someone closely related to the family) }\end{array}$ \\
\hline & Г & Savings collectors (not closely related to the family) \\
\hline & Г & Other groups \\
\hline & $\Gamma$ & A digital card or recharge card that is not attached to a bank or MFI account \\
\hline & $\Gamma$ & Vouchers \\
\hline & $\Gamma$ & Remittances funds \\
\hline & $\Gamma$ & Others (please specify): \\
\hline D6. If applicable, when was the last time you used these servic & es c & service providers for any financial activity (tick which applies) \\
\hline D6.1 Merry-go-round/informal saving network * & $\Gamma$ & Past 7 days \\
\hline & Г & Past 30 days \\
\hline & Г & More than 30 days ago \\
\hline & $\Gamma$ & Stopped using \\
\hline & $\Gamma$ & Don't know \\
\hline & Г & Not applicable \\
\hline D6.2 Shop keeper * & $\Gamma$ & Past 7 days \\
\hline & Г & Past 30 days \\
\hline & $\Gamma$ & More than 30 days ago \\
\hline & Г & Stopped using \\
\hline & $\Gamma$ & Don't know \\
\hline & $\Gamma$ & Not applicable \\
\hline D6.3 A money guard/someone in workplace or neighbourhood & 厂 & Past 7 days \\
\hline & $\Gamma$ & Past 30 days \\
\hline & Г & More than 30 days ago \\
\hline & Г & Stopped using \\
\hline
\end{tabular}




\begin{tabular}{|c|c|c|}
\hline & Г & Don't know \\
\hline & Г & Not applicable \\
\hline \multirow{11}{*}{$\begin{array}{l}\text { D7. What could be the reason why you borrow money? (tick the } \\
\text { most important ones only, max } 3)^{*}\end{array}$} & $\Gamma$ & To pay for school fees \\
\hline & $\Gamma$ & To pay for food \\
\hline & $\Gamma$ & To pay for other household/family expenditures \\
\hline & $\Gamma$ & To invest in (aquaculture) farm inputs (for example fingerlings and feed) \\
\hline & Г & To invest in equipment of my farm/company \\
\hline & $\Gamma$ & To build a factory, sheds etc. to grow my farm/company \\
\hline & Г & To renew equipment \\
\hline & $\Gamma$ & To hire (new) personnel \\
\hline & Г & To finance negative events not related to climate change \\
\hline & $\Gamma$ & To finance negative events related to climate change \\
\hline & Г & Other (please specify): \\
\hline \multirow{10}{*}{$\begin{array}{l}\text { D8. In the case of investments in your farm for inputs (for } \\
\text { example seed and fertilizer) how do you finance this } \\
\text { investment? (tick the most important ones only, max } 3)^{*}\end{array}$} & $\Gamma$ & I am self-supporting and do not use external finance \\
\hline & $\Gamma$ & By borrowing money from a bank \\
\hline & $\Gamma$ & By borrowing money from an family/friends \\
\hline & $\Gamma$ & By subsidy or gifts (and by whom?) \\
\hline & $\Gamma$ & By taking a temporary job \\
\hline & $\Gamma$ & By borrow money from friends/family \\
\hline & $\Gamma$ & By selling livestock, crop or aquaculture products \\
\hline & $\Gamma$ & By selling asset/building \\
\hline & $\Gamma$ & By having an Insurance \\
\hline & $\Gamma$ & By borrowing money from elsewhere (please specify): \\
\hline D9. Credit sources and allocation & & \\
\hline
\end{tabular}

$84 \mid$ Wageningen Environmental Research rapport XXXX 


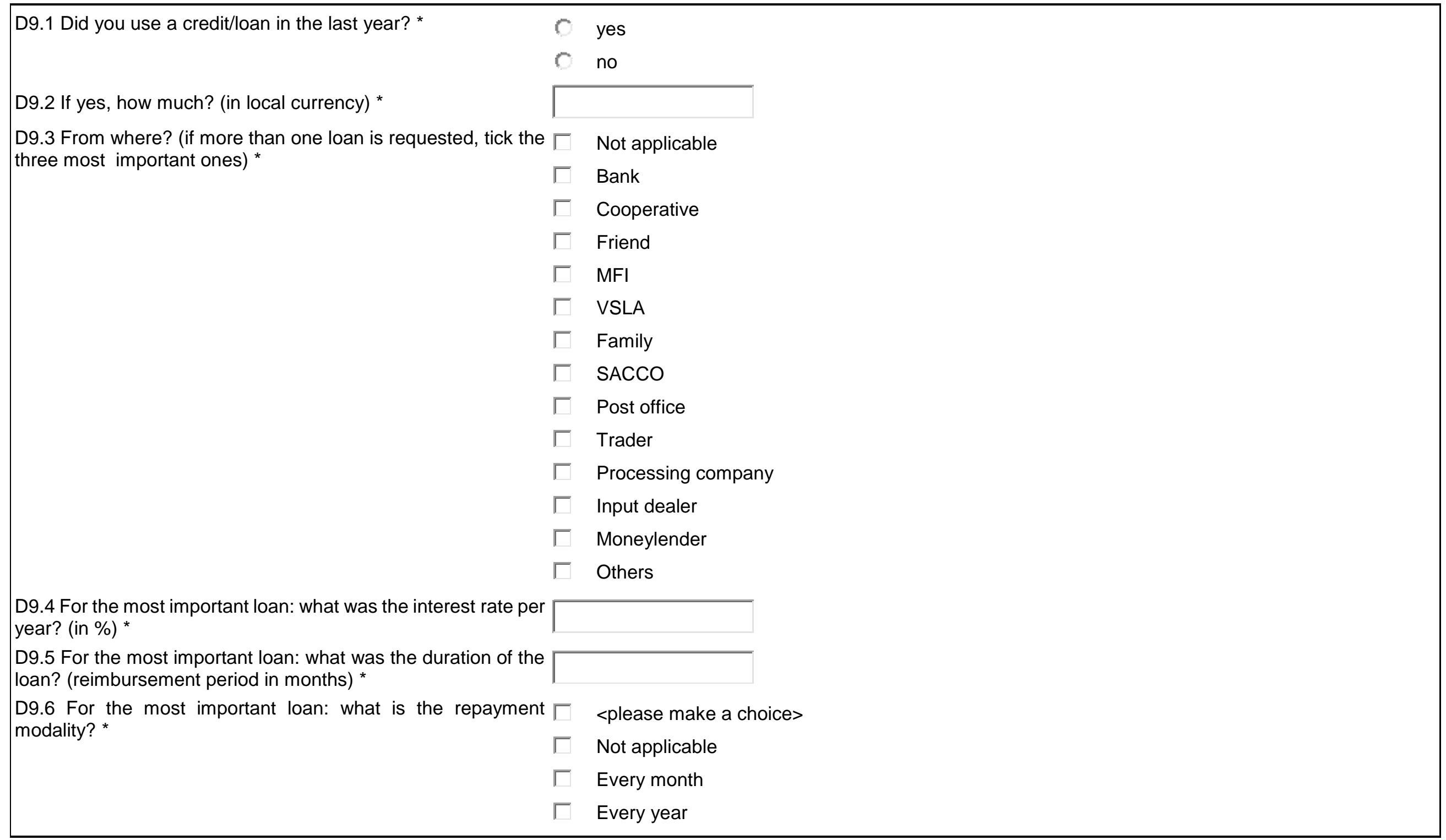




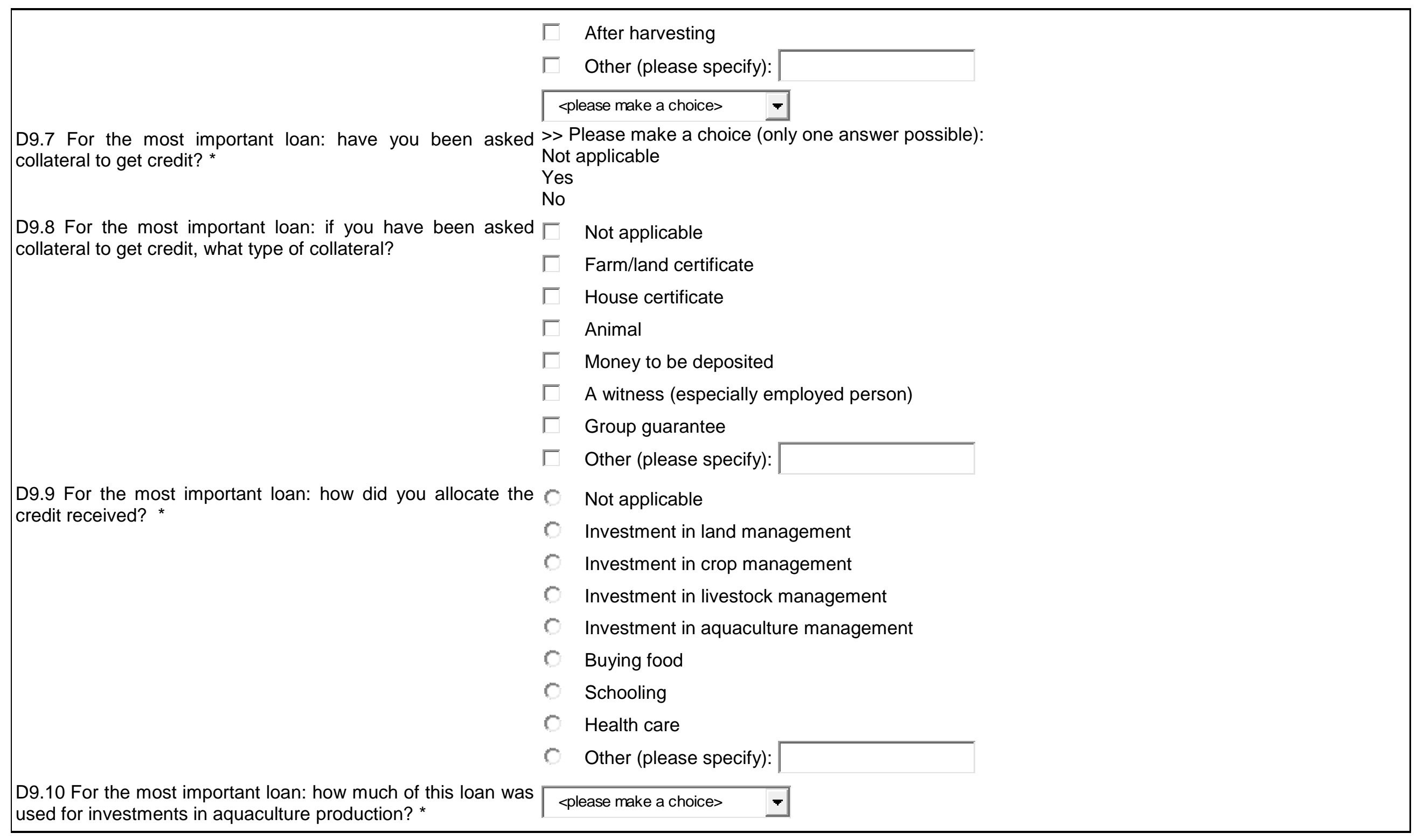




\begin{tabular}{|c|c|c|c|c|c|}
\hline \multirow{9}{*}{ D9.11 If applicable, why did you not ask for a credit? * } & \multicolumn{5}{|c|}{$\begin{array}{l}\text { > Please make a choice (only one answer possible): } \\
\text { Not applicable } \\
\text { Less than } 25 \% \\
\text { Between } 25 \text { and } 50 \% \\
\text { Between } 50 \text { and } 75 \% \\
\text { Between } 75 \% \text { and } 100 \%\end{array}$} \\
\hline & \multicolumn{5}{|c|}{ Not applicable } \\
\hline & \multicolumn{5}{|c|}{ Farming is very risky and banks have no confidence to farmers } \\
\hline & \multicolumn{5}{|c|}{ Lack of collateral } \\
\hline & \multicolumn{5}{|c|}{ Interest rate too high } \\
\hline & \multicolumn{5}{|c|}{ Procedures complicated } \\
\hline & \multicolumn{5}{|c|}{ Don't know procedures } \\
\hline & \multicolumn{5}{|c|}{ I'm so far from lenders } \\
\hline & \multicolumn{5}{|c|}{ Other (please specify): } \\
\hline Climate & smart & agriculture & and & & investments \\
\hline conservation & land & preparation & technologies & or & practices \\
\hline $\begin{array}{l}\text { E1.1 What, if any, soil conservation or land preparation } \\
\text { technologies or practices do you apply? } \\
\text { (?) } \\
\text { Fill out: Types of land preparation, technologies or practices or } \\
\text { not applicable }\end{array}$ & \multicolumn{5}{|c|}{$\begin{array}{ll} \pm \\
\square\end{array}$} \\
\hline $\begin{array}{l}\text { E1.2 How much did you invest in these soil conservation or land } \\
\text { preparation technologies } \\
\text { practices in the past year? (in local currency) * }\end{array}$ & & & & & \\
\hline
\end{tabular}




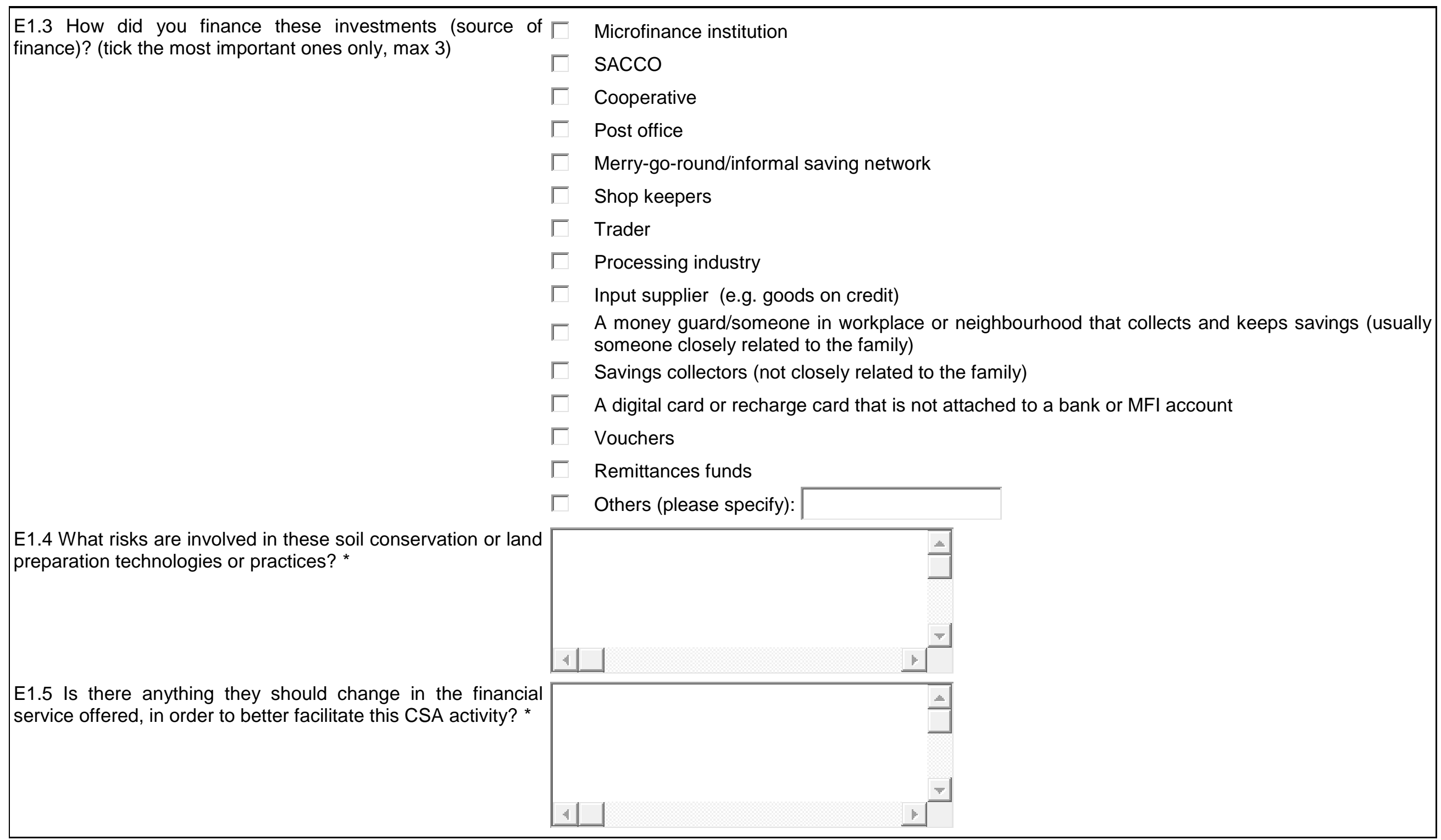




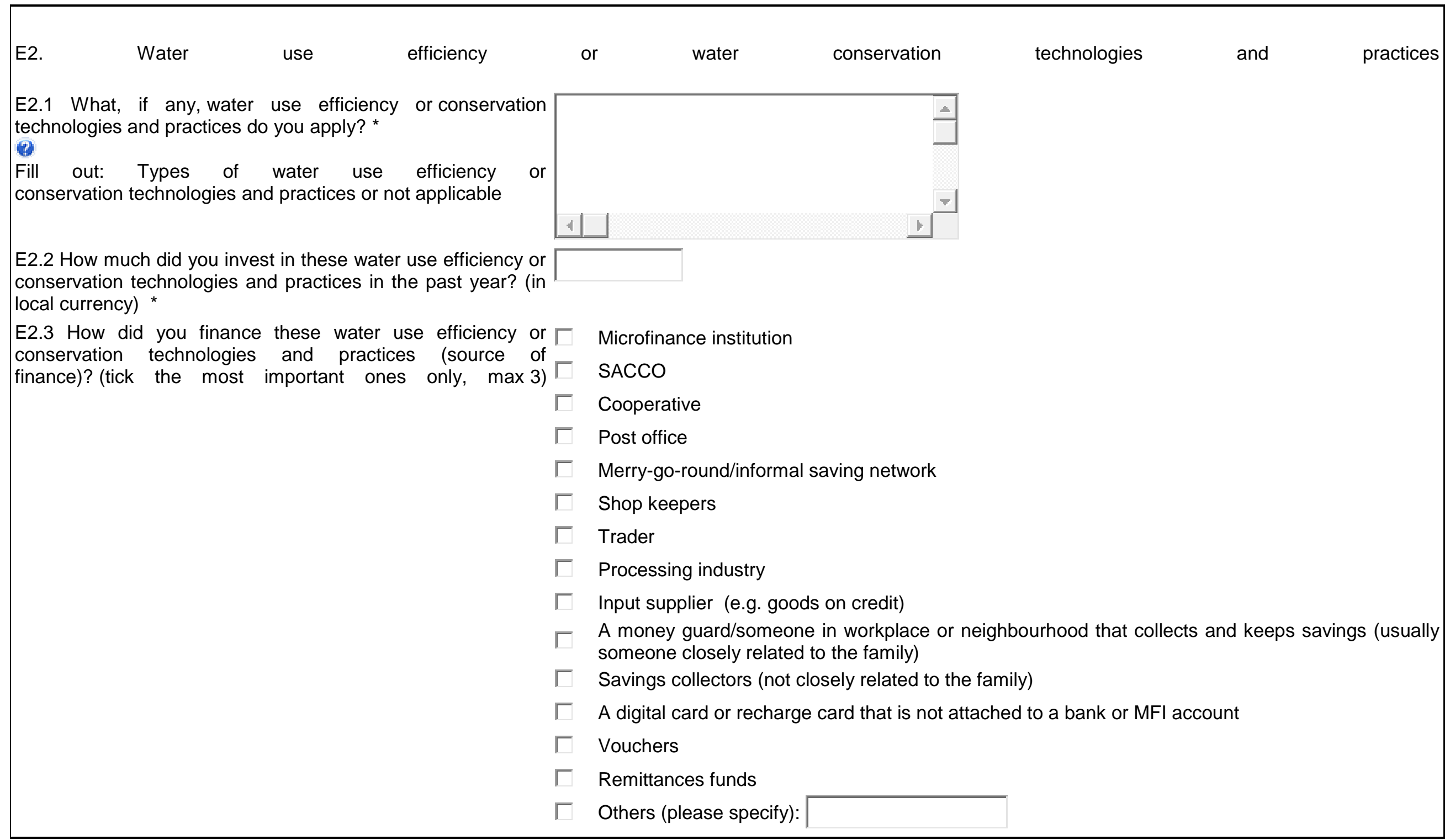




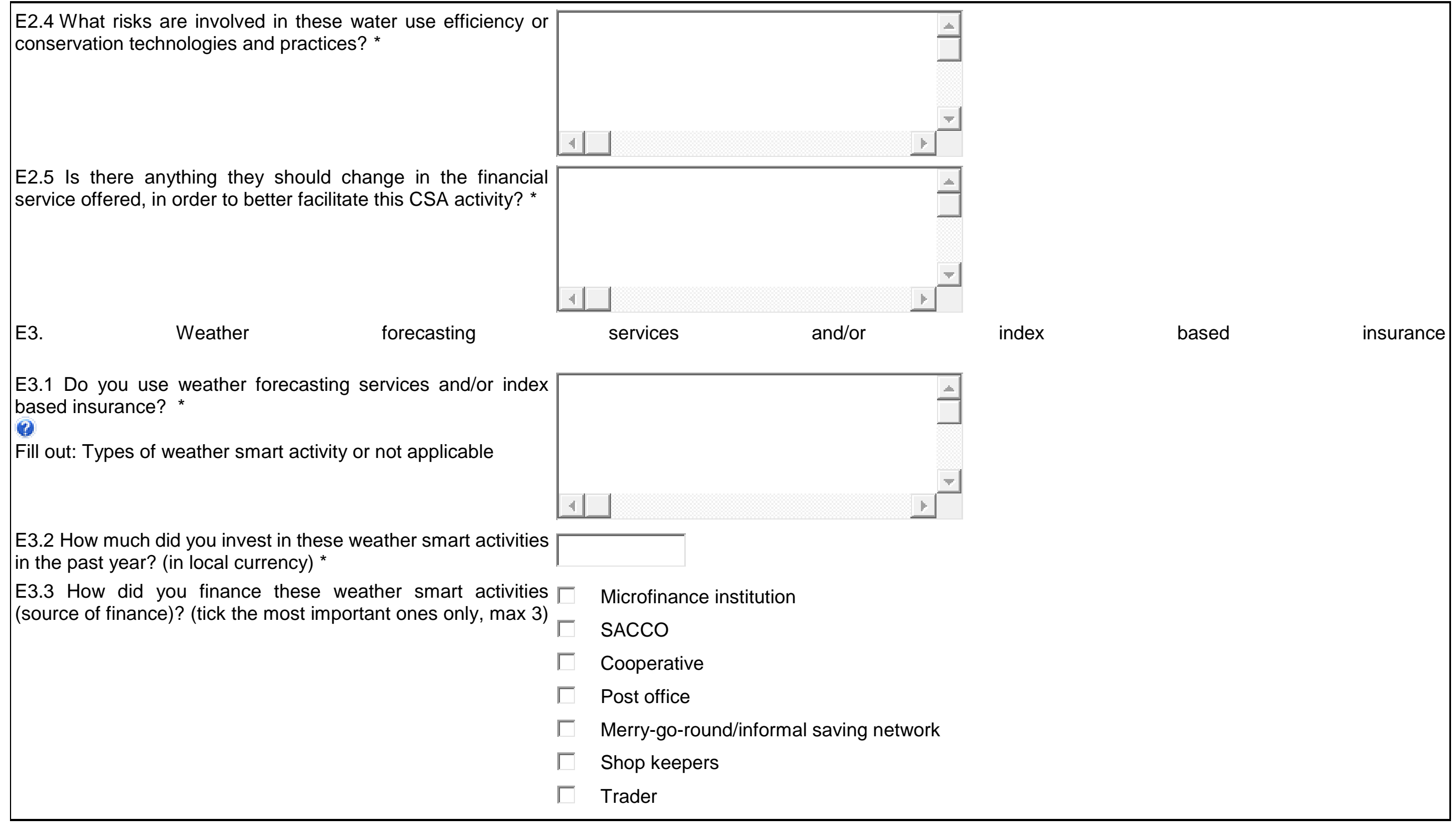




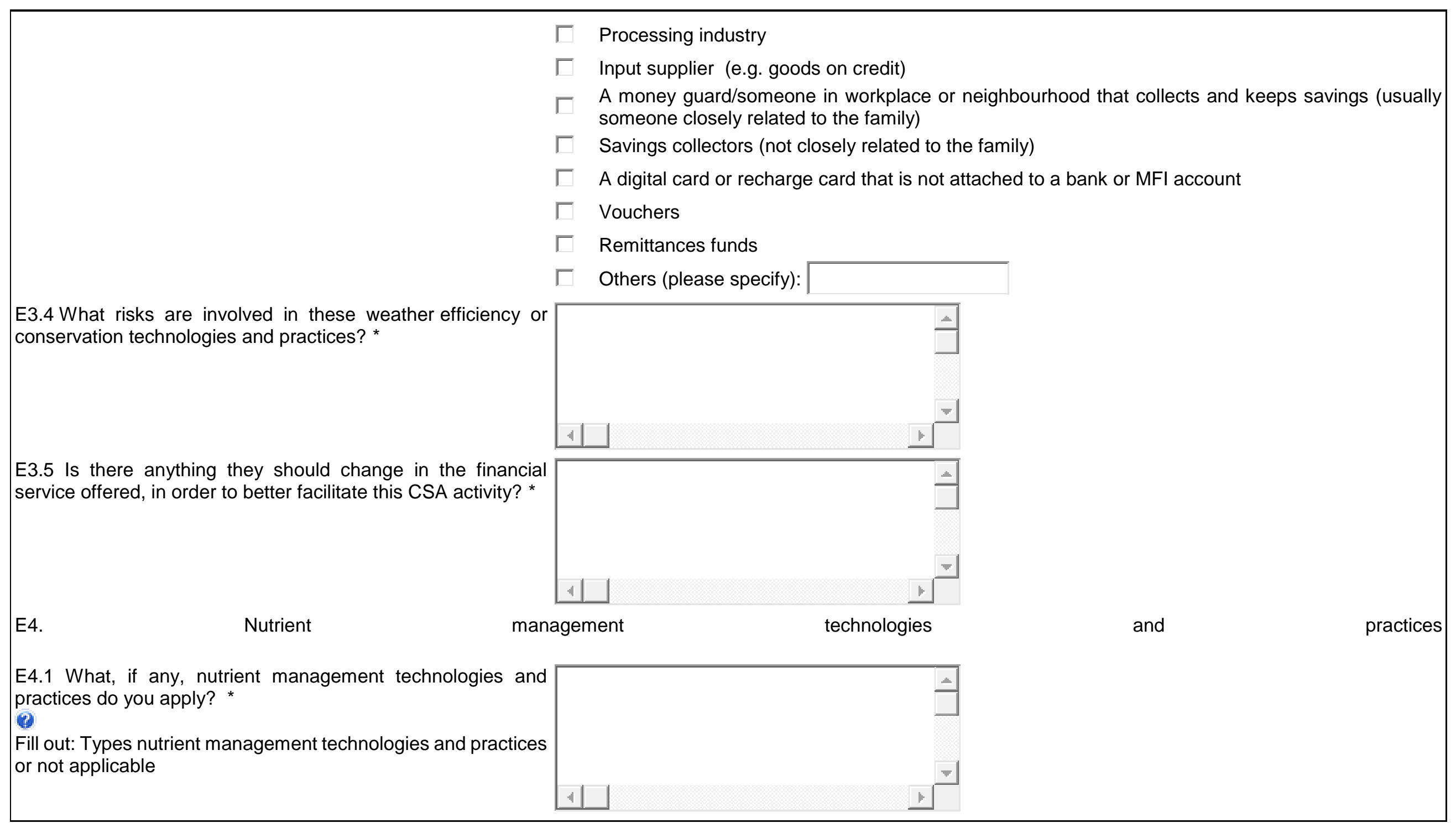




\section{E4.2 How much did you invest in these nutrient management}

technologies and practices in the past year? (in local currency)

E4.3 How did you finance these nutrient management technologies and practices (source of finance)? (tick the most important ones only,

$\max$

3)

Microfinance institution

Г SACCO

C Cooperative

$\Gamma$ Post office

$\ulcorner\quad$ Merry-go-round/informal saving network

$\ulcorner$ Shop keepers

$\Gamma \quad$ Trader

$\ulcorner$ Processing industry

$\ulcorner\quad$ Input supplier (e.g. goods on credit)

- A money guard/someone in workplace or neighbourhood that collects and keeps savings (usually someone closely related to the family)

$\ulcorner$ Savings collectors (not closely related to the family)

- A digital card or recharge card that is not attached to a bank or MFI account

$\Gamma$ Vouchers

$\Gamma$ Remittances funds

$\Gamma$ Others (please specify):

E4.4 What risks are involved in these nutrient management technologies? *

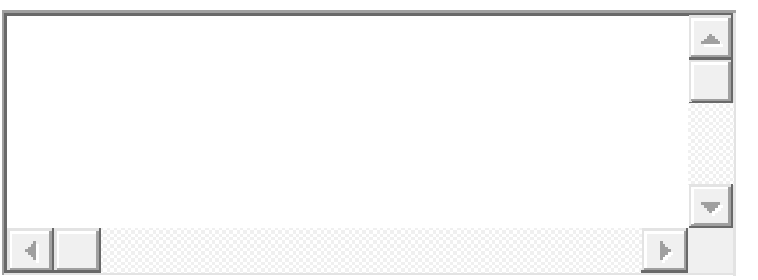




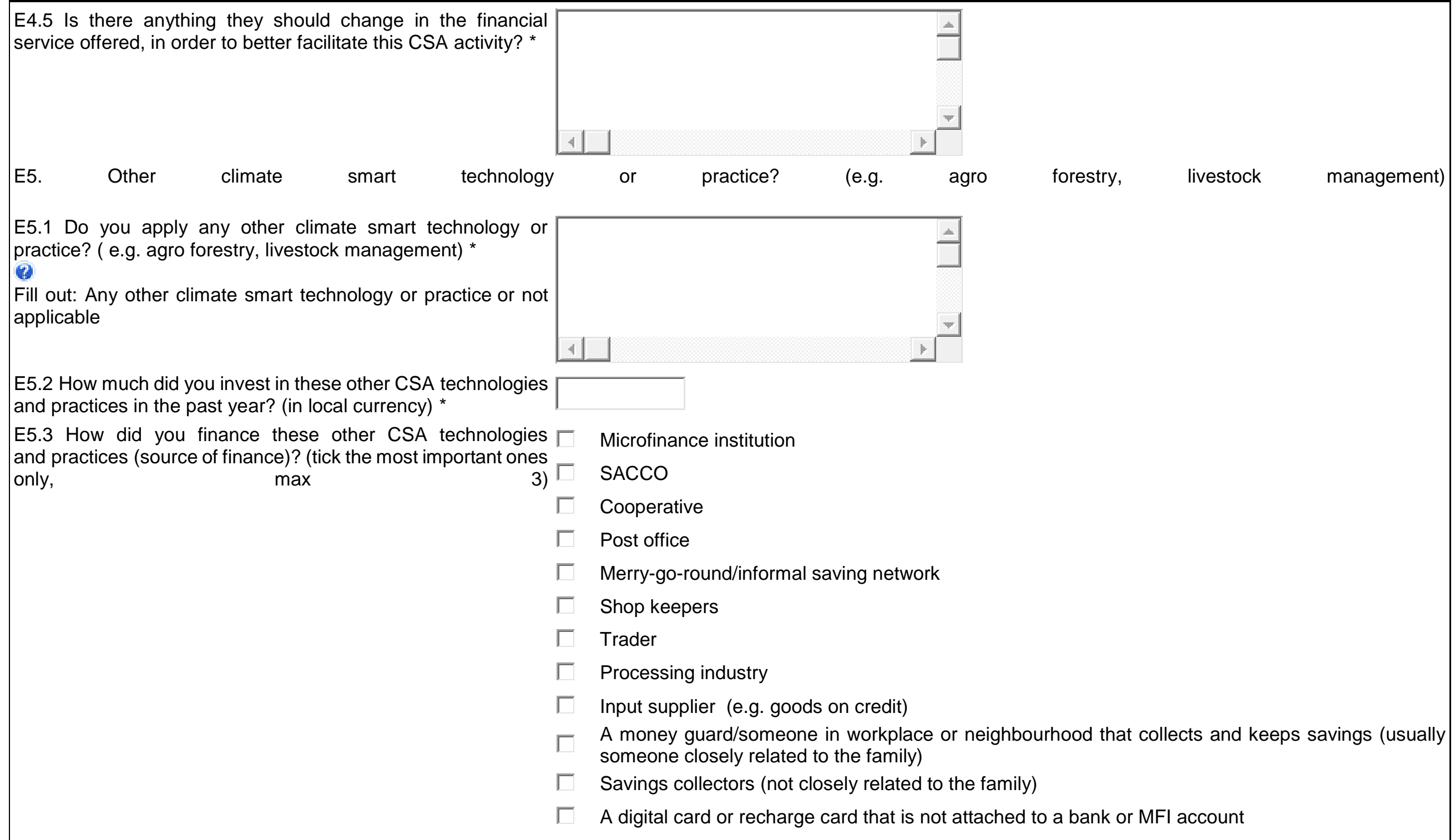




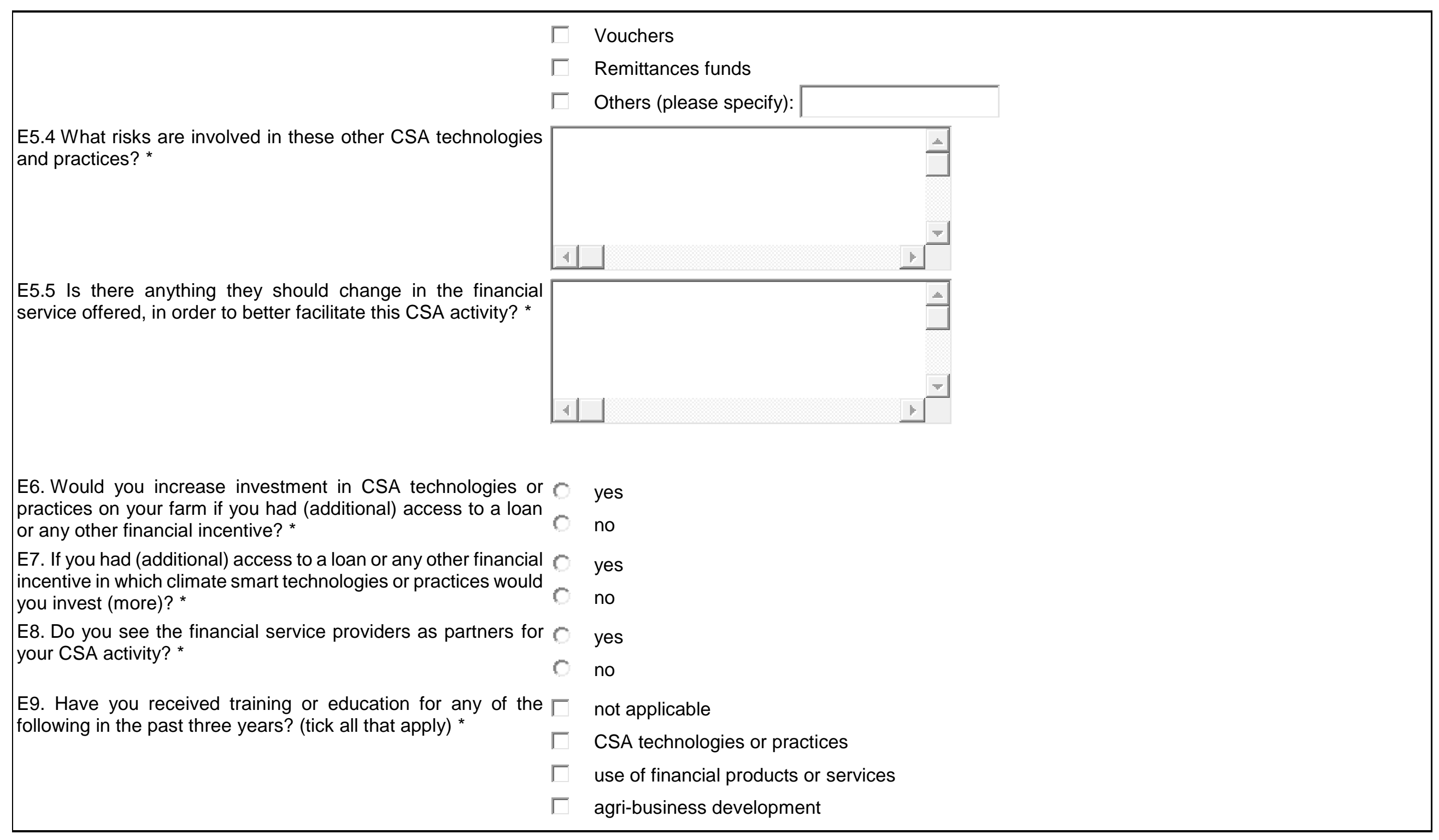


Agri business

Climate

Agriculture

Collateral

Financial product
Businesses involved in the production, trading and processing of agricultural

SmartClimate Smart Agriculture (CSA) is an integrative approach to address the interlinked challenges of food security and climate change that explicitly aims for three objectives:

- Sustainably increasing agricultural productivity, to support equitable increase in farm incomes, food security and development

- Adapting and building resilience of agricultural and food security systems to climate change at multiple levels

- Reducing greenhouse gases emissions from agriculture and/or increase carbon sequestration

Examples of climate smart agriculture technologies and practices include: zero tillage, residue management, direct dry seeded rice, nutrient management decision support tools, agroforestry, crop diversification, grassland restoration, manure management and climate information

services.

In lending agreements, collateral is a borrower's pledge of specific property to a lender, to secure repayment of a loan. The collateral serves as a lender's protection against a borrower's default, that is if they fail to repay

$$
\text { the }
$$

loan.

A financial product is a facility through which, or through the acquisition of which, a person or SME does one or more of the following: makes a financial investment, manages financial risk and/or makes non-cash payments. Examples of financial products include, banking (having a bank account), loans, micro credit, insurance), savings. 


\begin{tabular}{|c|c|}
\hline Financial service & $\begin{array}{l}\text { General term for all kinds of services around depositing and lending out } \\
\text { of money, management of capital funds and money transactions, and } \\
\text { buying and selling of financial risks. In the world of international financial } \\
\text { inclusion, financial services generally comprise credit and investments, } \\
\text { savings, insurance, and payment services. }\end{array}$ \\
\hline Financial institution & $\begin{array}{l}\text { A financial institution }(\mathrm{FI}) \text { is a company or organisation engaged in the } \\
\text { business of dealing with monetary transactions, such as deposits, loans, } \\
\begin{array}{lll}\text { investments } & \text { and } & \text { currency }\end{array} \text { exchange. }\end{array}$ \\
\hline $\begin{array}{l}\text { Informal } \\
\text { institution }\end{array}$ & $\begin{array}{l}\text { An informal financial institution provides a potentially wide range of } \\
\text { financial activities and services that take place beyond the scope of a } \\
\text { country's formalized financial institutions and lie outside financial sector } \\
\text { regulations. }\end{array}$ \\
\hline $\begin{array}{l}\text { Formal } \\
\text { institution }\end{array}$ & $\begin{array}{l}\text { A formal financial institution is a legal incorporated company or } \\
\text { organisation, operating within financial sector regulations. }\end{array}$ \\
\hline MFI & Institutions \\
\hline SACCO & Savings and Credit Cooperative Organizations \\
\hline SME & $\begin{array}{l}\text { Microenterprise-up to } 10 \text { employees, total assets of up to } \$ 10,000 \text { and } \\
\text { total annual sales of up to } \$ 100,000 \text {; small enterprise- up to } 50 \\
\text { employees, total assets and total sales of up to } \$ 3 \text { million; medium } \\
\text { enterprise- - up to } 300 \text { employees, total assets and total sales of up to } \\
\$ 15 \quad \text { million (SME Department, World Bank in: } \\
\text { http://siteresources.worldbank.org/DEC/Resources/84797- } \\
\text { 1114437274304/SME_globe.pdf) }\end{array}$ \\
\hline VSLA & Village Savings and Loan Association \\
\hline
\end{tabular}


Wageningen Environmental Research P.O. Box 47

6700 AA Wageningen

The Netherlands

T +31 (0)317480700

www.wur.nl/environmental-research

Wageningen Environmental Research Report

ISSN 1566-7197
The mission of Wageningen University and Research is "To explore the potential of nature to improve the quality of life". Under the banner Wageningen University \& Research, Wageningen University and the specialised research institutes of the Wageningen Research Foundation have joined forces in contributing to finding solutions to important questions in the domain of healthy food and living environment. With its roughly 30 branches, 5,000 employees and 10,000 students, Wageningen University \& Research is one of the leading organisations in its domain. The unique Wageningen approach lies in its integrated approach to issues and the collaboration between different disciplines.

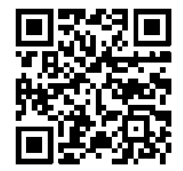

